DEVELOPMENT OF CONTAINER MATERIALS FOR LAMPRE APPLICATIONS 


\section{DISCLAIMER}

This report was prepared as an account of work sponsored by an agency of the United States Government. Neither the United States Government nor any agency Thereof, nor any of their employees, makes any warranty, express or implied, or assumes any legal liability or responsibility for the accuracy, completeness, or usefulness of any information, apparatus, product, or process disclosed, or represents that its use would not infringe privately owned rights. Reference herein to any specific commercial product, process, or service by trade name, trademark, manufacturer, or otherwise does not necessarily constitute or imply its endorsement, recommendation, or favoring by the United States Government or any agency thereof. The views and opinions of authors expressed herein do not necessarily state or reflect those of the United States Government or any agency thereof. 


\section{DISCLAIMER}

Portions of this document may be illegible in electronic image products. Images are produced from the best available original document. 


\section{LEGAL NOTICE}

This report was prepared as an account of Government sponsored work. Neither the United States, nor the Commission, nor any person acting on behalf of the Commission:

A. Makes any warranty or representation, expressed or implied, with respect to the occuracy, completeness, or usefulness of the information contained in this report, or that the use of any information, apparatus method, or process disclosed in this report may not infringe privately owned rights; or

B. Assumes any liabilities with respect to the use of, or for damages resulting from the use of any information, apparatus, method, or process disclosed in this report.

As used in the above, "person acting on behalf of the Commission" includes any employee or contractor of the Commission, or employee of such contractor, to the extent that such employee or contractor of the Commission, or employee of such controctor prepares, disseminates, or provides access to, any information pursuant to his employment or contract with the Com* mission, or his employment with such contractor.

Printed in USA

Price

$\$ 1.25$

Available from the Office of Technical Services

U. S. Department of Commerce

Washington 25. D. C. 
Report No. BMI- 1500

UC-25 Metals, Ceramics, and Materials (TID-4500, 16th Ed.)

Contract No. W-7405-eng-92

\section{DEVELOPMENT OF CONTAINER MATERIALS \\ FOR LAMPRE APPLICATIONS}

by

David C. Drennen

Merritt E. Langston

Charles J. Slunder

Joseph G. Dunleavy

A. M. Hall

February 14, 1961

BATTELLE MEMORIAL INSTITUTE

505 King Avenue

Columbus 1, Ohio 
ABSTRACT

INTRODUCTION

PREPARATION OF EXPERIMENTAL ALLOYS . . . . . . . . . . . . . . $\quad 2$

Alloy Selection . . . . . . . . . . . . . . . . . . . . . . 2

Materials

Arc Melting and Casting.

Equipment .

Melting Procedure

Radiography

Sectioning

Fabrication

Cleaning

Pressing

Machining .

Cold Rolling

Vacuum Annealing.

Intermediate Annealing

Final Annealing

EVALUATIONAL PROCEDURES . . . . . . . . . . . . . . . . . ..

Surface Tests for Iron . . . . . . . . . . . . . . . . . . . . 13

Chemical Analyses . . . . . . . . . . . . . . . . . . . 14

Metallography . . . . . . . . . . . . . . . . . . . . . . 14

Hardness Measurements . . . . . . . . . . . . . . . . . . 15

Tensile Testing . . . . . . . . . . . . . . . . . . . . . . . 15

EXPERIMENTAL RESULTS AND DISCUSSION . . . . . . . . . . . . . $\quad 16$

Arc-Casting Behavior . . . . . . . . . . . . . . . . . . . . 16

Fabrication Behavior . . . . . . . . . . . . . . . . . . . . 16

Annealing Studies . . . . . . . . . . . . . . . . . . . . . . 16

Chemical Analyses. . . . . . . . . . . . . . . . . . . 22

Microstructure . . . . . . . . . . . . . . . . . . . . . . 27

Hardness . . . . . . . . . . . . . . . . . . . . . . 35

Tensile Properties. . . . . . . . . . . . . . . . . . . . . . 39

Corrosion Testing . . . . . . . . . . . . . . . . . . . . . . . 45

CONCLUSIONS

ACKNOW LEDGMENT . . . . . . . . . . . . . . . . . . . . . . . . . . . . 46

REFERENCES . . . . . . . . . . . . . . . . . . . . . . . . . . . . . . . 


\title{
DEVELOPMENT OF CONTAINER MATERIALS FOR LAMPRE APPLICATIONS
}

\author{
David C. Drennen, Merritt E. Langston, Charles J. Slunder, \\ Joseph G. Dunleavy, and A. M. Hall
}

\begin{abstract}
Some 83 high-purity binary tantalum-base alloys were prepared as candidate materials of construction for the Los Alamos Molten Plutonium Reactor Experiment (LAMPRE). The alloys were evaluated metallurgically at Battelle and then forwarded to LASL for evaluation in the plutonium-alloy fuel mixtures.

Although the corrosion tests are not complete, preliminary data indicate that good resistance to attack by the fuels can be obtained by alloying tantalum. Alloys containing additions of rhenium and tungsten have shown good corrosion resistance in polythermal $(1382$ to $1022 \mathrm{~F})$ tilting-furnace exposures. Tantalumyttrium alloys also have displayed good corrosion resistance, even though the yttrium apparently was lost during arc melting. Most of the alloys, including those which showed good corrosion resistance, were amenable to arc melting and casting and fabrication at room temperature.
\end{abstract}

\section{INTRODUCTION}

Tantalum has been considered for the reactor-core structural material in the Los Alamos Molten Plutonium Reactor Experiment (LAMPRE) because of its resistance to attack by plutonium-alloy fuels, its good forming properties at room temperature, and its possession of adequate strength at the proposed operating temperature of $1200 \mathrm{~F}$. However, data obtained at LASL indicated that the resistance of commercial grades of tantalum to corrosion by the molten plutonium-alloy fuel mixtures was inconsistent and had to be improved to eliminate (1) intergranular corrosion, which seems to be affected by the degree of cleanliness in the grain boundaries, and (2) general surface roughening. (1) Although sufficient data are not available to determine precisely the chemical phenomena associated with the first effect, it is believed that a high oxygen content in commercial tantalum contributes to the second type of attack.

To assist LASL in the LAMPRE project, a research program directed toward the development of container materials suitable for use in LAMPRE service was undertaken at Battelle Memorial Institute. The objective of the program was to develop a tantalumbase alloy which would be acceptable with respect to corrosion resistance in the plutonium-alloy fuel mixtures. A satisfactory combination of elevated-temperature strength, ductility, and weldability was desired, but it was not imperative that the alloy be superior to tantalum except from a corrosion standpoint.

(1) References are at end of report. 
The basic precept of the research program was that only a high-purity material held maximum promise from the viewpoint of compatibility with the plutonium-alloy fuels. The program involved (1) selection of alloy systems, (2) preparation of materials as high-purity alloys, (3) evaluation of the alloys with reference to purity, homogeneity, soundness, fabricability, hardness, and strength, and (4) preparation of specimens for fuel-corrosion tests at LASL.

\section{PREPARATION OF EXPERIMENTAL ALLOYS}

\section{Alloy Selection}

Because of the large number of alloy systems to be investigated, the addition of alloying elements to tantalum was limited to a maximum of $6 \mathrm{w} / \mathrm{o}$. For the most part, the alloying elements were of two general types. One consisted of elements which were expected to form solid-solution alloys of tantalum. Single-phase alloys were considered preferable because the presence of a secondary phase in the alloy might detract from corrosion resistance. The other consisted of elements which were added to serve primarily as scavengers of interstitial impurities, which might be responsible for certain types of corrosion in tantalum. The expected mechanisms operative in the alloys containing scavenger elements were (1) the formation of a more stable carbide, hydride, nitride, or oxide in the alloy, and/or (2) the removal of interstitial impurities from the tantalum during melting.

The tantalum-tungsten system was selected first for investigation for several reasons:

(1) Tungsten is known to resist attack by the plutonium-alloy fuels. (1)

(2) Tungsten forms a complete series of solid-solution alloys with tantalum. (2)

(3) Tungsten is known to increase the strength of tantalum by solid-solution hardening. (3)

(4) The tantalum-tungsten system was of interest because of the transmutation of tantalum to tungsten upon irradiation.

The other elements alloyed with tantalum were expected to show considerable solid solubility. These included hafnium, rhenium, titanium, yttrium, and zirconium.

Elements which were added for the purpose of acting as scavengers of interstitial impurities were aluminum, beryllium, carbon, cerium, lanthanum, scandium, thorium, titanium, uranium, yttrium, and zirconium.

Alloys containing additions of either boron, iron, or silicon were of special interest to Los Alamos personnel and were prepared at their request. 
Some 83 unalloyed tantalum and binary tantalum-base alloys, which were divided into four series as indicated in Table 13, were prepared for plutonium-alloy-fuel corrosion tests at LASL. The first series of alloys included a large number of unalloyed tantalum buttons, for the purpose of evaluating the arc-melting operation. In addition, subsequent series of alloys contained at least one unalloyed tantalum button for control purposes.

\section{Materials}

All of the unalloyed tantalum and tantalum-base alloys prepared for this study were made from various lots of ultrahigh-purity electron-beam-melted tantalum purchased from the Temescal Metallurgical Corporation either by Battelle or by LASL. The tantalum processed by Battelle originally had been capacitor-grade scrap which was purified to the analyses indicated in Table 1 . The tantalum sheet obtained from LASL had been high-purity powder, provided by the National Research Corporation, which was also purified by electron-beam melting to the purity level indicated in Table 1.

LASL began supplying tantalum to Battelle after the first two series of alloys had been prepared. The purpose was to provide both the LASL and the Battelle program with the same base material and, thus, eliminate it as a factor in evaluating the corrosion behavior of LASL and Battelle alloys. Tantalum was received from LASL in the form of 0. 030-in. -thick sheet scrap obtained from punching out blanks for test thimbles.

Alloying additions of the highest purity available were used in preparing the tantalum alloys. Chemical analyses were performed on some of the alloying additions as indicated in Table 2.

\section{Arc Melting and Casting}

Preliminary studies had been conducted at the end of a previous program for LASL to establish a suitable basic arc-melting procedure with respect to (1) maintaining the high-purity levels of the melting stock, (2) obtaining homogeneous alloys, (3) obtaining sound button specimens, (4) determining the optimum button weight, and (5) obtaining information on alloy-addition recoveries. From these preliminary studies, a basic melting procedure was developed. Also, the chemical analyses and hardness data obtained therefrom indicated that arc melting under conditions to be discussed later, had no significant effect on the purity of unalloyed tantalum and tantalum alloys, unless difficulties were encountered during melting.

\section{Equipment}

Button specimens, weighing from 100 to $250 \mathrm{~g}$, were prepared by arc melting in a flip-type arc furnace with a tungsten electrode and a water-cooled copper crucible under $1 / 3 \mathrm{~atm}$ of AEC helium. The specially designed crucible had a small cavity located adjacent to the casting cavity to hold a small charge of either zirconium or tantalum, for the purpose of gettering residual impurities in the furnace. 
TABLE 1. ANALYSES AND HARDNESS OF HIGH-PURITY ELECTRON-BEAM-MELTED TANTALUM USED AS MELTING STOCK

\begin{tabular}{|c|c|c|c|c|c|c|c|c|c|c|c|c|}
\hline \multirow[b]{2}{*}{ Lot } & \multirow{2}{*}{$\begin{array}{l}\text { Alloy Series in } \\
\text { Which Used }\end{array}$} & \multirow{2}{*}{$\begin{array}{l}\text { Hardness, } \\
\text { VHN }\end{array}$} & \multicolumn{10}{|c|}{ Analyses, ppm } \\
\hline & & & C & $\mathrm{H}_{2}$ & $\mathrm{~N}_{2}$ & $\mathrm{O}_{2}$ & W & $\mathrm{Nb}$ & S1 & $\mathrm{Cu}$ & $\mathrm{Fe}$ & $\mathrm{Z}_{\mathrm{r}}$ \\
\hline B9269-1 & 1,2 & 92 & $<10$ & 1.7 & 20 & 11 & $<50$ & 300 & 10 & 15 & 7 & $<10$ \\
\hline В9269-2 & 2 & 90 & 10 & 0.4 & 10 & 11 & $<50$ & 100 & $<10$ & 5 & 30 & $<10$ \\
\hline LASL-1 & 3 & 91 & 10 & 0.3 & $<10$ & 46 & $<100$ & 50 & $<10$ & 10 & 3 & $<10$ \\
\hline LASL-2 & 3 & -- & 20 & 1.0 & 20 & 14 & 200 & $<10$ & $<10$ & 100 & $<3$ & $<10$ \\
\hline LASL-3 & 4 &.- & 10 & 0.20 & 20 & 14.5 & 50 & (a) & 5 & 10 & 8 & $<10$ \\
\hline LASL-4 & 4 & -- & 10 & $<0.6$ & 30 & 8 & $<100$ & (a) & 3 & $<0.5$ & 1.0 & $<10$ \\
\hline
\end{tabular}

(a) Not detected.

TABLE 2. ANALYSES OF ALLOYING ELEMENTS USED TO MAKE HIGH-PURITY TANTALUM-BASE ALLOYS

\begin{tabular}{|c|c|c|c|c|c|c|c|c|c|c|c|c|c|c|c|}
\hline \multirow[b]{2}{*}{ Element } & \multirow{2}{*}{$\begin{array}{c}\text { Lot } \\
\text { Number }\end{array}$} & \multirow{2}{*}{$\begin{array}{c}\text { Supplier's } \\
\text { Analysis } \\
\text { w/o }\end{array}$} & \multirow{2}{*}{$\begin{array}{c}\text { Alloy Series } \\
\text { in Which } \\
\text { Used }\end{array}$} & \multirow[b]{2}{*}{ Form } & \multicolumn{11}{|c|}{ Analyses, ppm } \\
\hline & & & & & C & $\mathrm{H}_{2}$ & $\mathrm{~N}_{2}$ & $\mathrm{O}_{2}$ & $\mathrm{~W}$ & $\mathrm{Nb}$ & Si & $\mathrm{Cu}$ & $\mathrm{Fe}$ & $\mathrm{Zr}$ & $\mathrm{Hf}$ \\
\hline Al & Al-1 & 99.99 & 4 & Briquette & -- & $-\infty$ & -- & -- & -- & -- & 10 & 20 & 10 & -- & - \\
\hline B & $B-1$ & 99.14 & 4 & Powder & - & -- & -- & -- & -- & $\cdots$ & - & -- & $\cdots$ & -- & -- \\
\hline $\mathrm{Be}$ & $\mathrm{Be}-1$ & $\cdots$ & 4 & Suntered balls & 1300 & 210 & $\begin{array}{r}166- \\
280\end{array}$ & 773 & $<50$ & $<200$ & 1000 & 20 & 1500 & 50 & -- \\
\hline C & $C-1$ & -- & 2 & $\begin{array}{l}\text { Spectrographic- } \\
\text { grade rod }\end{array}$ & -- & -- & -- & - & -- & -- & $\cdots$ & - & - & -- & - \\
\hline $\mathrm{Ce}$ & D6906-2 & 99.9 & 4 & Ingot & -- & $\cdots$ & - & -- & -- & -- & -- & -- & -- & -- & -- \\
\hline $\mathrm{Fe}$ & $\mathrm{Fe}-1$ & -- & 4 & Ingot & 10 & $<0.1$ & $<2$ & 15 & $<10$ & $\ldots$ & 10 & 2 & -- & $<0.5$ & -- \\
\hline $\mathrm{Hf}$ & $\mathrm{Hf}-1$ & - & 3 & Strip & 10 & 17 & 20 & 1020 & 3000 & -- & 30 & 30 & 250 & 8000 & -- \\
\hline $\mathrm{Hf}$ & E3873 & -- & 4 & Crystal bar & 300 & -- & 90 & -- & (a) & -- & - & -- & -- & 1300 & -- \\
\hline La & D7656 & $\begin{array}{l}99.5 \\
\text { (mun) }\end{array}$ & 4 & Ingot & -- & - & -- & - & -- & - & - & - & -- & -- & - \\
\hline $\operatorname{Re}$ & $\mathrm{C} 2295$ & -- & 2 & Sintered strip & 40 & 6 & $<10$ & 55 & -- & $<50$ & $<10$ & $<5$ & 5 & $<50$ & -- \\
\hline Sc & D6906-1 & $99+$ & 4 & Wafer & $-\rightarrow$ & $=-$ & - & - & -- & -- & -- & - & -- & -- & -- \\
\hline Si & $S_{1-1}$ & - & 4 & Single crystal & -- & -- & -- & -- & - & -- & - & -- & -- & - &.- \\
\hline Th & D2974 & -- & 3,4 & Crystal bar & $<10$ & 27 & $<10$ & 231 & $<120$ & (a) & $<10$ & 2 & 10 & (a) & -- \\
\hline$T_{1}$ & D2975-1 & -- & 3,4 & Crystal bar & $<10$ & $\begin{array}{r}300- \\
326\end{array}$ & $<10$ & $\begin{array}{r}227- \\
238\end{array}$ & $<50$ & $<100$ & 100 & 40 & 50 & $<30$ & -. \\
\hline $\mathrm{U}$ & $\mathrm{U}-1$ & 99.999 & 4 & Biscuit & -- & -- & - & $\cdots$ & -- & -. & - & -- & - & - & - \\
\hline W & C3043-1 & - & 1 & Undoped rod & $<10$ & 0.6 & 10 & 8 & -- & -- & 100 & 10 & 5 & $<10$ & -- \\
\hline W & C3043-2 & 99.999 & 3 & $\begin{array}{l}\text { Zone-refined } \\
\text { rod }\end{array}$ & -- & - & -- & -- & -- & -- & - & -- & -- & -- & - \\
\hline $\mathbf{Y}$ & $Y-1$ & -- & $2,3,4$ & Ingot & 110 & 5.2 & 80 & 2670 & -- & $<50$ & 10 & $<10$ & $<10$ & 10 & -- \\
\hline $\mathrm{Z}_{\mathbf{r}}$ & $\mathrm{Zr}-2$ & - & 3,4 & Crystal bar & 60 & 54 & 10 & 340 & 500 & $<300$ & 200 & 20 & 300 & - & -- \\
\hline
\end{tabular}

(a) Not detected. 


\section{Melting Procedure}

Prior to each melting, the furnace was cleaned as follows:

(1) Swabbed with paper tissues

(2) Vacuumed with sweeper

(3) Wire brushed

(4) Casting cavity abraded with silicon carbide abrasive disks

(5) Swabbed again with paper tissue

(6) Vacuumed again with sweeper.

The getter material, which was changed periodically, and the charge, which usually consisted of small sheared pieces of tantalum and the alloy addition, were then placed in the proper cavities in the crucible. The alloy addition was placed between two layers of tantalum stock to prevent vaporization of the alloying element when the arc was started.

The basic melting cycle for 100 to $150-\mathrm{g}$ buttons was as follows:

(1) The furnace was charged and evacuated to an operating pressure of $10 \mu$ or less.

(2) The system was flushed three times with AEC helium, and pumped down to the operating pressure after each flushing.

(3) With the cold water flowing around the crucible and the lowest pressure obtained, the leak rate was checked and was limited to a maximum of $2 \mu$ per min.

(4) The furnace was evacuated again to the lowest pressure possible.

(5) The vacuum valve was closed and $1 / 3$ atm of helium was introduced.

(6) The arc was started on the getter charge and held for 5 to 10 sec and then swung over to the charge on the first melt after the furnace was closed. On subsequent melts the arc was started directly on the charge if the highfrequency arc starter was used; if the arc starter was not used, the arc was again initiated on the getter by touching it.

(7) Each 100 to $150-\mathrm{g}$ alloy button was melted at least six times at $30 \mathrm{v}, 800 \mathrm{amp}$ for $30 \mathrm{sec}$; buttons were flipped after each melt by rapping on the bottom of the furnace.

(8) The buttons were cooled $3 \mathrm{~min}$ before removal from the furnace. 
For buttons weighing 200 and $250 \mathrm{~g}$ it was necessary, due to equipment limitations, to first prepare two 100- and $125-\mathrm{g}$ buttons according to the procedure above. These were then placed one on top of the other and consolidated into one large button. The first six steps of the melting-cycle procedure used for the small buttons were also used in the consolidation. However, the remainder was different and the best procedure was as follows:

(1-6) The procedure was the same as for the 100 to $150-\mathrm{g}$ buttons.

(7) The buttons were melted four times at $30 \mathrm{v}, 800 \mathrm{amp}$ for $60 \mathrm{sec}$. The buttons were flipped after the first three meltings. At the end of the fourth melting, the power was reduced to $30 \mathrm{v}, 400 \mathrm{amp}$ for about $30 \mathrm{sec}$ to smooth the surface. The buttons were then flipped and melted again at $30 \mathrm{v}, 400 \mathrm{amp}$ for about $60 \mathrm{sec}$.

(8) The buttons were cooled $8 \mathrm{~min}$ before removal from the furnace.

A summary of the arc melting of the unalloyed tantalum and tantalum-base alloys; according to alloy series (see Table 13), is given in Table 3. Figure 1 shows the surface of a typical arc-cast 200-g button, in this case, of unalloyed tantalum.

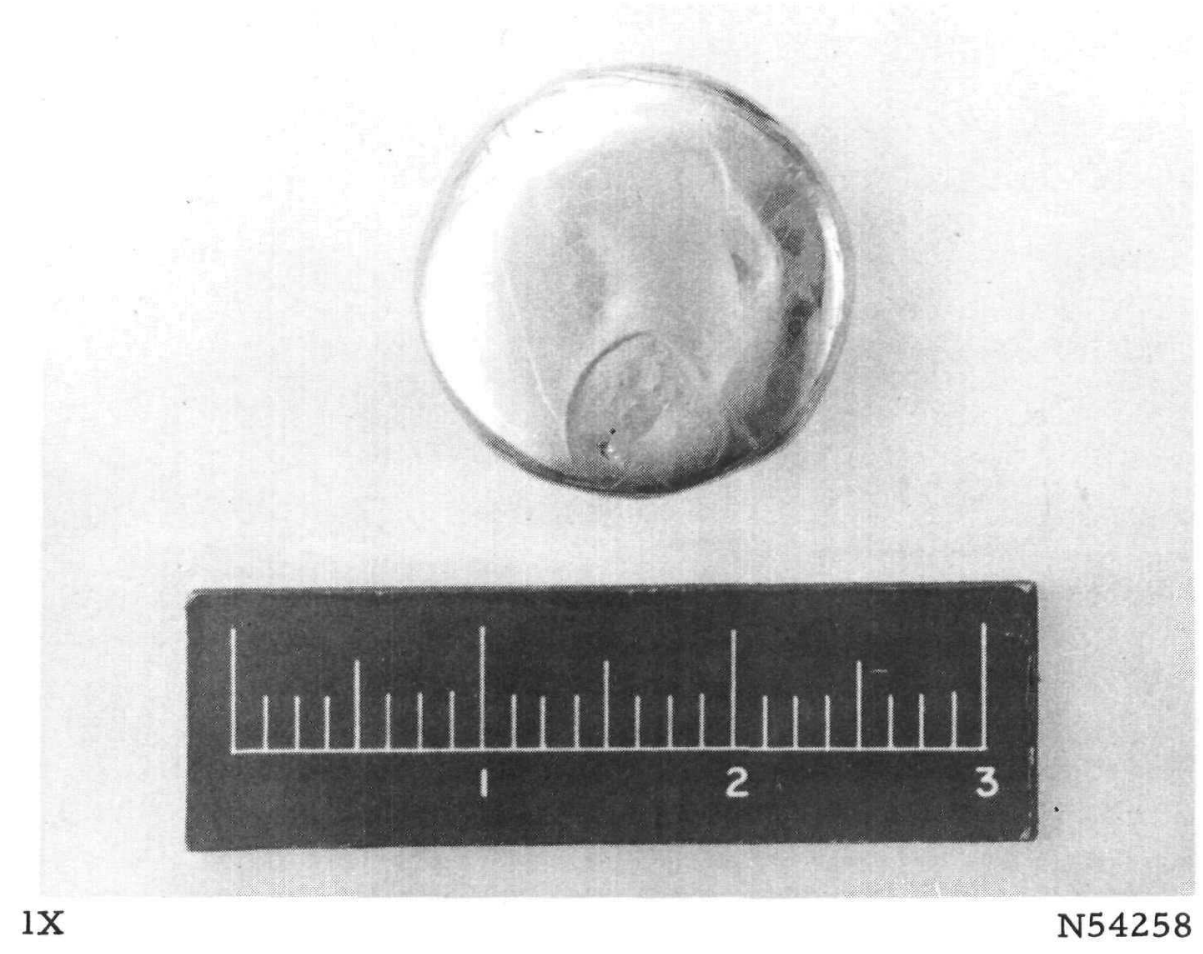

\section{FIGURE 1. TYPICAL ARC-CAST 200-G BUTTON OF UNALLOYED TANTALUM}

Zirconium was used as the gettering material in the arc melting of the unalloyed tantalum buttons of the first series. However, in an attempt to eliminate foreign materials in the furnace during melting, the zirconium was replaced by tantalum during the preparation of materials thereafter. 
After the first series of alloys had been prepared, it was believed that a zirconium liner in the furnace might improve the purity of the alloys by gettering gaseous impurities during melting. Therefore, a 1/16-in. -thick liner was fitted to the inside of the crucible above the casting cavity. However, later chemical analyses, which are contained in Table 11, on the alloys of the second series failed to show any improvement in the purity levels. Because of the apparent ineffectiveness and also the operating problems associated with the zirconium liner, it was decided to discontinue its use.

At the initiation of arc melting of the fourth series of alloys, difficulty was encountered from severe erosion of the tungsten electrode which resulted in contamination of the alloys with tungsten. Melting was discontinued temporarily to determine the source of trouble and to eliminate it if possible. It was believed that the electrode material might be a factor in the unusual tip erosion. Also, it was suggested that the erosion problem might be modified by conditioning the electrode with yttrium. In order to investigate these possibilities, the following series of arc-melting experiments was conducted:

(1) Unalloyed tantalum was melted with electrodes prepared from normal sintered, forged, and thoriated tungsten.

(2) Unalloyed tantalum was melted with the three types of electrodes, but with $0.2 \mathrm{w} / \mathrm{o}$ yttrium placed on top of the tantalum charge.

(3) Unalloyed tantalum was melted with the three types of electrodes, but the electrodes were "conditioned" by having been spattered with yttrium from the melting done in (2).

The results of these tests indicated that (1) an addition of $0.2 \mathrm{w} / 0$ yttrium to the tantalum charge was far more than was needed to eliminate tip loss, (2) tip loss could be significantly reduced by conditioning the tip with yttrium as in (3) above, and (3) tip loss for unconditioned electrodes increased in the order: thoriated tungsten, forged tungsten, and normal sintered tungsten. The loss for the latter was almost eight times that of the thoriated tungsten. As a result of this finding, yttrium was either added to some of the tantalum and tantalum-base alloy charges or an electrode conditioned previously with yttrium was used. Some of the alloying elements of the fourth series were similar to yttrium chemically and, therefore, were expected to behave like yttrium in controlling tip loss. In these cases, yttrium was not used. In other cases, yttrium was not added because there were indications of a possible interaction between the alloying element and the yttrium. Table 4 contains a list of the materials in which yttrium was either added to the charge or the tip was previously conditioned by melting a charge that had yttrium added to it. In these cases, the yttrium addition was $0.10 \mathrm{w} / 0$ rather than the $0.2 \mathrm{w} / \mathrm{o}$ used in the tip-loss control experiments, because the latter had been found to be much more than necessary.

\section{Radiog raphy}

The soundness of the arc-cast buttons was determined by means of radiographic examination. The radiographic negatives were studied, and if a button was sound or contained voids that were not expected to prevent the preparation of good quality strip material, the button was processed. However, if the button contained too many voids or a fairly large void, the button was remelted. 
TABLE 3. SUMMARY OF ARC-MELTING PROCEDURES FOR THE PREPARATION OF TANTALUM AND TANTALUMBASE ALLOYS

\begin{tabular}{|c|c|c|c|c|}
\hline \multirow{2}{*}{$\begin{array}{l}\text { Alloy } \\
\text { Series }\end{array}$} & \multicolumn{2}{|c|}{ Unalloyed T antalum } & \multicolumn{2}{|c|}{ Tantalum-Base Alloys } \\
\hline & Button Weight, 8 & Number of Melts & Button Weight, $\mathrm{g}$ & Number of Melts \\
\hline \multirow[t]{2}{*}{1} & 100 & 2 & 100 & 6 \\
\hline & $200^{(a)}$ & 2 & $200(a)$ & 2 \\
\hline \multirow[t]{3}{*}{2} & 150 & 7 & 125 & 6 \\
\hline & & & 150 & 7 \\
\hline & & & 250 (b) & 2 \\
\hline \multirow[t]{3}{*}{3} & 150 & 7 & 125 & 6 \\
\hline & & & 150 & 7 \\
\hline & & & 250 (b) & 4 \\
\hline \multirow[t]{3}{*}{4} & 100 & 6 & 100 & $3(c)$ \\
\hline & $200(a)$ & 4-5 & 100 & 6 \\
\hline & & & 200 & $4-5$ \\
\hline
\end{tabular}

(a) Two $100 \mathrm{gg}$ buttons were consolidated to form one $200 \mathrm{mg}$ button.

(b) Two $125 \mathrm{-g}$ buttons were consolidated to form one $250 \mathrm{-g}$ button.

(c) This represents the melting of the tantalum-yttrium alloys (109 and 110), in which the objective was to retain yttrium rather than to obtain homogeneity.

TABLE 4. TANTALUM AND TANTALUM-BASE ALLOYS ARC MELTED WITH YTTRIUM OR YTTRIUM-CONDITIONED TUNGSTEN ELECTRODES

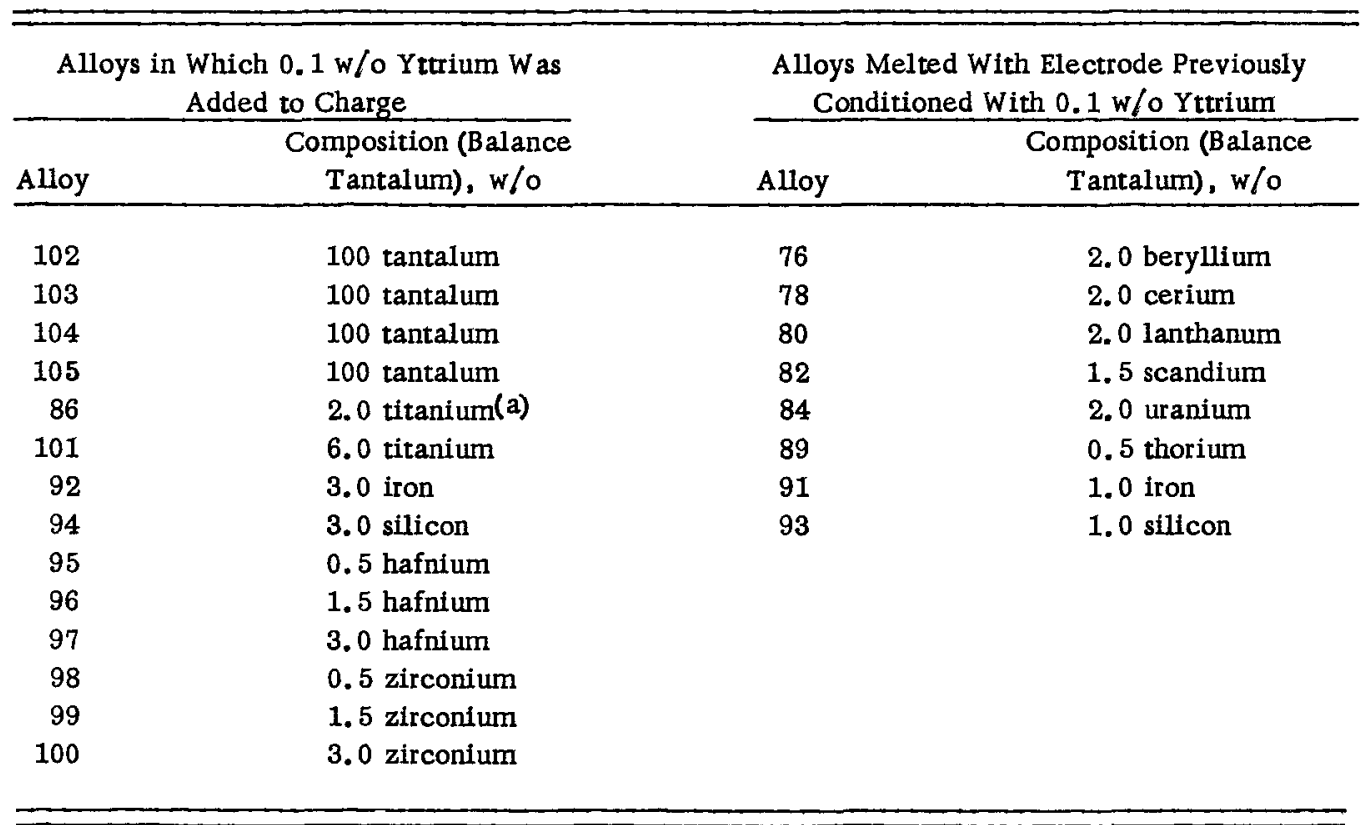

(a) Only $0.05 \mathrm{w} / \mathrm{o}$ yttrium was added to this alloy during the consolidation of the two $100 \mathrm{mg}$ buttons. 


\section{Sectioning}

The arc-cast buttons were sectioned to provide specimens for metallographic examination and hardness measurements, chemical analyses, and stock for processing to strip. Two sections about $1 / 4$ in. wide were sawed from opposite edges of a button, thus leaving the bulk of the material for fabrication. Care was taken to prevent overheating during sawing, which could have resulted in contamination of the material by oxygen, hydrogen, and nitrogen from the air.

\section{Fabrication}

The ultimate objective was to fabricate the sectioned arc-cast buttons to 0.030-in.thick strip without introducing any impurities into the materials and in such a manner that a fine-grained structure could be obtained after annealing. As time progressed, procedures were improved with these two objectives in mind.

\section{Cleaning}

Special cleaning procedures were employed ( 1 ) between fabrication steps to remove surface contamination picked up during processing and (2) to prepare the alloys for vacuum annealing. The general cleaning procedure was as follows:

(1) Wash in a boiling Alconox (wetting agent) solution (about $10 \mathrm{~g}$ of Alconox per liter) for $20 \mathrm{~min}(4)$

(2) Rinse with water and cp acetone

(3) Pickle in aqua regia (2 parts $\mathrm{HCl}-1$ part $\mathrm{HNO}_{3}$ ) for $20 \mathrm{~min}$

(4) Rinse with water, alcohol, and then cp acetone.

There were some variations used in the cleaning procedure from time to time. For example, in the first series of alloys, the materials were pickled in a "Bright Dip" solution (55 parts $\mathrm{H}_{2} \mathrm{SO}_{4}-25$ parts $\mathrm{HNO}_{3}-20$ parts $\mathrm{Hf}$ ) rather than in aqua regia. However, tests conducted at LASL indicated that exposures greater than $15 \mathrm{sec}$ in the Bright Dip solution resulted in gas pickup in the tantalum. (1) On the other hand, exposures up to $30 \mathrm{~min}$ in aqua regia did not cause any contamination. As a result of their finding, LASL advised against use of the Bright Dip solution for exposures greater than a few seconds. The cold-rolled materials of the third series were given the general cleaning treatment indicated previously plus a 5-sec immersion in the Bright Dip solution, for the purpose of improving the surface finish.

\section{$\underline{\text { Pressing }}$}

The arc-cast buttons were pressed to break up the large-grained cast structure, and to flatten the convex surfaces in order to facilitate machining and to cut down 
material losses. The pressing was carried out on a 700-ton hydraulic press. The buttons were placed between two hardened steel plates that had been cleaned thoroughly with acetone and coated with melted Palma Shield lubricant (an artificial substitute for palm oil) to prevent iron pickup. The buttons were pressed at room temperature at an approximate rate of 8 in. per min. In general, a load of about 100 to 150 tons was required to press the buttons from a thickness of about $1 / 2$ to $1 / 4 \mathrm{in}$.

Table 5 contains a tabulation of the thicknesses of the various size buttons in each alloy series after pressing and the amount of reduction. The per cent reduction is not accurate since the buttons had a convex surface to begin with. The figures merely serve as an indication of the amount of reduction given the buttons.

TABLE 5. THICKNESS AND PER CENT REDUCTION OF TANTALUM AND TANTALUM ALLOYS ACCORDING TO ALLOY SERIES AFTER PRESSING

\begin{tabular}{|c|c|c|c|c|c|c|c|c|}
\hline \multirow[b]{2}{*}{$\begin{array}{l}\text { Alloy } \\
\text { Series }\end{array}$} & \multicolumn{2}{|c|}{$100-\mathrm{g}$ Buttons } & \multicolumn{2}{|c|}{ 150-g Buttons } & \multicolumn{2}{|c|}{$200-g$ Buttons } & \multicolumn{2}{|c|}{ 250-g Buttons } \\
\hline & $\begin{array}{c}\text { Thickness, } \\
\text { in. }\end{array}$ & $\begin{array}{l}\text { Reduction, } \\
\text { per cent }\end{array}$ & $\begin{array}{c}\text { Thickness, } \\
\text { in. }\end{array}$ & $\begin{array}{l}\text { Reduction, } \\
\text { per cent }\end{array}$ & $\begin{array}{c}\text { Thickness, } \\
\text { in. }\end{array}$ & $\begin{array}{c}\text { Reduction, } \\
\text { per cent }\end{array}$ & $\begin{array}{c}\text { Thickness, } \\
\text { in. }\end{array}$ & $\begin{array}{l}\text { Reduction, } \\
\text { per cent }\end{array}$ \\
\hline 1 & \multicolumn{8}{|c|}{ Buttons were not pressed } \\
\hline 2 & $\ldots$ & -- & $0.160-0.215$ & $28-46$ & - & -- & $0.200-0.255$ & $33-65$ \\
\hline 3 & - & -- & $0.208-0.270$ & $19-45$ & $-\infty$ & $\ldots$ & $0.274-0.292$ & $22-37$ \\
\hline 4 & $0.170-0.202$ & $19-28$ & -- & $=$ & $0.227-0.266$ & $19-46$ & -- & -- \\
\hline
\end{tabular}

\section{$\underline{\text { Machining }}$}

All of the arc-cast buttons were machined to remove surface contamination picked up during melting and pressing and to improve the surface finish for subsequent cold rolling. To obtain the desired smooth finish on the buttons a special high-speed tool was developed in a brief machining study. This tool was used with a hydraulic shaper having an automatic clapper. Machining conditions were: (1) 60-stroke-per-min surface speed, (2) 0.003 to $0.005-$ in. feed, and (3) 0.005-in. cut. A water-soluble oil was used as a spray-mist lubricant during machining. The edges of a button, where sections had been removed for various evaluations, were machined parallel to facilitate easier chucking in the shaper. Then each face of a button was machined with a minimum amount of material removed. However, not less than 0.010 in. was removed from each face. Table 6 lists the thicknesses of the alloys by series after being machined.

TABLE 6. THICKNESSES OF TANTALUM AND TANTALUM-BASE ALLOYS (BY SERIES) AFTER MACHINING

\begin{tabular}{|c|c|c|c|c|}
\hline \multirow[b]{2}{*}{ Alloy Series } & \multicolumn{4}{|c|}{ Thickness, in., of Button Size Indicated } \\
\hline & $100 \mathrm{G}$ & $150 \mathrm{G}$ & $200 \mathrm{G}$ & $250 \mathrm{G}$ \\
\hline 1 & -- & -- & $0.229-0.339$ & -- \\
\hline 2 & - & $0.146-0.196$ & $-\infty$ & $0.160-0.205$ \\
\hline 3 & $-\ldots$ & $0.194-0.261$ & $\cdots$ & $0.254-0.272$ \\
\hline 4 & $0.139-0.189$ & $-\infty$ & $0.211-0.255$ & - \\
\hline
\end{tabular}


All of the alloys machined very well. In fact, the surfaces were generally so smooth that large grains were visible with the naked eye.

\section{Cold Rolling}

With the exception of the first series of alloys which were rolled directly without intermediate annealing to 0.030-in. -thick strip, the alloys we re taken through two rolling steps. The first step consisted of rolling the machined alloy buttons to thicknesses ranging from about 0.150 to $0.200 \mathrm{in.}$, followed by stress relief or intermediate vacuum annealing. Then, after the vacuum-annealing treatment, the second rolling step was to reduce the materials to 0.030 -in. -thick strip. The cold-rolled strip was used for (1) providing LASL with cold-rolled specimens for corrosion testing, (2) conducting annealing studies, and (3) providing material for vacuum annealing.

The alloys were rolled on an 8 by 12-in. mill using flat rolls. The rolls were cleaned thoroughly with acetone and then coated with melted Palma Shield lubricant to prevent iron pickup. (4) The surfaces of the alloys were also coated with the melted lubricant prior to each pass. A nominal reduction of 10 per cent was taken per pass.

Significant changes were made in the rolling procedure from one series of alloys to the next. These changes were made for the purpose of obtaining the desired microstructure in the 0.030-in. annealed material. Therefore, the rolling procedures are discussed in greater detail in the following paragraphs.

The alloys of the first series were rolled in one direction to 0.030 -in. strip after the machining operation. A total reduction of 90 per cent was made. Work-hardening effects were studied and are discussed later.

Alloys in the second series were alternately cross rolled and rolled lengthwise to a thickness of from 0.163 to 0.193 in. with total reductions up to 15 per cent. Then, the alloys were given an intermediate anneal to relieve stresses. Finally, the alloys were unidirectionally (lengthwise) cold rolled to 0.030-in. strip with total reductions of from 80 to 85 per cent.

The machined alloy buttons of the third series were unidirectionally (lengthwise) cold rolled to a thickness of from 0.142 to 0.148 in. with total reductions of from 25 to 47 per cent. After a stress-relief anneal, these alloys were alternately cross rolled and rolled lengthwise to 0.030 -in. strip, the total reduction being about 80 per cent. Considerable difficulty was experienced in obtaining the desired microstructure in this series of alloys, so the procedure was changed slightly for the fourth and final series of alloys.

The machined arc-cast buttons of the fourth series were rolled lengthwise and crosswise alternately, using equal reductions in both directions, down to a thickness of from 0.143 to 0.154 in. This represented a total reduction of 33 to 41 per cent. Alloy $85 \mathrm{~A}$ was not rolled, since it was already less than $0.150 \mathrm{in}$. thick. All of the alloys of this series were given a stress-relief anneal and then alternately cross rolled and rolled lengthwise to 0.030 -in. strip, a total reduction of 80 per cent. Alloys 85,87 to 100 , 102 , and 103 were rolled with equal reductions in both directions. The remaining alloys of this series were not rolled with equal reductions per direction. 
The rolling behavior of the alloys was observed and is discussed later. After evaluation at Battelle, cold-rolled specimens were sent to LASL for corrosion testing.

\section{Vacuum Annealing}

Vacuum annealing of the tantalum and tantalum-base alloys was necessary in order to prevent contamination from the environment. For example, tantalum absorbs hydrogen, nitrogen, and oxygen from the air at high rates, especially in the annealingtemperature range of $2600 \mathrm{~F}$. (5) The objectives of the annealing treatments were (1) to relieve stresses at an intermediate stage of processing, (2) to investigate the effects of a high-temperature homogenizing treatment at an intermediate stage of processing and (3) to obtain recrystallized fine-grained materials for plutonium-alloy-fuel cor rosion testing.

Prior to annealing, the materials were cleaned thoroughly, as indicated previously, and then handled with clean tongs to prevent contaminating with grease, which would be absorbed during heating. Three types of vacuum furnaces were used during the course of the program: a tantalum-element resistance furnace, a tungsten-element resistance furnace, and a high-frequency induction furnace having a clear fused-quartz work tube. The furnaces were cleaned thoroughly prior to each annealing run. The lowest possible furnace pressure was obtained and the leak rate was checked before heating the specimens. The leak rate was limited to a maximum of $0.2 \mu\left(2 \times 10^{-4} \mathrm{~mm}\right.$ of mercury $)$ per min. The materials were annealed at the selected temperature for specified periods of time. Temperature of the specimens was measured by means of an optical pyrometer. Corrections were made for the emissivity of tantalum(6) and for the sight glass.

Intermediate Annealing. As mentioned earlier, the objective of this annealing treatment was to relieve stresses introduced from the cold-pressing and cold-rolling operations, and to investigate the effects of a high-temperature homogenizing treatment. Table 7 summarizes the intermediate annealing treatments performed on the various series of alloys.

Final Annealing. In order to provide recrystallized, fine-grained materials for plutonium-fuel corrosion tests LASL and evaluational tests at Battelle, it was necessary to vacuum anneal specimens of the cold-rolled 0.030-in. strip material. Studies to determine optimum annealing temperatures were conducted on the first and fourth series of alloys. On the other hand, the actual corrosion-test specimens of the second and third series were annealed at various temperatures until the desired structures were obtained. Although an annealing study was conducted on the fourth alloy series, only the corrosion-test specimens of Alloys 95 to 100 were annealed at Battelle because of the termination of the program. Therefore, the remainder of these materials were sent to LASI for final annealing.

A complete breakdown of the final annealing temperatures and times is given in Table 14. Pressures ranged from $3.5 \times 10^{-6}$ to $7 \times 10^{-5} \mathrm{~mm}$ of mercury and leak rates were in the order of from 0.003 to $0.04 \mu$ per min. The results of annealing studies are presented and discussed later. Annealed materials were evaluated at Battelle by means of (1) metallographic examination, (2) hardness measurements, (3) chemical analyses, and (4) tensile tests. Then, specimens were forwarded to LASL for corrosion testing in plutonium-alloy fuel mixtures. 
TABLE 7. SUMMARY OF INTERMEDIATE VACUUM-ANNEALING TREATMENTS PERFORMED ON THE VARIOUS SERIES OF ALLOYS

\begin{tabular}{|c|c|c|c|c|c|}
\hline $\begin{array}{l}\text { Alloy } \\
\text { Series }\end{array}$ & $\begin{array}{c}\text { Alloy } \\
\text { Thickness, } \\
\text { in. }\end{array}$ & $\begin{array}{c}\text { Temperature, } \\
\text { F }\end{array}$ & $\begin{array}{c}\text { Time, } \\
\mathrm{hr}\end{array}$ & $\begin{array}{l}\text { Starting Pressure, } \\
\text { mm of mercury }\end{array}$ & $\begin{array}{l}\text { Leak Rate, } \\
\mu \text { per min }\end{array}$ \\
\hline \multicolumn{6}{|c|}{ Stress-Relief Anneal } \\
\hline $1^{(a)}$ & -. & -- & $\ldots$ & -- & -- \\
\hline 2 & $0.163-0.193$ & 2600 & 2 & $1.5-4.5 \times 10^{-6}$ & $0.02-0.045$ \\
\hline 3 & $0.142-0.148$ & 2600 & 1 & $\begin{array}{c}7.5 \times 10^{-6} \\
2 \times 10^{-5}\end{array}$ & $0.035-0.12$ \\
\hline $4^{(b)}$ & $0.143-0.154$ & 2600 & 1 & $3.5-5 \times 10^{-5}$ & 0.02 \\
\hline \multicolumn{6}{|c|}{ High-Temperature Homogenizing } \\
\hline $2^{(c)}$ & $0.165-0.175$ & 4000 & 2 & $6 \times 10^{-6}$ & 0.02 \\
\hline \multicolumn{6}{|c|}{$\begin{array}{l}\text { (a) The alloys of this series were not intermediate annealed because they were processed directly to } \\
0.030 \text {-in. strip. }\end{array}$} \\
\hline \multicolumn{6}{|c|}{$\begin{array}{l}\text { (b) The pressure and leak-rate data apply only to Alloys } 85,87 \text { to } 100,102 \text {, and } 103 \text {. The remaining } \\
\text { alloys of this series were annealed at LASL and the pressure and leak-rate data are not included here. } \\
\text { (c) The high-temperature homogenizing treatment was conducted only on portions of Alloys } 30,35 \text {, } \\
\text { and } 39 \text {. }\end{array}$} \\
\hline
\end{tabular}

\section{EVALUATIONAL PROCEDURES}

\section{Surface Tests for Iron}

Experience at Battelle and at LASL has shown that tantalum becomes contaminated superficially during fabrication, even though extreme care is taken to avoid it. The contaminant is principally iron. The special cleaning technique described previously was used to eliminate these surface-imbedded impurities. In order to determine whether the surface iron picked up during fabrication of the alloys was completely removed by the cleaning operation, it was necessary to employ some type of inspection test.

The first inspection test used was an X-ray fluorescence test. In this test the iron $\mathrm{K}$-alpha intensity was measured on both sides of a 0.030 -in. -thick specimen in two different areas. However, the results of these tests were rather questionable, because the internal iron count on the specimen was the same as that on the surface. It was felt that a simpler and faster qualitative test was needed to indicate the presence of surface iron contamination.

Therefore, a search was made for another test and it was learned that a potassium ferrocyanide test had been used in another program to detect the presence of iron on the surface of tantalum. (4) The procedure for this test was as follows:

(1) A dilute solution of potassium ferrocyanide was acidified with $\mathrm{HCl}$. 
(2) The tantalum or tantalum-alloy specimen was made the anode in the solution.

(3) A carbon rod was made the cathode in the solution.

(4) A potential of $6 \mathrm{v}$ was applied to the circuit.

The presence of iron on the surface of a specimen was indicated by bright blue spots or streaks at the iron-containing areas. This test was considered satisfactory and was used on the last three series of alloys. If iron was detected, the specimens were pickled in aqua regia until free of the iron. Thus, all specimens sent to LASL for corrosion testing were free of surface iron contamination, based on this ferrocyanide test.

\section{Chemical Analyses}

Chemical analyses were performed on the materials to determine the recovery of the alloying additions and to determine the impurity levels. The analyses indicated the purity of the melting stock, which was given earlier, and the effectiveness of the arcmelting and the vacuum-annealing operations.

Chemical samples generally consisted of small sheared pieces of the material to be analyzed. These samples were usually cleaned by degreasing with $c p$ acetone, washing in a boiling Alconox solution for $20 \mathrm{~min}$, rinsing with water, alcohol and then $\mathrm{cp}$ acetone, and dried thoroughly by heating to vaporize the acetone.

Carbon, nitrogen, and a few of the alloying additions were determined by wetanalysis techniques. Oxygen and hydrogen contents were determined by vacuum-fusion analysis. Spectrographic techniques were used to determine the trace elements and most of the alloying additions. Special techniques were developed to improve the results of the vacuum-fusion and spectrographic analyses.

\section{Metallography}

Cross sections of the tantalum and tantalum-base alloys were generally mounted in bakelite for microstructural examination and hardness determinations. Then the sections were wet ground successively with 240-, 400-, and 600-grit silicon carbide grinding papers. Final polishing was done on a high-speed (1750 rpm) polishing wheel covered with a Buehler Miracloth, using a slurry composed of $15 \mathrm{~g}$ of Linde $\mathrm{B}\left(\mathrm{Al}_{2} \mathrm{O}_{3}\right)$, $5 \mathrm{~cm}^{3}$ of 20 per cent chromic acid, and $35 \mathrm{~cm}^{3}$ of water. The specimens were then satisfactorily etched with one of the following etchants:

(1) 30 parts lactic acid - 10 parts $\mathrm{HNO}_{3}-10$ parts $\mathrm{HF}$.

(2) An electrolytic etchant consisting of 90 parts $\mathrm{H}_{2} \mathrm{SO}_{4}-10$ parts $\mathrm{HF}$.

The microstructural characteristics of the materials were observed by means of an optical microscope. In some alloys, a second phase was observed; however, no 
attempt was made to identify these phases. The large grain size of the materials in the as-cast condition was determined by (1) counting the total number of grains on the polished cross section of the specimen, (2) measuring the polished area with a polar planimeter, (3) calculating the number of grains per square millimeter, and (4) calculating the diameter of equivalent spherical grains.

The grain size of materials in the annealed condition was determined by direct comparison at 100 diameters with a standard ASTM grain-size chart. Then it was converted to average grain diameter in millimeters.

\section{$\underline{\text { Hardness Measurements }}$}

The hardness of the alloys was determined to gain information on alloying effects, work-hardening characteristics, and response to annealing. Hardness was used also to indicate the purity of the unalloyed tantalum control specimens. Mounted sections of the alloys used for microstructural examination were also used in hardness determinations. Five to ten Vickers hardness impressions, using a 5- or 10-kg load, were taken on a polished or etched surface. The average hardness was determined from these impressions. The Vickers hardness of tensile specimens was determined from impressions taken on the surface outside the reduced section. The surface condition was that present after cold rolling and/or annealing.

\section{$\underline{\text { Tensile Testing }}$}

The room-temperature tensile properties of the materials were determined to study the effects of alloying on strength and ductility, to investigate the influence of cold rolling and of annealing, and to provide data with which to evaluate the effect of irradiation. Tensile-specimen blanks were sheared from cold-rolled 0.030-in. strip and then ground to the following dimensions, using wate $r$ as a coolant to prevent overheating and concomitant contamination:
Length, in.
$4.50 \pm 1 / 64$
Width, in.
$11 / 32 \pm 1 / 64$
Gage Length, in.
$1.0 \pm 0.002$
Gage Width, in.
$0.250 \pm 0.002$
Radius at Gage Section, in.
1. 0

Most of the materials were tested in only the annealed condition. However, the tantalum and tantalum-tungsten alloys were also tested in the as-rolled condition. All of the specimens were tested with a Baldwin-Southwark universal testing machine using a strain rate of 0.005 in. per in. Templin grips were used to hold the specimens during testing. A clip-on extensometer was used with a recorder to obtain load-deformation curves. 


\section{Arc-Casting Behavior}

In general, the casting behavior of the unalloyed tantalum and tantalum-base alloys was good. Notable exceptions were the alloys containing charged additions of cerium, lanthanum, $3 \mathrm{w} / 0$ yttrium, 1.5 to $6 \mathrm{w} / 0$ thorium and $3 \mathrm{w} / 0$ silicon. The binary alloys containing the first three elements were difficult to form into a symmetrical button, due to the formation of "fingers". In addition, the cerium- and lanthanum-containing alloys had several voids. However, they were not remelted for fear of further vaporization of the alloy additions. The thorium-containing alloys contained a great deal of porosity which was not eliminated by remelting the buttons. The alloy containing $3 \mathrm{w} / 0$ silicon broke into several pieces during the cooling period after casting.

\section{Fabrication Behavior}

The relative fabrication behavior of the materials is indicated in Table 13 . In general, the tantalum and tantalum-base alloys could be fabricated at room temperature very easily into good quality 0.030 -in. strip. The poorest behavior of the fabricable alloys was exhibited by those containing charged additions of $6 \mathrm{w} / 0$ hafnium, $6 \mathrm{w} / 0$ rhenium, 0.5 to $6 \mathrm{w} / 0$ thorium, and $3 \mathrm{w} / 0$ zirconium. The poorest quality strip was that of the thorium-containing alloys.

As indicated in Table 13, the alloys with additions of from 0.5 to $1.0 \mathrm{w} / 0$ boron, 0.1 to $0.25 \mathrm{w} / 0$ carbon, and $1.0 \mathrm{w} / 0$ silicon were not fabricable. The extremely hard alloys with boron and silicon cracked into several pieces when the load was applied during the pressing operation. Although the alloys with carbon survived the pressing stage, they cracked catastrophically during the first cold-rolling step with a total reduction of about 32 per cent. Their failure was attributed to the presence of excessive amounts of a grain-boundary phase, presumably a carbide.

The work hardening of a few of the unalloyed tantalum buttons and tantalumtungsten alloys of the first series was studied. The results are shown in Table 8 and in Figure 2. These data show that, in general, the materials had a relatively low rate of work hardening during reductions of from 30 to 60 per cent. However, this rate increased fairly rapidly with reductions of 60 per cent and greater. It is interesting to note that the rates of work hardening were about the same for the unalloyed tantalum specimens. The rates of work hardening of the tungsten-containing alloys seemed, in some cases, to be slightly higher than those for the unalloyed tantalum.

\section{Annealing Studies}

As mentioned previously, studies were conducted on the first and fourth series of alloys to determine an optimum annealing temperature, i. e., a temperature at which a fine-grained structure of about minimum hardness could be obtained. In these studies, observations were made of the effect of annealing temperature on the hardness, and on the grain size, and also the effect of alloying on the recrystallization temperature. The 


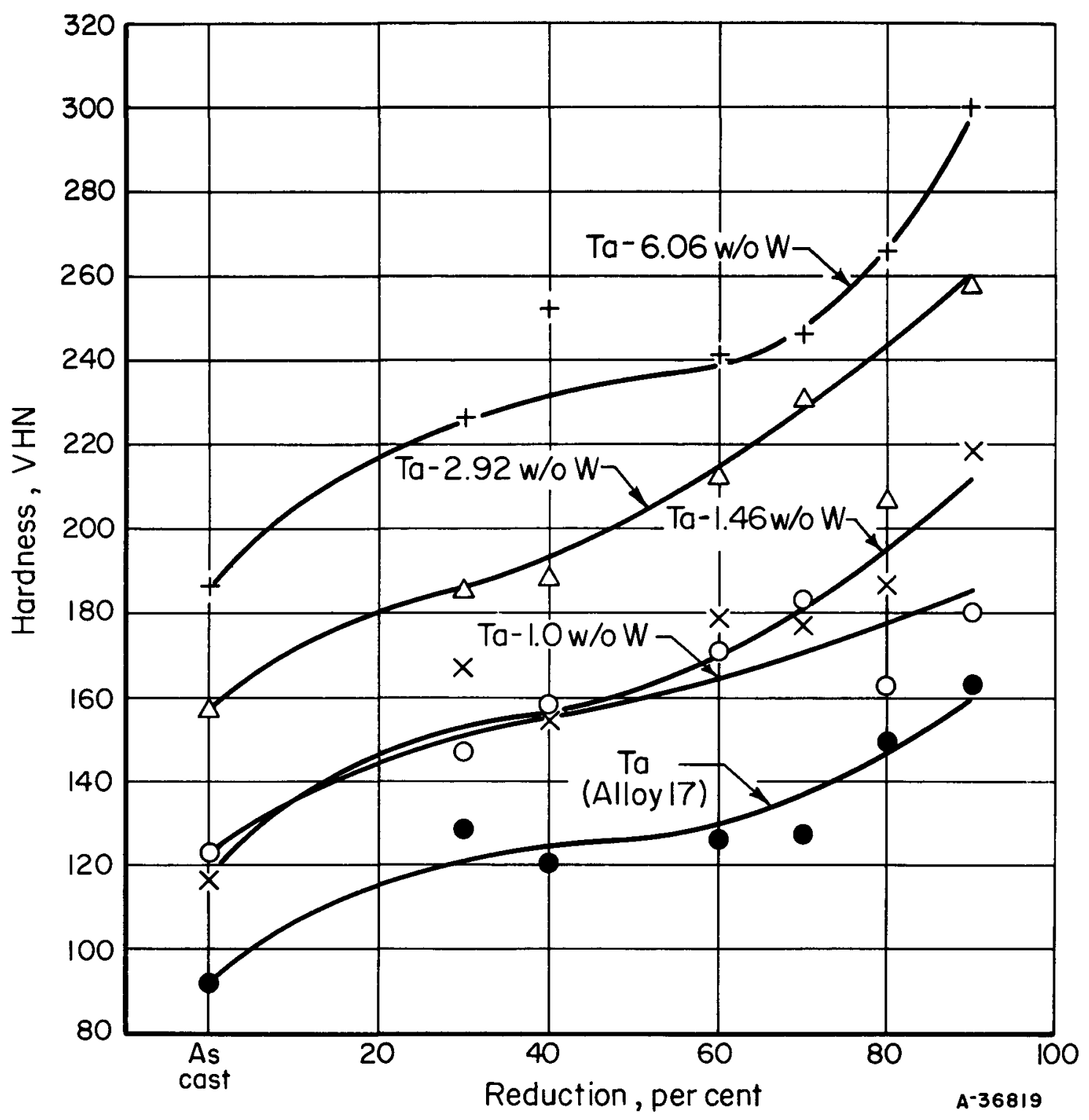

FIGURE 2. EFFECT OF COLD DEFORMATION ON THE HARDNESS OF TANTALUM AND TANTALUM-TUNGSTEN ALLOYS 
results of the annealing studies are shown in Tables 9 and 10 and Figures 3 and 4 . In Tables 9 and 10, the optimum annealing temperature is indicated for the materials and a time of $1 \mathrm{hr}$ at temperature is suggested. In general, an increase in the annealing temperature produced softer materials and larger grains.

TABLE 8. EFFECT OF COLD DEFORMATION ON THE HARDNESS OF TANTALUM AND TANTALUM-TUNGSTEN ALLOYS

\begin{tabular}{|c|c|c|c|c|c|c|c|c|}
\hline \multirow[b]{3}{*}{ Alloy } & \multirow{3}{*}{$\begin{array}{c}\text { Composition } \\
\text { (Balance Tantalum), } \\
\text { w/o }\end{array}$} & \multicolumn{7}{|c|}{ Hardness, VHN } \\
\hline & & \multirow[b]{2}{*}{ As Cast } & \multicolumn{6}{|c|}{ After Total Percentage Reduction Shown } \\
\hline & & & 30 & 40 & 60 & 70 & 80 & 90 \\
\hline 11 & $100 \mathrm{Ta}$ & 106 & 131 & 135 & 161 & 146 & 201 & 171 \\
\hline 17 & $100 \mathrm{Ta}$ & 92 & 129 & 121 & 127 & 128 & 150 & 163 \\
\hline 10 & $1.0 \mathrm{~W}(\mathrm{a})$ & 123 & 147 & 158 & 171 & 183 & 163 & 180 \\
\hline 18 & $1.46 \mathrm{~W}$ & 116 & 166 & 152 & 178 & 177 & 187 & 218 \\
\hline 4 & $2.92 \mathrm{~W}$ & 157 & 185 & 188 & 212 & 230 & 206 & 258 \\
\hline 9 & $6.06 \mathrm{~W}$ & 186 & 225 & 252 & 241 & 246 & 266 & 300 \\
\hline
\end{tabular}

(a) The tungsten in this alloy was a result of contamination from the electrode during arc melting.

TABLE 9. EFFECT OF ANNEALING TEMPERATURE ON THE HARDNESS AND GRAIN SIZE OF T ANT ALUM AND TANT ALUM-TUNGSTEN ALLOYS

\begin{tabular}{|c|c|c|c|c|c|c|c|c|c|c|}
\hline \multirow[b]{2}{*}{ Alloy } & \multirow{2}{*}{$\begin{array}{c}\text { Composition } \\
\text { (Balance Tantalum), } \\
\text { w/o }\end{array}$} & \multirow{2}{*}{$\begin{array}{c}\text { Hardness, } \\
\text { As Cold Rolled, } \\
\text { VHN }\end{array}$} & \multicolumn{7}{|c|}{$\begin{array}{l}\text { Hardness, VHN, and Average Grain Diameter, } \mathrm{mm} \text {, } \\
\text { After Annealing at Indicated Temperature }(\mathrm{a})\end{array}$} & \multirow{2}{*}{$\begin{array}{c}\text { Optimum } \\
\text { Annealing } \\
\text { Temperature } \\
\text { F } \\
\end{array}$} \\
\hline & & & $2010 \mathrm{~F}$ & $2205 \mathrm{~F}$ & $2415 \mathrm{~F}$ & $2610 \mathrm{~F}$ & $2815 \mathrm{~F}$ & $3000 \mathrm{~F}$ & $3270 \mathrm{~F}$ & \\
\hline 16 & $100 \mathrm{Ta}$ & 171 & $\begin{array}{l}121 \\
<0.02\end{array}$ & $\begin{array}{l}87 \\
0.05\end{array}$ & $\begin{array}{l}75 \\
0.07\end{array}$ & $\begin{array}{r}74 \\
0.07\end{array}$ & $\begin{aligned} 75 \\
0.10\end{aligned}$ & $\begin{array}{l}76 \\
0.28\end{array}$ & $\begin{array}{l}71 \\
>0.3\end{array}$ & 2600 \\
\hline 18 & $1.46 \mathrm{~W}$ & 227 & $\begin{array}{l}169 \\
<0.02\end{array}$ & $\begin{array}{l}114 \\
0.05\end{array}$ & $\begin{array}{l}92 \\
0.07\end{array}$ & $\begin{array}{l}94 \\
0.07\end{array}$ & $\begin{array}{l}94 \\
0.10\end{array}$ & $\begin{array}{l}97 \\
0.14\end{array}$ & $\begin{array}{l}85 \\
0.28\end{array}$ & 2600 \\
\hline 5 & $2.71 \mathrm{~W}$ & 243 & $\begin{array}{l}220 \\
<0.02\end{array}$ & $\begin{array}{l}176 \\
0.05\end{array}$ & $\begin{array}{l}119 \\
0.07\end{array}$ & $\begin{array}{r}116 \\
0.07\end{array}$ & $\begin{array}{r}114 \\
0.10\end{array}$ & $\begin{array}{r}117 \\
0.10\end{array}$ & $\begin{array}{r}109 \\
0.14\end{array}$ & 2600 \\
\hline 7 & $6.23 \mathrm{~W}$ & 299 & $\begin{array}{l}276 \\
<0.02\end{array}$ & $\begin{array}{r}268 \\
0.03\end{array}$ & $\begin{array}{r}180 \\
0.05\end{array}$ & $\begin{array}{r}177 \\
0.05\end{array}$ & $\begin{array}{r}177 \\
0.07\end{array}$ & $\begin{array}{r}172 \\
0.07\end{array}$ & $\begin{array}{l}164 \\
0.12\end{array}$ & 2600 \\
\hline
\end{tabular}

(a) Vacuum annealed $30 \mathrm{~min}$ for each alloy, the first line contains hardness data; the second line contains grain-size data. (b) Temperature required to produce a fine-grained structure of low hardness. Annealing for $1 \mathrm{hr}$ is recommended.

In the case of the unalloyed tantalum and the tantalum-tungsten alloys of the first series, the indications are that all of the materials were completely recrystallized after $30 \mathrm{~min}$ at $2400 \mathrm{~F}$. Then, between 2400 and $2800 \mathrm{~F}$, no significant change in the hardness or grain size was observed. However, above $2800 \mathrm{~F}$ the grain size increased greatly with only a slight decrease in hardness. The grain growth was more pronounced in the unalloyed tantalum. Increases in tungsten content had a progressively retarding effect on the grain growth. An optimum annealing temperature of $2600 \mathrm{~F}$ was selected for all the materials of the first series of alloys. 
TABLE 10. EFFECT OF ANNEALING TEMPERATURE ON THE HARDNESS OF BINARY TANTALUM-BASE ALLOYS

\begin{tabular}{|c|c|c|c|c|c|c|c|c|c|}
\hline \multirow[b]{3}{*}{ Alloy } & \multirow{3}{*}{$\begin{array}{c}\text { Composition } \\
\text { (Balance Tantalum), } \\
\text { w/o }\end{array}$} & \multicolumn{7}{|c|}{ Hardness, VHN } & \multirow{3}{*}{$\begin{array}{c}\text { Optimum } \\
\text { Annealing } \\
\text { Temperature(a) } \\
\text { F }\end{array}$} \\
\hline & & \multirow{2}{*}{$\begin{array}{l}\text { As Cold } \\
\text { Rolled }\end{array}$} & \multicolumn{6}{|c|}{ After Vacuum Annealing 30 Min at Indicated Temperature } & \\
\hline & & & $2200 \mathrm{~F}$ & $2400 \mathrm{~F}$ & $2600 \mathrm{~F}$ & $2800 \mathrm{~F}$ & $3000 \mathrm{~F}$ & $3200 \mathrm{~F}$ & \\
\hline \multicolumn{10}{|c|}{ Fourth Series, Group 1} \\
\hline 85 & $0.005 \mathrm{Y}$ & 147 & 98 & 83 & 80 & 79 & 89 & - & 2600 \\
\hline 89 & $0.4 \mathrm{Th}$ & 172 & 161 & 158 & 140 & 125 & 115 & -- & 3200 (b) \\
\hline 90 & $1.2 \mathrm{Th}$ & 171 & 160 & 156 & 145 & 133 & 121 & -- & $3200(b)$ \\
\hline 87 & $2.7 \mathrm{Th}$ & 203 & 169 & 167 & 146 & 135 & 119 & -- & $3200(\mathrm{~b})$ \\
\hline 88 & $5.6 \mathrm{Th}$ & 192 & 157 & 155 & 139 & 129 & 110 & -- & $320 \alpha(b)$ \\
\hline 91 & $<0.01 \mathrm{Fe}$ & 165 & 108 & 94 & 88 & 77 & 88 & -- & 2600 \\
\hline 92 & $0.015 \mathrm{Fe}$ & 198 & 133 & 116 & 117 & 111 & 119 & $-\infty$ & 2600 \\
\hline 95 & $0.5 \mathrm{Hf}$ & 192 & 161 & 124 & 118 & 105 & 107 & -- & 3000 \\
\hline 96 & 1. $5 \mathrm{Hf}$ & 214 & 169 & 136 & 123 & 124 & 124 & $=-$ & 3000 \\
\hline 97 & $3.0 \mathrm{Hf}$ & 251 & 212 & 188 & 144 & 144 & 144 & $-\infty$ & 3000 \\
\hline 98 & $0.43 \mathrm{Zr}$ & 197 & 195 & 134 & 119 & 114 & 117 & -- & 3000 \\
\hline 99 & $1.3 \mathrm{Zr}$ & 257 & 192 & 140 & 139 & 135 & 135 & -- & 3000 \\
\hline 100 & $2.9 \mathrm{Zr}$ & 293 & 188 & 174 & 182 & 190 & 193 & -- & 3000 \\
\hline 102 & $100 \mathrm{Ta}$ (control) & 165 & 87 & 81 & 75 & 73 & 76 & -- & 2600 \\
\hline 103 & $100 \mathrm{Ta}$ (control) & 190 & 115 & 93 & 88 & 87 & 113 & -- & 2600 \\
\hline \multicolumn{10}{|c|}{ Fourth Series, Group 2} \\
\hline 71 & $<0.001 \mathrm{Al}$ & 177 & $-\infty$ & 122 & 95 & 92 & 92 & 95 & 2800 \\
\hline 72 & $<0.001 \mathrm{Al}$ & 171 & $-\infty$ & 127 & 105 & 102 & 100 & 108 & 2800 \\
\hline 76 & $0.01 \mathrm{Be}$ & 208 & -- & 154 & 127 & 118 & 109 & 109 & 3200 \\
\hline 78 & $<0.10 \mathrm{Ce}$ & 139 & $-\infty$ & 115 & 100 & 96 & 100 & 109 & 3200 \\
\hline 80 & $<0.03 \mathrm{La}$ & 162 & $=-$ & 132 & 98 & 107 & 105 & 103 & 3000 \\
\hline 82 & $<0.10 \mathrm{Sc}$ & 179 & -- & 160 & 130 & 122 & 118 & 129 & 3000 \\
\hline 84 & $1.2 \mathrm{U}$ & 186 & -- & 132 & 118 & 111 & 112 & 115 & 2800 \\
\hline 86 & $0.01 \mathrm{Ti}$ & 168 & -- & 104 & 105 & 107 & 103 & 106 & 3200 \\
\hline 101 & $0.34 \mathrm{Ti}$ & 187 & -- & 140 & 118 & 120 & 125 & 131 & 2800 \\
\hline 109 & $0.001 \mathrm{Y}$ & 161 & $-m$ & 151 & 157 & 146 & 117 & 139 & 2800 \\
\hline 110 & $<0.001 \mathrm{Y}$ & 181 & -- & 140 & 165 & 173 & 179 & 173 & 2800 \\
\hline 104 & $100 \mathrm{Ta}$ (control) & 193 & $-=$ & 126 & 118 & 114 & 117 & 114 & 3200 \\
\hline 105 & $100 \mathrm{Ta}$ (control) & 120 & -- & 83 & 95 & 91 & 89 & 95 & 2600 \\
\hline
\end{tabular}

(a) Temperature required to produce a five-grained structure. Annealing for $1 \mathrm{hr}$ is recommended.

(b) Estimated because recrystallization was not complete at the highest temperature used in the study. 


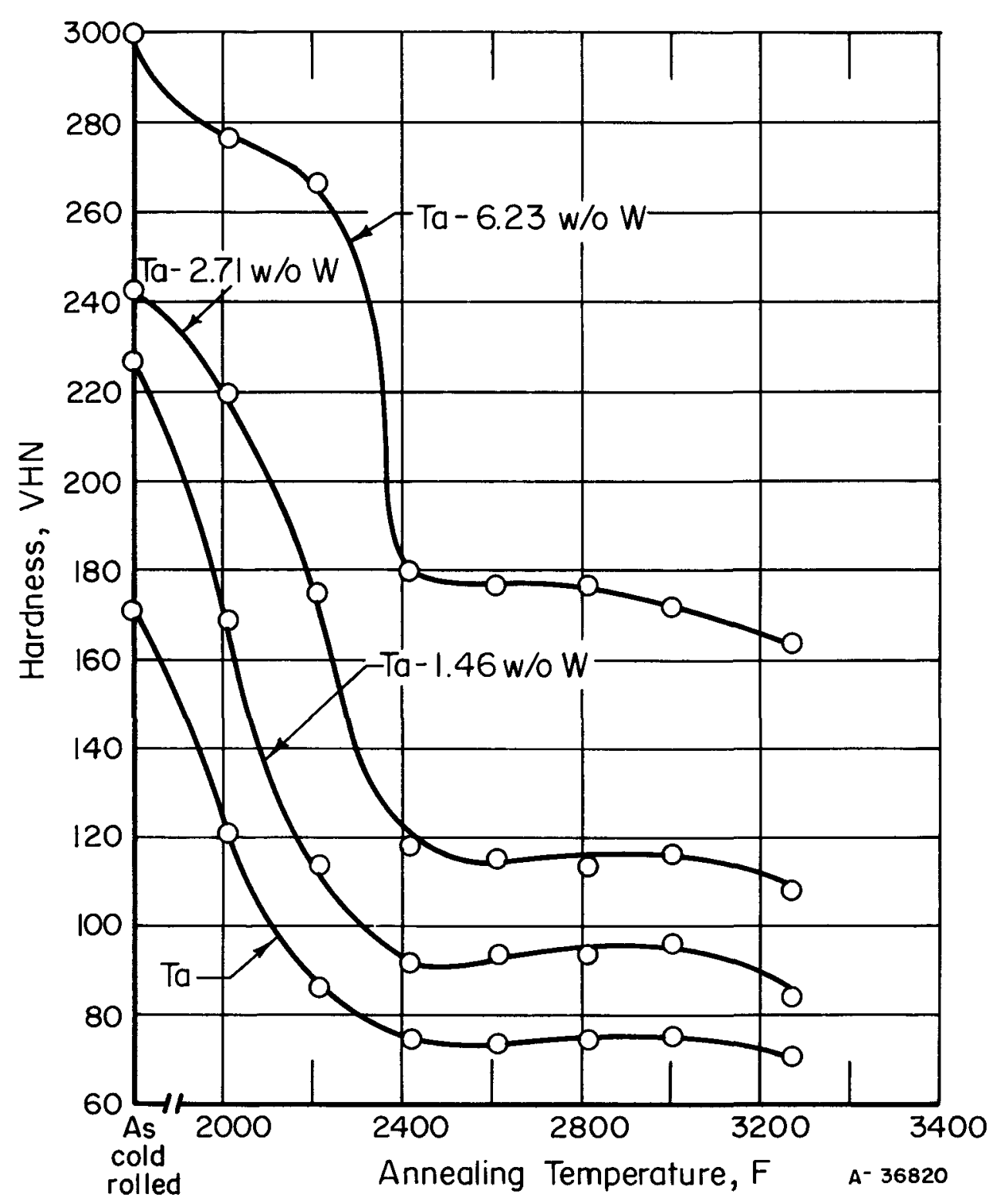

FIGURE 3. EFFECT OF ANNEALING TEMPERATURE ON THE HARDNESS OF TANTALUM AND TANTALUM-TUNGSTEN ALLOYS

Specimens cold rolled ( 90 per cent reduction) prior to annealing in vacuo for $30 \mathrm{~min}$. 


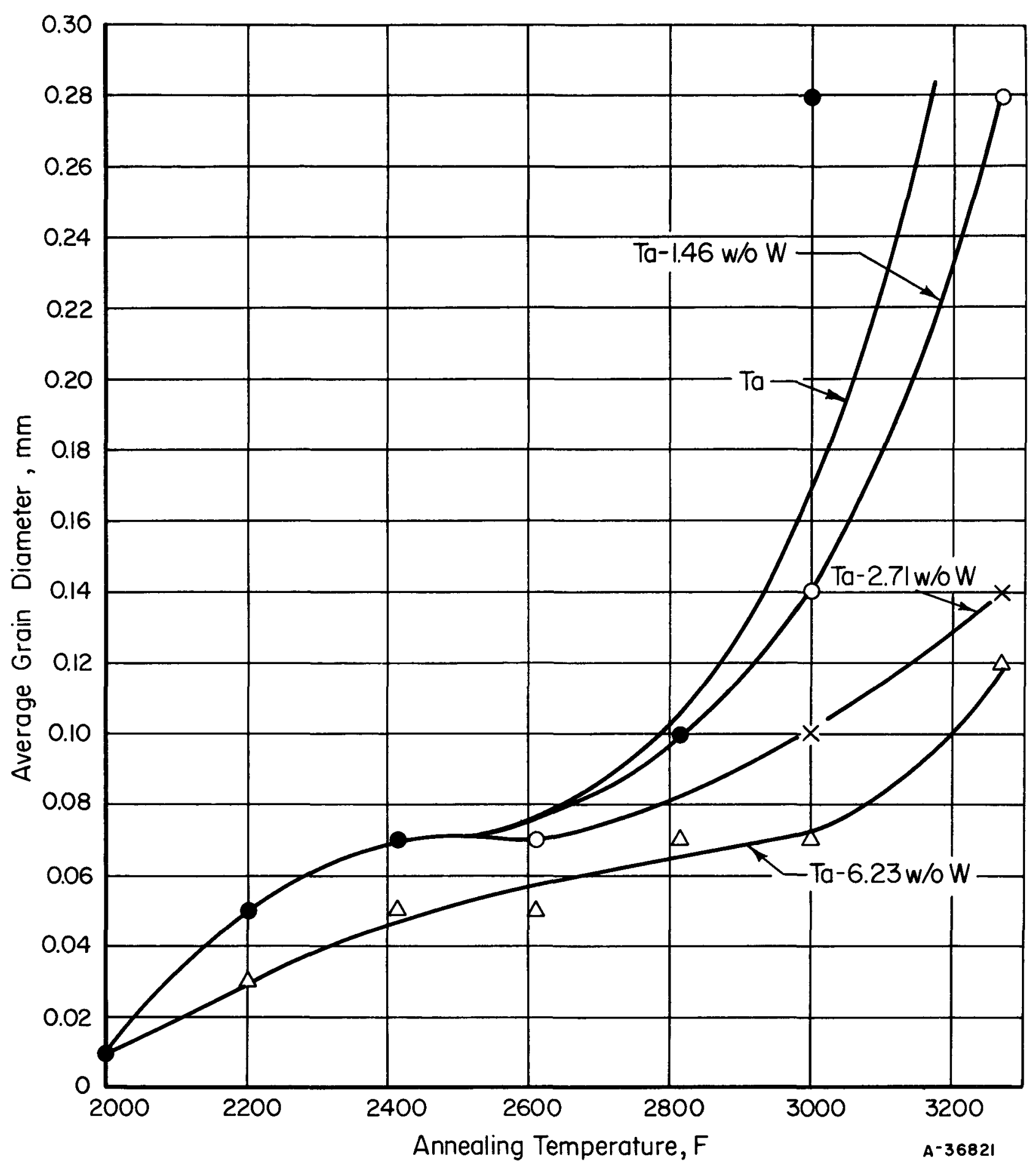

FIGURE 4. EFFECT OF ANNEALING TEMPERATURE ON THE GRAIN SIZE OF TANTALUM AND TANTALUM-TUNGSTEN ALLOYS

Specimens cold rolled ( 90 per cent reduction) prior to annealing in vacuo for $30 \mathrm{~min}$. 
Three of the unalloyed tantalum control specimens of the fourth series were also satisfactorily recrystallized at $2600 \mathrm{~F}$. However, one of the tantalum specimens (Alloy 104) was not completely recrystallized until treated at $3200 \mathrm{~F}$. The cause of its resistance to recrystallization was not determined. The variations in the hardness of the tantalum specimens was probably due to differences in impurity levels. However, chemical analyses were not performed to substantiate this.

It was difficult to select an optimum annealing temperature for two of the yttriumcontaining alloys (109 and 110) and those containing scandium and titanium, because of elongated grain structures and/or excessive banding (inhomogeneity).

The data in Table 10 indicate that optimum annealing temperature was increased significantly in alloys containing additions of beryllium, cerium, hafnium, lanthanum, thorium, and zirconium. For the tantalum-hafnium alloys, there was no significant change in hardness between 2600 and $3000 \mathrm{~F}$. The alloys containing thorium, as indicated in Table 10, were not completely recrystallized at $3000 \mathrm{~F}$. For these alloys, the optimum temperature was estimated as $3200 \mathrm{~F}$, because the hardness was still decreasing at $3000 \mathrm{~F}$. In the case of the tantalum-zirconium alloys, the data indicate that there was no significant change in hardness for the $0.43 \mathrm{w} / 0$ zirconium alloy between 2600 and $3000 \mathrm{~F}$ and for the $1.3 \mathrm{w} / 0$ zirconium alloy between 2400 and $3000 \mathrm{~F}$. The hardness of the $2.9 \mathrm{w} / \mathrm{o}$ zirconium alloy increased from a minimum of 174 VHN to a maximum of $193 \mathrm{VHN}$ at $3000 \mathrm{~F}$. The cause of this is not known, but it may have been due to the gettering action of the alloy during annealing.

\section{Chemical Analyses}

Because purity was considered as being extremely important in reference to the corrosion behavior of tantalum and its alloys in the plutonium fuels, most of the alloys were subjected to complete analyses in one or more of the following conditions: as cast, as rolled, and as annealed. Table 11 contains the results of the analyses performed on the materials.

In general, recovery of the following additions to tantalum was good: carbon, hafnium, rhenium, thorium, $0.025 \mathrm{w} / \mathrm{o}$ titanium, tungsten, uranium, and zirconium. However, the data show that the recovery of titanium in alloys containing charged additions of from 0.05 to $6 \mathrm{w} / \mathrm{o}$ was very poor. Also, practically all of the additions of aluminum, beryllium, cerium, iron, lanthanum, scandium, and yttrium were lost during arc melting. Several attempts were made to recover yttrium by using special melting practices, but without success.

In general, as indicated by the analytical data, the arc-melting procedures were effective in maintaining purity of the melting stock. However, some difficulty was experienced with tungsten contamination from the tungsten electrode. This is shown in the results for the unalloyed tantalum alloy, 10, the hafnium-containing alloys (46 through 50 , and 56) and the zirconium-containing alloys (53 and 54). LASL was especially interested in hafnium and zirconium and wanted to evaluate the effect of each, per se, on the corrosion resistance of tantalum. It was for this reason that another group of tantalum-hafnium and tantalum-zirconium alloys (95 through 100) was prepared later. The difficulty with tungsten contamination in the alloys was eliminated by conditioning the electrode with yttrium. A discussion of the use of yttrium to prevent tip loss was presented in a previous section concerned with arc melting. 
TABLE 11. CHEMICAL ANALYSES OF ARC-MELTED HIGH-PURITY TANTALUM AND TANTALUM-BASE ALLOYS

Composition

(Balance Tantalum), w/o $\quad$ Analyses, ppm

\begin{tabular}{llllllllllllllllllllllll} 
Alloy & Element & Charged & Actual & $\mathrm{C}$ & $\mathrm{H}$ & $\mathrm{N}$ & $\mathrm{O}$ & $\mathrm{Fe}$ & $\mathrm{Si}$ & $\mathrm{Cu}$ & $\mathrm{W}$ & $\mathrm{Nb}$ & $\mathrm{Zr}$ & $\mathrm{Al}$ & $\mathrm{Mo}$ & $\mathrm{Ni}$ & $\mathrm{Cr}$ \\
\hline
\end{tabular}

\section{First Series: As Cast}

\begin{tabular}{|c|c|c|c|c|c|c|c|c|c|c|c|c|c|c|c|c|}
\hline 11 & -- & $100 \mathrm{Ta}$ & -- & 30 & 5 & 30 & 23 & 10 & $<50$ & 50 & $<50$ & 100 & 10 & 20 & $<10$ & 20 \\
\hline 13 & -- & $100 \mathrm{Ta}$ & -- & 20 & 3 & 20 & 18 & 30 & 100 & 25 & $<50$ & 150 & 20 & 30 & $<10$ & 5 \\
\hline 16 & -- & $100 \mathrm{Ta}$ & -- & 30 & 3 & 30 & 18 & 30 & 100 & 15 & 100 & 150 & 20 & 30 & 50 & 5 \\
\hline 17 & -- & $100 \mathrm{Ta}$ & -- & 60 & 3 & 10 & 23 & 30 & 100 & 15 & 100 & 100 & 20 & 30 & $<10$ & 10 \\
\hline 10 & -- & $100 \mathrm{Ta}$ & -- & 80 & 6 & 60 & 21 & 1 & 10 & 6 & $1.0(a)$ & 100 & 300 & -- & -- & 1 \\
\hline 3 & $W$ & 1.5 & 1.71 & 80 & 6 & 40 & 20 & 8 & 30 & 10 & $-\infty$ & 300 & $<20$ & 20 & $<20$ & 8 \\
\hline 18 & W & 1.5 & 1.46 & 40 & 5 & 30 & 6 & -- & -- & -- & -- & -- & -- & -- & - & -- \\
\hline 19 & W & 1.5 & 1.45 & 40 & 4 & 10 & 11 & $<3$ & 30 & 30 & -- & 50 & $<10$ & $<10$ & $<20$ & $<3$ \\
\hline 4 & $W$ & 3.0 & 2.92 & 80 & 5 & 20 & 12 & 30 & 100 & 15 & -- & 100 & $<10$ & 30 & $<10$ & 3 \\
\hline 5 & W & 3.0 & 2.71 & 70 & 5 & 20 & 12 & 30 & 100 & 30 & - & 100 & $<10$ & 30 & $<10$ & $<3$ \\
\hline 6 & W & 3.0 & 2.94 & 50 & 3 & 30 & 17 & $<3$ & 20 & 10 & -- & 50 & $<10$ & $<10$ & $<20$ & $<3$ \\
\hline 7 & $W$ & 6.0 & 6.23 & 80 & 8 & 30 & 26 & $\infty$ & $-\infty$ & - & $=-$ & -- & -- & $\cdots$ & -- & -. \\
\hline 8 & W & 6.0 & 5.80 & 100 & 3 & 110 & 33 & 15 & 30 & 200 & -- & 150 & $<20$ & 20 & 50 & 25 \\
\hline 9 & W & 6.0 & 6.06 & 60 & 4 & 40 & 13 & $<3$ & 200 & 5 & -- & 50 & $<10$ & $<10$ & $<20$ & $<3$ \\
\hline
\end{tabular}

\section{First Series: As Rolled}

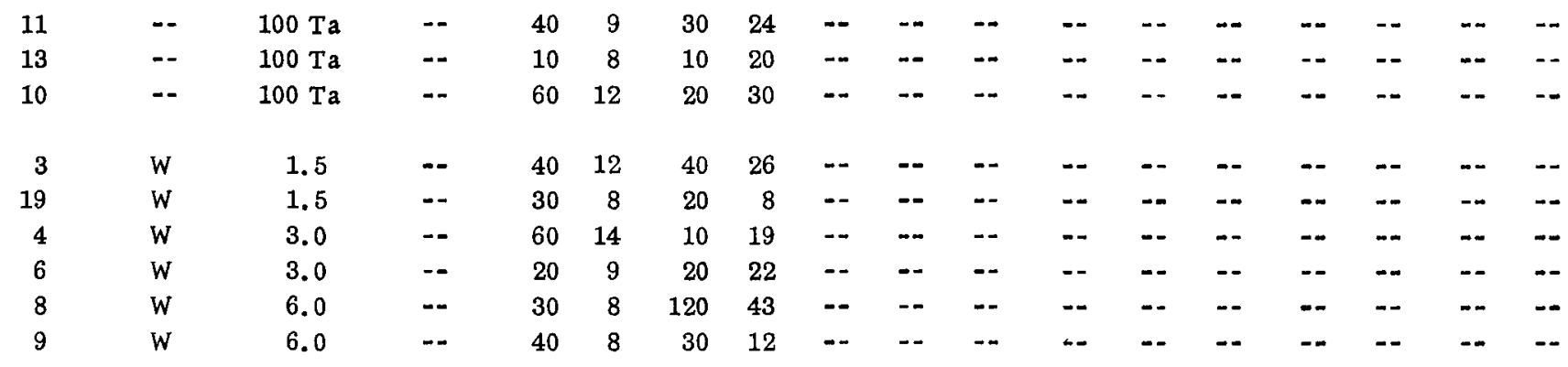

First Series: Vacuum Annealed(b)

\begin{tabular}{|c|c|c|c|c|c|c|c|c|c|c|c|c|c|c|c|c|}
\hline 11 & - & $100 \mathrm{Ta}$ & -- & 40 & 1.7 & 50 & 50 & - & - & $-\infty$ & $\cdots$ & $-\infty$ & $\ldots$ & $\cdots$ & -- & - \\
\hline 13 & - & $100 \mathrm{Ta}$ & -- & 30 & 0.6 & 30 & 17 & - & $\cdots$ & -- & -- & -- & - & -- & - & -- \\
\hline 16 & $=-$ & $100 \mathrm{Ta}$ & - & 20 & 0.4 & 50 & 45 & - & $-\infty$ & -- & - & - & - & -- & -- & -- \\
\hline 10 & -- & $100 \mathrm{Ta}$ & - & 50 & 2.0 & 70 & 46 & - & - & -- & -- & $-\infty$ & $-\infty$ & $-\infty$ & - & $-\infty$ \\
\hline 3 & W & 1.5 & $-\infty$ & 20 & 1.2 & 30 & 53 & $-\infty$ & - & $-\infty$ & -- & - & - & - & -- & - \\
\hline 19 & W & 1.5 & -- & 20 & 0.4 & 10 & 14 & -- & $-\infty$ & -- & $\infty$ & - & $\ldots$ & $-\infty$ & $\ldots$ & $-\infty$ \\
\hline 4 & W & 3.0 & - & 50 & 1.0 & 50 & 22 & -- & - & -- & - & - & $=-$ & $-\infty$ & $m$ & $\ldots$ \\
\hline 6 & $W$ & 3.0 & -- & 20 & 0.5 & 20 & 20 & - & - & -- & -- & - & -- & - & - & - \\
\hline 8 & W & 6.0 & $\infty$ & 10 & 0.6 & 140 & 93 & $\cdots$ & - & - & - & -- & -- & -- & -- & - \\
\hline 9 & W & 6.0 & -- & 30 & 0.1 & 30 & 19 & $\infty$ & - & $\infty$ & $-\infty$ & - & $-\infty$ & -. & $\rightarrow$ & - \\
\hline
\end{tabular}

\section{Second Series: As Rolled}

$\begin{array}{llllllllllllllllll}27 & -- & 100 & -- & 20 & 1.0 & 30 & 28 & <3 & <10 & 2<100 & 50 & <10 & <5 & <10 & 3 & 1 \\ & & & & & & & & & & & & & \\ 28 & \operatorname{Re} & 1.5 & 1.50 & 20 & 1.0 & 70 & 32 & <3 & 10 & 3<100 & 50 & <10 & <5 & <10 & <3 & 1 \\ 29 & \operatorname{Re} & 1.5 & 1.50 & 20 & 0.5 & 30 & 15 & 10 & 10 & 5<100 & 50 & <10 & <5 & <10 & <3 & 1\end{array}$


TABLE 11. (Continued)

\begin{tabular}{|c|c|c|c|c|c|c|c|c|c|c|c|c|c|c|c|c|c|}
\hline \multirow[b]{2}{*}{ Alloy } & \multicolumn{3}{|c|}{$\begin{array}{c}\text { Composition } \\
\text { (Balance Tantalum), w/o }\end{array}$} & \multicolumn{14}{|c|}{ Analyses, ppm } \\
\hline & Element & Charged & Actual & C & $\mathrm{H}$ & $\mathrm{N}$ & 0 & $\mathrm{Fe}$ & $\mathrm{Si}$ & $\mathrm{Cu}$ & $\mathrm{W}$ & $\mathrm{Nb}$ & $\mathrm{Zr}$ & Al & Mo & $\mathrm{Ni}$ & $\mathrm{Cr}$ \\
\hline 30 & $\operatorname{Re}$ & 3.0 & 2.85 & 40 & 1.5 & 50 & 24 & 3 & 30 & 10 & $<100$ & 50 & $<10$ & 5 & $<10$ & 5 & 1 \\
\hline 31 & $\operatorname{Re}$ & 3.0 & 2.75 & 60 & 0.5 & 50 & 17 & $<3$ & 30 & 5 & $<100$ & 50 & $<10$ & $<5$ & $<10$ & $<3$ & 1 \\
\hline 32 & $\operatorname{Re}$ & 6.0 & 6.0 & 50 & 2.5 & 10 & 25 & $<3$ & 30 & 5 & $<100$ & 50 & $<10$ & 5 & $<10$ & $<3$ & 2 \\
\hline 33 & $\operatorname{Re}$ & 6.0 & 6.2 & 20 & 0.5 & 20 & 14 & $<3$ & 30 & 10 & $<100$ & 50 & $<10$ & 5 & $<10$ & $<3$ & 2 \\
\hline 35 & C & 0.025 & 0.031 & -- & 1.0 & 20 & 16 & $<3$ & 10 & 10 & $<100$ & 50 & $<10$ & 5 & $<10$ & $<3$ & 2 \\
\hline 38 & $\mathrm{Y}$ & 0.025 & $<0.001$ & 10 & 1.5 & 20 & 22 & $<3$ & $<10$ & 20 & $<100$ & 50 & $<10$ & $<5$ & $<10$ & $<3$ & 2 \\
\hline 39 & $\mathrm{Y}$ & 0.10 & $<0.001$ & 10 & 1.0 & 10 & 16 & $<3$ & 20 & 5 & $<100$ & 50 & $<10$ & $<5$ & $<10$ & $<3$ & 2 \\
\hline 37 & $\mathbf{Y}$ & 0.25 & $<0.001$ & 20 & 3.0 & 70 & 18 & $<3$ & 10 & 5 & $<100$ & 50 & $<10$ & 10 & $<10$ & $<3$ & 2 \\
\hline \multicolumn{18}{|c|}{ Second Series: Vacuum Annealed(c) } \\
\hline 27 & -- & $\begin{array}{l}100 \mathrm{Ta} \\
\text { (control) }\end{array}$ & $-\infty$ & 10 & 0.5 & 30 & 37 & $<3$ & $<10$ & 3 & $<100$ & 50 & $<10$ & $<5$ & $<10$ & $<3$ & $<1$ \\
\hline 28 & $\operatorname{Re}$ & 1.5 & 1. 50 & 10 & 0.5 & 40 & 33 & 3 & 15 & 8 & $<100$ & 50 & $<10$ & $<5$ & $<10$ & $<3$ & $<1$ \\
\hline 31 & $\operatorname{Re}$ & 3.0 & 3.0 & 30 & 0.5 & 30 & 23 & $<3$ & 20 & 15 & $<100$ & 50 & $<10$ & $<5$ & $<10$ & $<3$ & $<1$ \\
\hline 33 & $\operatorname{Re}$ & 6.0 & 5.5 & 40 & 0.5 & 20 & 24 & $<3$ & 20 & 15 & $<100$ & 50 & $<10$ & $<5$ & $<10$ & $<3$ & $<1$ \\
\hline 35 & C & 0.025 & 0.028 & -- & 0.5 & 40 & 20 & $<3$ & $<10$ & 3 & $<100$ & 50 & $<10$ & $<5$ & $<10$ & $<3$ & $<1$ \\
\hline 38 & $\mathrm{Y}$ & 0.025 & $<0.001$ & 10 & 0.5 & 50 & 23 & 3 & 10 & 5 & $<100$ & 50 & $<10$ & $<5$ & $<10$ & $<3$ & $<1$ \\
\hline 39 & $Y$ & 0.10 & $<0.001$ & 60 & 0.5 & 30 & 9 & 3 & 10 & 30 & $<100$ & 50 & $<10$ & $<5$ & $<10$ & $<3$ & $<1$ \\
\hline 37 & $\mathrm{Y}$ & 0.25 & $<0.001$ & 10 & 0.5 & 80 & 25 & 3 & 10 & 3 & $<100$ & 50 & $<10$ & $<5$ & $<10$ & $<3$ & $<1$ \\
\hline \multicolumn{18}{|c|}{ Third Series: As Rolled } \\
\hline 44 & -- & $\begin{array}{l}100 \mathrm{Ta} \\
\text { (control) }\end{array}$ & - & 40 & 1.5 & 20 & 43.5 & $<3$ & $<1$ & 5 & 3000 & $<10$ & $<10$ & $<10$ & $<10$ & $<1$ & $<3$ \\
\hline 46 & Hf & 0.025 & 0.025 & 40 & 1.5 & 10 & 30 & $<3$ & $<1$ & 8 & 3000 & $<10$ & $<10$ & $<10$ & $<10$ & $<1$ & 20 \\
\hline 47 & $\mathrm{Hf}$ & 0.05 & 0.046 & 40 & 1.5 & $<10$ & 31 & $<3$ & $<1$ & 5 & 2000 & $<10$ & $<10$ & $<10$ & $<10$ & $<1$ & $<3$ \\
\hline 52 & $\mathrm{Hf}$ & 0.10 & 0.10 & 40 & 0.5 & 30 & 38 & $<3$ & $<1$ & 10 & 350 & $<10$ & $<10$ & $<10$ & $<10$ & $<1$ & $<3$ \\
\hline 49 & $\mathrm{Hf}$ & 1.5 & 1.3 & 150 & 0.3 & 100 & 28.5 & $<3$ & $<1$ & 15 & $1.1(\mathrm{a})$ & $<10$ & 110 & $<10$ & $<10$ & $<1$ & $<3$ \\
\hline 50 & $\mathrm{Hf}$ & 3.0 & 2.7 & 150 & 0.6 & 20 & 20.5 & $<3$ & $<1$ & 10 & 6600 & $<10$ & 220 & $<10$ & $<10$ & $<1$ & $<3$ \\
\hline 56 & Hf & 6.0 & 5.55 & 20 & 1.2 & 20 & 12 & $<3$ & $<1$ & 10 & 250 & $<10$ & 380 & $<10$ & $<10$ & $<1$ & $<3$ \\
\hline 53 & $\mathrm{Zr}$ & 0.025 & 0.021 & 60 & 0.6 & 30 & 32.5 & $<3$ & $<1$ & 5 & 500 & $<10$ & - & $<10$ & $<10$ & $<1$ & $<3$ \\
\hline 54 & $\mathrm{Zr}$ & 0.05 & 0.033 & 40 & 0.5 & $<10$ & 23.5 & $<3$ & $<1$ & 8 & 500 & $<10$ & -- & $<10$ & $<10$ & $<1$ & $<3$ \\
\hline 55 & $\mathrm{Zr}$ & 0.10 & 0.071 & 30 & 0.9 & 10 & 20.5 & $<3$ & $<1$ & 10 & $<30$ & $<10$ & -- & $<10$ & $<10$ & $<1$ & $<3$ \\
\hline 51 & $\mathbf{Z r}$ & 1.5 & 1.24 & 40 & 0.3 & 220 & 41.5 & $<3$ & $<1$ & 5 & 100 & $<10$ & -. & $<10$ & $<10$ & $<1$ & $<3$ \\
\hline 57 & $\mathrm{Zr}_{\mathrm{r}}$ & 3.0 & 2.65 & 20 & 0.7 & 10 & 9.5 & $<3$ & $<1$ & 10 & $<30$ & $<10$ & -. & $<10$ & $<10$ & $<1$ & $<3$ \\
\hline 59 & $T \mathbf{i}$ & 0.025 & 0.015 & 10 & 0.3 & 40 & 19.5 & $<3$ & $<1$ & 5 & $<30$ & $<10$ & $<10$ & $<10$ & $<10$ & $<1$ & $<3$ \\
\hline 60 & $\mathrm{Ti}$ & 0.05 & 0.004 & 20 & 0.7 & 20 & 20 & $<3$ & $<1$ & 10 & 200 & $<10$ & $<10$ & $<10$ & $<10$ & $<1$ & $<3$ \\
\hline 61 & $\mathrm{Ti}$ & 0.10 & 0.030 & 10 & 0.6 & 50 & 17.5 & $<3$ & $<1$ & 5 & $<30$ & $<10$ & $<10$ & $<10$ & $<10$ & $<1$ & $<3$ \\
\hline 62 & Th & 0.025 & 0.018 & 40 & 0.4 & 40 & 27 & $<3$ & $<1$ & 5 & $<30$ & $<10$ & $<10$ & $<10$ & $<10$ & $<1$ & $<3$ \\
\hline 63 & Th & 0.05 & 0.034 & 20 & 0.3 & 60 & 20 & $<3$ & $<1$ & 5 & $<30$ & $<10$ & $<10$ & $<10$ & $<10$ & $<1$ & $<3$ \\
\hline 64 & Th & 0.10 & 0.061 & 20 & 0.5 & 20 & 12.5 & $<3$ & $<1$ & 8 & $<30$ & $<10$ & $<10$ & $<10$ & $<10$ & $<1$ & $<3$ \\
\hline
\end{tabular}


TABLE 11. (Continued)

Composition

(Balance Tantalum), w/o

\begin{tabular}{|c|c|c|c|c|c|c|c|c|c|c|c|c|c|c|c|c|c|}
\hline \multirow[b]{2}{*}{ Alloy } & & \\
\hline & Element & Charged & Actual & $C$ & $\mathrm{H}$ & $\mathrm{N}$ & 0 & $\mathrm{Fe}$ & Si & $\mathrm{Cu}$ & $\mathrm{W}$ & $\mathrm{Nb}$ & $\mathrm{Zr}$ & $\mathrm{A} 1$ & Mo & $\mathrm{Ni}$ & $\mathrm{Cr}$ \\
\hline 65 & W & 3.0 & 2.5 & 20 & 0.6 & 30 & 22 & $<3$ & $<1$ & 4 & $-\infty$ & $<10$ & $<10$ & $<10$ & $<10$ & $<1$ & $<3$ \\
\hline 66 & $Y$ & 0.025 & $<0.0005$ & 20 & 0.1 & 20 & 19.5 & $<3$ & $<1$ & 2 & $<30$ & $<10$ & $<10$ & $<10$ & $<10$ & $<1$ & $<3$ \\
\hline 67 & $\mathrm{Y}$ & 0.05 & $<0.0005$ & 20 & 0.7 & 20 & 16.5 & $<3$ & $<1$ & 2 & $<30$ & $<10$ & $<10$ & $<10$ & $<10$ & $<1$ & $<3$ \\
\hline 68 & $Y$ & 0.10 & $<0.0005$ & 20 & 0.6 & 20 & 12 & $<3$ & $<1$ & 4 & $<30$ & $<10$ & $<10$ & $<10$ & $<10$ & $<1$ & $<3$ \\
\hline 69 & $Y$ & 0.20 & $<0.0005$ & 20 & 0.6 & 40 & 10 & $<3$ & $<1$ & 5 & $<30$ & $<10$ & $<10$ & $<10$ & $<10$ & $<1$ & $<3$ \\
\hline
\end{tabular}

Third Series: Vacuum Annealed(c)

\begin{tabular}{|c|c|c|c|c|c|c|c|c|c|c|c|c|c|c|c|c|c|}
\hline 44 & $-\infty$ & $\begin{array}{l}100 \mathrm{Ta} \\
\text { (control) }\end{array}$ & -- & 30 & 0.2 & 40 & 52 & -- & 2 & 10 & 2000 & -- & $<10$ & -- & -- & 2 & $<3$ \\
\hline 46 & Hf & 0.025 & 0.027 & 40 & 1.2 & 40 & 60 & $\cdots$ & -- & -- & 6400 & $-\infty$ & $<200$ & -- & -- & 2 & $<3$ \\
\hline 47 & $\mathrm{Hf}$ & 0.05 & 0.043 & 50 & 0.6 & 20 & 54 & -- & - & -- & 2800 & -- & $<200$ & -- & -- & -- & -- \\
\hline 52 & $\mathrm{Hf}$ & 0.10 & 0.096 & 50 & 0.2 & 60 & 36.5 & - & 2 & 80 & 300 & $-\infty$ & $<10$ & -- & $\cdots$ & 2 & $<3$ \\
\hline 49 & $\mathrm{Hf}$ & 1.5 & 1.20 & 160 & 0.2 & 110 & 21.5 & -- & 1 & 80 & $1.0^{(a)}$ & $\infty$ & 250 & -- & - & -- & $<3$ \\
\hline 50 & $\mathrm{Hf}$ & 3.0 & 2.70 & 170 & 0.3 & 30 & 8 & -- & $m$ & -- & 7200 & -- & 240 & - & -- & -- & -- \\
\hline 56 & Hf & 6.0 & 5.25 & 30 & 0.1 & 30 & 15 & - & $<1$ & 50 & 300 & - & 500 & -- & $-\infty$ & 4 & 3 \\
\hline 53 & $\mathrm{Zr}$ & 0.025 & 0.033 & 70 & 0.1 & 60 & 18.5 & - & $<1$ & 15 & 500 & -- & - & -- & -- & $<1$ & $<3$ \\
\hline 54 & $\mathrm{Zr}$ & 0.05 & 0.027 & 80 & 0.4 & 20 & 107 & -- & -- & -- & -- & -- & $-\infty$ & -- & -- & -- & -- \\
\hline 55 & $\mathrm{Zr}$ & 0.10 & 0.10 & 50 & 0.1 & 40 & 23 & -- & 1 & 10 & $<30$ & $\cdots$ & - & -- & -- & 4 & $<3$ \\
\hline 51 & $\mathrm{Zr}$ & 1.5 & 1.26 & 50 & 0.4 & 220 & 54 & -- & -- & - & -- & -- & - & -- & - & -- & -- \\
\hline 57 & $\mathrm{Zr}$ & 3.0 & 2.75 & 40 & 0.3 & 50 & 21 & -- & 2 & 80 & 200 & -- & -- & -- & -- & $<1$ & $<3$ \\
\hline 59 & $T i$ & 0.025 & 0.024 & 10 & 0.1 & 40 & 22 & $m$ & -- & 15 & 100 & $\cdots$ & $<10$ & -- & - & $-\infty$ & -. \\
\hline 60 & $\mathrm{Ti}$ & 0.05 & 0.027 & 10 & 0.1 & 10 & 23.5 & - & -- & 20 & 200 & -- & $<10$ & -- & - & -- & $\cdots$ \\
\hline 61 & $\mathrm{Ti}$ & 0.10 & 0.030 & 20 & 0.2 & 40 & 20 & -- & -- & 10 & 100 & -- & $<10$ & $=$ & -- & -- & -- \\
\hline 62 & Th & 0.025 & 0.019 & 80 & 0.2 & 50 & 39 & - & - & $-\infty$ & $-\infty$ & -- & -- & -- & -- & $\rightarrow$ & - \\
\hline 63 & Th & 0.05 & 0.031 & 40 & 1.2 & 70 & 32 & - & -- & - & $-\infty$ & - & - & -- & - & -- & -- \\
\hline 64 & Th & 0.10 & 0.066 & 110 & 0.2 & 50 & 106 & - & -- & -- & -- & -- & -- & -- & -- & -- & -- \\
\hline 65 & W & 3.0 & 2.90 & 30 & 0.2 & 20 & 20 &.- & $-\infty$ & 20 & $\cdots$ & $\cdots$ & $<10$ & -- & -- & $-\infty$ &.- \\
\hline 66 & $\mathrm{Y}$ & 0.025 & $<0.001$ & 40 & 0.4 & 20 & 59 & -- & -- & $-\infty$ & $<50$ & -- & $<10$ & -- & - & -- & -- \\
\hline 67 & $\mathbf{Y}$ & 0.05 & $<0.001$ & 40 & 1.5 & 20 & 66 & - & $\infty$ & -- & $<50$ & $-\infty$ & $<10$ & -- & - & - & - \\
\hline 68 & $\mathrm{Y}$ & 0.10 & $<0.001$ & 50 & 0.2 & 30 & 90 & -- & -- & $-\infty$ & $<50$ & -- & $<10$ & -- & $-\infty$ & $-\infty$ & - \\
\hline 69 & $\mathrm{Y}$ & 0.20 & $<0.001$ & 60 & 1.0 & 40 & 63 & - & $\infty$ & -- & $<50$ & -- & $<10$ & -. & - & -- & -- \\
\hline
\end{tabular}

Fourth Series (Group 1): As Rolled

\begin{tabular}{|c|c|c|c|c|c|c|c|c|c|c|c|c|c|c|c|c|}
\hline 102 & -- & $\begin{array}{l}100 \mathrm{Ta} \\
\text { (control) }\end{array}$ & -- & -- & -- & -- & -- & $<10$ & $<10$ & $<10$ & $<300$ & $<50$ & $<10$ & -- & $-\infty$ & $--<10$ \\
\hline 103 & -- & $\begin{array}{l}100 \mathrm{Ta} \\
\text { (control) }\end{array}$ & -- & -- & -- & -- & -- & $<10$ & 10 & $<10$ & $<300$ & $<50$ & $<10$ & -- & $-\infty$ & $-\infty<10$ \\
\hline 85 & $Y$ & 3.0 & 0.005 & $\cdots$ & -- & $\cdots$ & -- & $<10$ & $<10$ & $<10$ & $<300$ & $<50$ & $<10$ & -- & -- & $--<10$ \\
\hline 89 & Th & 0.5 & 0.4 & -- & -- & -- & - & $<10$ & $<10$ & $<10$ & $<300$ & $<50$ & $<10$ & -- & -- & $--<10$ \\
\hline 90 & Th & 1.5 & 1.2 & $-\infty$ & -- & -- & -- & $<10$ & $<10$ & $<10$ & $<300$ & $<50$ & $<10$ & -- & -- & $\infty<10$ \\
\hline 87 & Th & 3.0 & 2.7 & $\cdots$ & -- & - & - & $<10$ & $<10$ & $<10$ & $<300$ & $<50$ & $<10$ & -- & -- & $--<10$ \\
\hline 88 & Th & 6.0 & 5.6 & - & - & - & $\ldots$ & $<10$ & $<10$ & $<10$ & $<300$ & $<50$ & $<10$ & 50 & -- & $-<<10$ \\
\hline
\end{tabular}


TABLE 11. (Continued)

\begin{tabular}{|c|c|c|c|c|c|c|c|c|c|c|c|c|c|c|c|c|c|}
\hline \multirow[b]{2}{*}{ Alloy } & \multicolumn{3}{|c|}{$\begin{array}{c}\text { Composition } \\
\text { (Balance Tantalum), w/o } \\
\end{array}$} & \multicolumn{14}{|c|}{ Analyses, ppm } \\
\hline & Element & Charged & Actual & $\bar{C}$ & $\overline{\mathrm{H}}$ & $\mathrm{N}$ & 0 & $\mathrm{Fe}$ & $\overline{\mathrm{Si}}$ & $\mathrm{Cu}$ & W & $\mathrm{Nb}$ & $\mathrm{Zr}$ & $\mathrm{Al}$ & Mo & $\mathrm{Ni}$ & $\overline{\mathrm{Cr}}$ \\
\hline 91 & $\mathrm{Fe}$ & 1.0 & $<0.01$ & -- & -- & -- & -- & -- & $<10$ & $<10$ & $<300$ & $<50$ & $<10$ & -- & -- & -- & $<10$ \\
\hline 92 & $\mathrm{Fe}$ & 3.0 & 0.015 & -- & - & -- & -- & - & $<10$ & $<10$ & $<300$ & $<50$ & $<10$ & -- & -- & -- & $<10$ \\
\hline 95 & $\mathrm{Hf}$ & 0.5 & 0.5 & -- & -- & -- & -- & $<10$ & $<10$ & $<10$ & $<300$ & $<50$ & $<10$ & -- & -- & -- & $<10$ \\
\hline 96 & $\mathrm{Hf}$ & 1.5 & 1.5 & -- & - & $-\infty$ & -- & $<10$ & $<10$ & $<10$ & $<300$ & $<50$ & $<10$ & -. & -- & -- & $<10$ \\
\hline 97 & $\mathrm{Hf}$ & 3.0 & 3.0 & -- & -- & -- &.- & $<10$ & $<10$ & $<10$ & $<300$ & $<50$ & $<10$ & - & -- & - & $<10$ \\
\hline 98 & $\mathrm{Zr}$ & 0.5 & 0.43 & -- & -- & -- & -- & $<10$ & $<10$ & $<10$ & $<300$ & $<50$ & $\ldots$ & -- & -- & -- & $<10$ \\
\hline 99 & $\mathrm{Zr}$ & 1.5 & 1.3 & -- & -- & $\cdots$ & -- & $<10$ & $<10$ & $<10$ & $<300$ & $<50$ & -- & -- & -- & -- & $<10$ \\
\hline 100 & $\mathrm{Zr}$ & 3.0 & 2.9 & -- & -- & - & -- & $<10$ & $<10$ & $<10$ & $<300$ & $<50$ & -- & -- & -- & -- & $<10$ \\
\hline \multicolumn{18}{|c|}{ Fourth Series (Group 2)(d): As Rolled } \\
\hline 104 & -- & $\begin{array}{l}100 \mathrm{Ta} \\
\text { (control) }\end{array}$ & - & - & -- & $\cdots$ & -- & $\cdots$ & -- & -- & -- & -- & -- & $\cdots$ & -- & - & $\cdots$ \\
\hline 105 & -- & $\begin{array}{l}100 \mathrm{Ta} \\
\text { (control) }\end{array}$ & - & -- & -- & -- & -- & $\cdots$ & -- & -- & -- & -- & -- & -- & -- & -- & $\cdots$ \\
\hline 71 & $\mathrm{Al}$ & 0.5 & $<0.001$ & $\cdots$ & -- & -- & -- & - & -- & -- & -- & - & $\ldots$ & $\cdots$ & - & -- & -- \\
\hline 72 & Al & 1.0 & $<0.001$ & -- & -- & -- & -- & $-\infty$ & -- & -- & - & $\ldots$ & -- & - & - & -- & $\sim$ \\
\hline 76 & $\mathrm{Be}$ & 2.0 & 0.01 & -- & -- & -- & -- & -- & -- & -- & -- & -- & -- & -- & -- & -- & -- \\
\hline 78 & $\mathrm{Ce}$ & 2.0 & $<0.10$ & -- & -- & - & -- & -- & - & - & - & $\cdots$ & -- & -- & -- & $\cdots$ & -- \\
\hline 80 & $\mathrm{La}$ & 2.0 & $<0.03$ & - & -- & -- & -- & -- & -- & -- & - & -- & -- & - & -- & -- & - \\
\hline 82 & $\mathrm{Sc}$ & 1.5 & $<0.10$ & -- & -- & -- & - & -- & -. & -- & $\ldots$ & -- & - & $\cdots$ & - & $-\cdots$ & 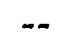 \\
\hline 84 & $\mathrm{U}$ & 2.0 & 1.20 & - & -- & - & - & -- & -- & $\cdots$ & -- & -- & -- & - & -- & -- & -- \\
\hline 86 & $\mathrm{Ti}$ & 2.0 & 0.01 & -- & -- & -- & -- & -- & -- & -- & -- & -. & -- & -- & -- & -. & -. \\
\hline 101 & $\mathrm{Ti}$ & 6.0 & 0.34 & -- & $\ldots$ & - & $\ldots$ & -- & -. & -- & - & -- & -- & -- & -- & -- & -- \\
\hline 109 & $Y$ & 3.0 & 0.001 & -- & -- & -- & -- & -- & -- & -- & - & -- & $-\infty$ & -. & -. & - & -- \\
\hline 110 & $\mathrm{Y}$ & 3.0 & $<0.001$ & $\cdots$ & -- & -- & $\cdots$ & -- & $\cdots$ & -- & -- & -. & - & -. & -- & -- & -- \\
\hline
\end{tabular}

(a) Value is in $w / o$.

(b) Annealed $2 \mathrm{hr}$ at $2600 \mathrm{~F}$.

(c) Refer to Table 13 for annealing conditions.

(d) Analyses for trace elements and interstitials were not performed on this group of alloys. 
The high carbon content in two of the hafnium alloys (49 and 50) was probably caused by overheating the Wilson vacuum seal on top of the arc-melting furnace. The cause of the unusually high nitrogen levels, 100 and $220 \mathrm{ppm}$, in Alloys 49 and 51 was not determined, but it was thought to have been due to a slight air leak during melting.

An interesting phenomenon is seen on comparing the oxygen contents of the coldrolled materials of the third series of alloys with the amount of alloying element present. Generally speaking, the oxygen content decreased significantly as the amount of the alloying element - hafnium, thorium, titanium, yttrium, zirconium - increased. This suggests that all of these elements were effective scavengers of oxygen in tantalum.

A comparison of the analytical data for the rolled and the annealed materials shows that vacuum annealing at 2600 to $2750 \mathrm{~F}$ resulted in a slight increase in nitrogen and oxygen levels and a decrease in hydrogen. Annealing at $2900 \mathrm{~F}$ caused a substantial increase in gaseous contamination. The increase in carbon levels in some of the annealed materials was believed to have been caused by the back flow of diffusion-pump oil.

\section{Microstructure}

All of the materials prepared in this program were examined metallog raphically to observe the characteristics of the alloys in reference to the type structure (single phase or two phase), homogeneity, and grain size.

Table 12 summarizes the microstructures observed for the unalloyed tantalum and all of the binary tantalum-base alloys. Figure 5 shows the microstructure of a typical unalloyed high-purity tantalum control specimen (Alloy 13) in the as-cast, as-rolled, and as-annealed conditions. The photomicrograph of the as-cast specimen is also representative of the single-phase tantalum-base alloys except for grain size, which varied considerably depending upon the alloy.

TABLE 12. SUMMARY OF MICROSTRUCTURES OBSERVED IN AS-CAST TANTALUM-BASE ALLOYS

\begin{tabular}{cc}
\hline \multicolumn{2}{c}{ Actual Composition (Balance Tantalum), w/o } \\
\hline Single-Phase Structures & Two-Phase Structures \\
\hline Unalloyed Tantalum & -- \\
$<0.001 \mathrm{Al}$ & -- \\
-- & $0.5-1.0 \mathrm{~B}^{(\mathrm{a})}$ \\
-- & $0.01 \mathrm{Be}$ \\
-- & $0.028-0.031 \mathrm{C}$ \\
-- & $0.10-0.25 \mathrm{C}(\mathrm{a})$ \\
$<0.10 \mathrm{Ce}$ & -- \\
$<0.01-0.015 \mathrm{Fe}$ & -- \\
$0.025-5.55 \mathrm{Hf}$ & -- \\
-- & $<0.03 \mathrm{La}$ \\
$1.5-6.2 \mathrm{Re}$ & -- \\
-- & $<0.10 \mathrm{Sc}$ \\
-- & $1.0-3.0 \mathrm{Si}(\mathrm{a})$ \\
$0.018-0.066 \mathrm{Th}$ & $0.4-5.6 \mathrm{Th}$ \\
$0.015-0.34 \mathrm{Ti}$ & -- \\
$1.2 \mathrm{U}$ & -- \\
$1.45-6.23 \mathrm{~W}$ & -- \\
$0.005 \mathrm{Y}$ & $0.001 \mathrm{Y}^{(\mathrm{b})}$ \\
$0.021-0.43 \mathrm{Zr}$ & $1.24-2.9 \mathrm{Zr}$ \\
\hline \hline
\end{tabular}

(a) Nominal composition.

(b) Alloy 109 which showed inhomogeneity. 


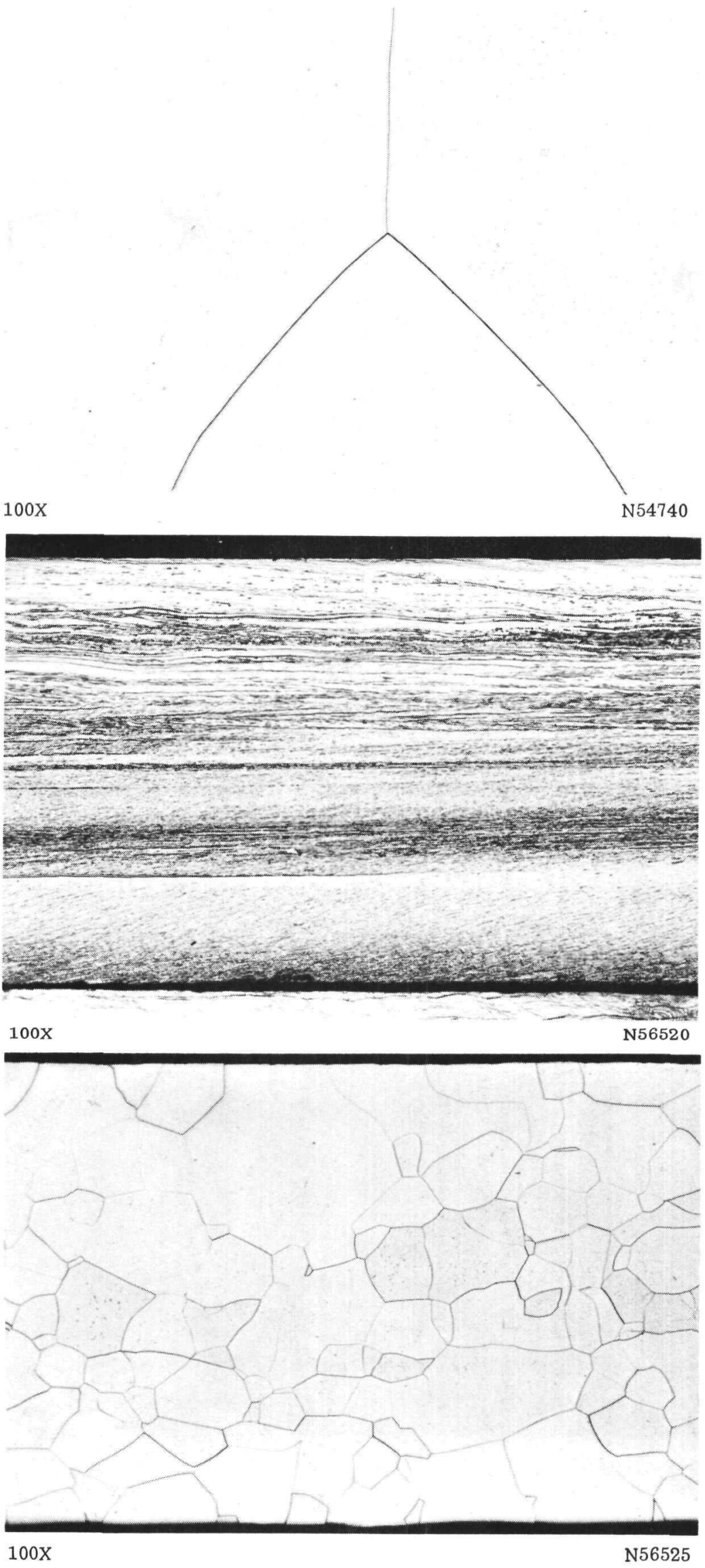

a. As Cast

b. Cold Rolled (90 Per Cent Reduction)

c. Vacuum Annealed $2 \mathrm{Hr}$ at $2600 \mathrm{~F}$ After Cold Rolling

FIGURE 5. TYPICAL MICROSTRUCTURES OF ARC-MELTED HIGH-PURITY TANT ALUM (ALLOY 13) 
Several grain boundaries and areas in the matrix of the tantalum $1.2 \mathrm{w} / \mathrm{o}$ uranium alloy contained a second phase, although most of the alloy was a single-phase structure.

Thorium and zirconium were found to have limited solubility in tantalum. In material arc cast and rapidly cooled, the solubility limit of thorium was greater than 0.061 $\mathrm{w} / \mathrm{o}$ and less than $0.40 \mathrm{w} / \mathrm{o}$. The solid solubility of zirconium in material with a similar history was shown to be greater than $0.43 \mathrm{w} / 0$ and less than $1.3 \mathrm{w} / \mathrm{o}$. The microstructures of the tantalum-thorium alloys, illustrated in Figure 6, contained an inter- and intragranular phase which increased with increased amounts of thorium from 0.4 to 5.6 w/o. Figures 7 and 8 show the microstructures of the tantalum-zirconium alloys in both the as-cast and the as-annealed conditions, respectively. Although the tantalum-0.43 w/o zirconium alloy had a single-phase structure in the as-cast condition (Figure $7 \mathrm{a}$ ), after vacuum annealing at $3000 \mathrm{~F}$ for $1 \mathrm{hr}$ a discontinuous phase was precipitated at the grain boundaries (Figure $8 \mathrm{a}$ ). The $1.3 \mathrm{w} / 0$ zirconium alloy, shown in Figures $7 \mathrm{~b}$ and $8 \mathrm{~b}$, contained a slight discontinuous inter- and intragranular phase in the as-cast condition and significantly more in the annealed condition. Similarly, the as-cast $2.9 \mathrm{w} / \mathrm{o}$ zirconium alloy contained more of what appeared to be the same discontinuous grainboundary phase plus a very slight amount of a phase within the grains (Figure 7a). After annealing at $3000 \mathrm{~F}$ for $\mathrm{l} \mathrm{hr}$, the quantity of grain-boundary phase remained about the same. However, there was an increase in the amount of the intragranular phase (Figure 8c).

The alloy containing $0.01 \mathrm{w} / \mathrm{o}$ beryllium had a relatively small spherical-shaped phase distributed both inter- and intragranularly, as shown in Figure 9a. Also, this alloy contained an area which was segregated and this area appears in Figure 9a. Additions of from 0.5 to $1.0 \mathrm{w} / \mathrm{o}$ boron to tantalum resulted in a eutectic boride phase in the tantalum matrix. The amount of the second phase increased with the boron content. Figure $9 \mathrm{~b}$ illustrates the microstructure of the $1 \mathrm{w} / \mathrm{o}$ boron alloy. As indicated previously, these extremely hard boron alloys could not be fabricated at room temperature. Alloys with from 0.03 to $0.25 \mathrm{w} / 0$ carbon contained fine particles, presumably carbides, at the grain boundaries and within the grains. The quantity of the second phase increased significantly with increasing carbon additions. Figure $9 \mathrm{c}$ shows the structure of the 0.03 w/o carbon alloy, which was the only one that was fabricable, in the as-cast condition. The lack of fabricability of the alloys with more than $0.03 \mathrm{w} / 0$ carbon was attributed to the presence of excessive amounts of intergranular phase.

Although chemical-analysis data showed a recovery of less than 0.03 w/o lanthanum in the alloys with an intended lathanum content of $1 \mathrm{w} / 0$, the microstructure contained a large quantity of an acicular phase in the matrix and a discontinuous grain-boundary precipitate with a depleted zone near the grain boundaries (Figure 10a). Similarly, the tantalum-1. $0 \mathrm{w} / 0$ scandium alloy, which was analyzed as less than $0.10 \mathrm{w} / \mathrm{o}$ scandium, had a large amount of a needlelike phase in the matrix and a discontinuous intergranular precipitate with a depleted zone adjacent to the grain boundaries (Figure 10b). The addiition of 1.0 and $3 \mathrm{w} / \mathrm{o}$ silicon to tantalum produced structures, as shown in Figure $10 \mathrm{c}$, having a very large amount of a eutectic phase similar to that of the boron alloys. The $3 \mathrm{w} / \mathrm{o}$ silicon alloy contained more of this eutectic phase, but the size was smaller. The microstructure of the inhomogeneous yttrium alloy (109) contained areas, as shown in Figure 10d, with a second phase in the matrix and a discontinuous grain-boundary precipitate. 
a. Tantalum-0.4 w/o Thorium (Alloy 89)

b. Tantalum-1.2 w/o Thorium(Alloy 90)
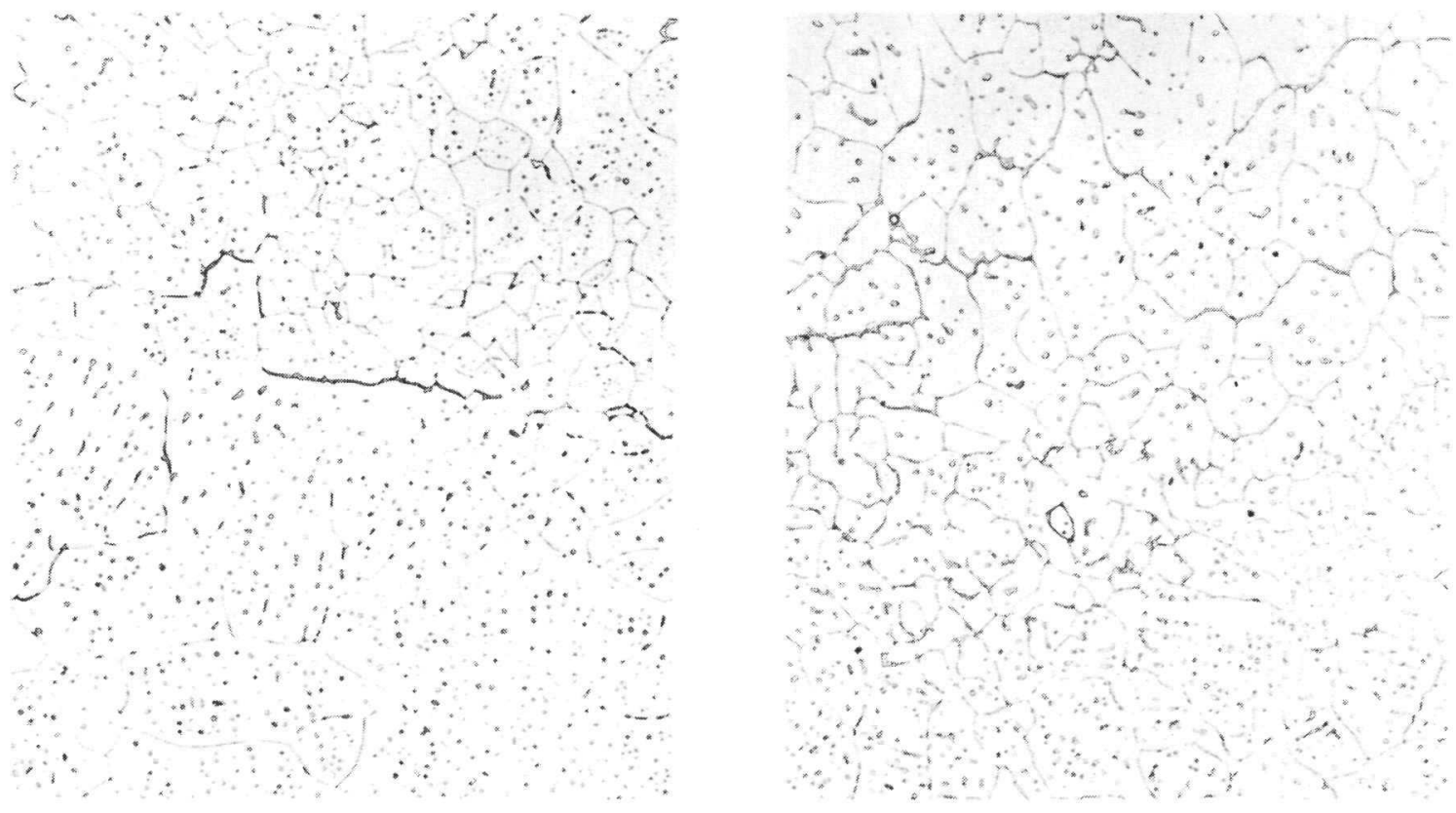

c. Tantalum-2.7 w/o Thorium (Alloy 87 )

d. Tantalum $-5.6 \mathrm{w} / \mathrm{o}$ Thorium (Alloy 88 )

FIGURE 6. MICROSTRUCTURES OF AS-CAST TANT ALUM-THORIUM ALLOYS 
$100 \mathrm{X}$

a. Tantalum-0.43 w/o Zirconium (Alloy 98)

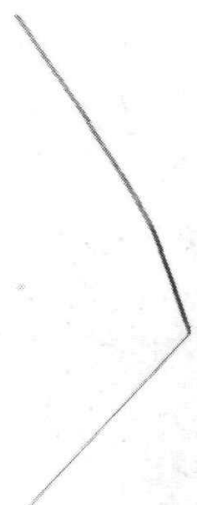

67624

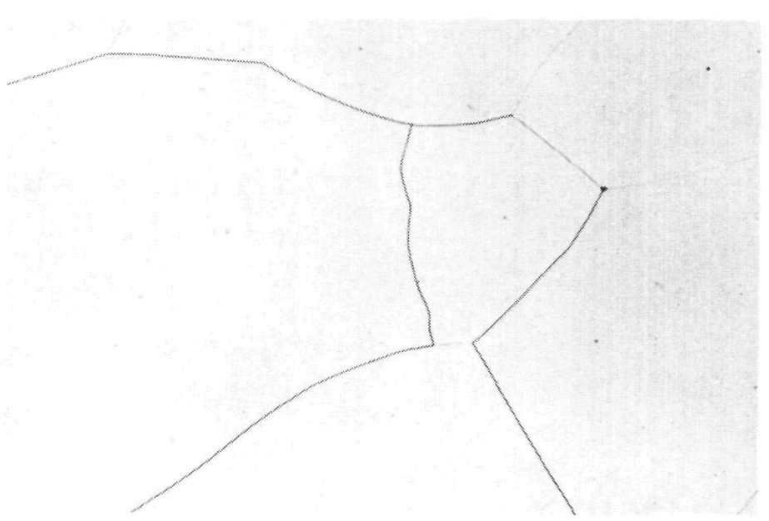

$100 \mathrm{X}$

N67625

b. Tantalum-1.3 w/o Zirconium (Alloy 99)

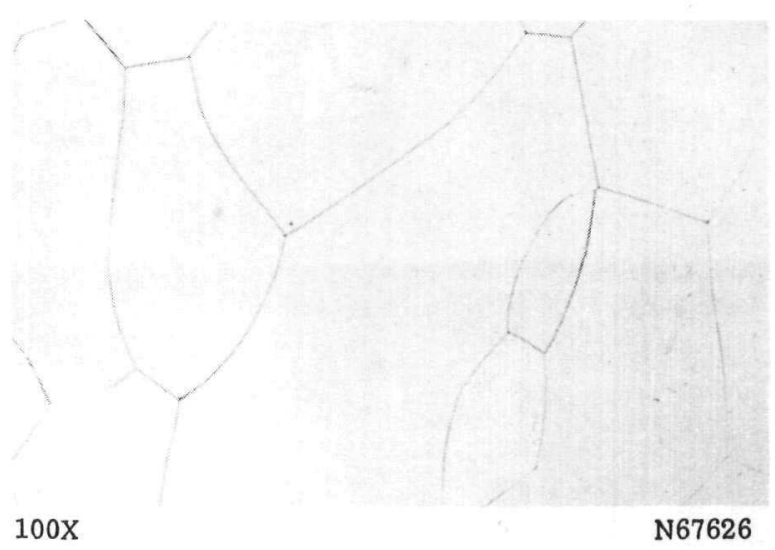

c. Tantalum-2.9 w/o Zirconium (Alloy 100)

FIGURE 7. MICROSTRUCTURES OF AS-CAST TANT ALUM-ZIRCONIUM ALLOYS

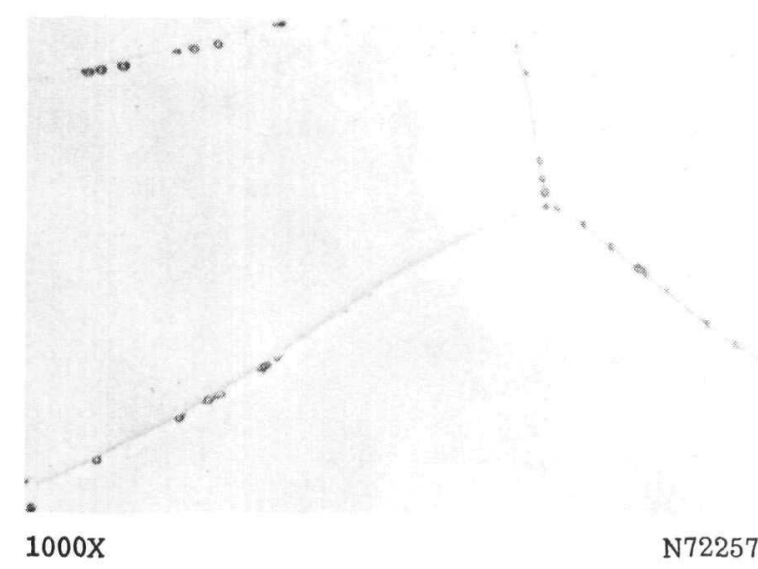

a. Tantalum-0.43 w/o Zirconium (Alloy 98)

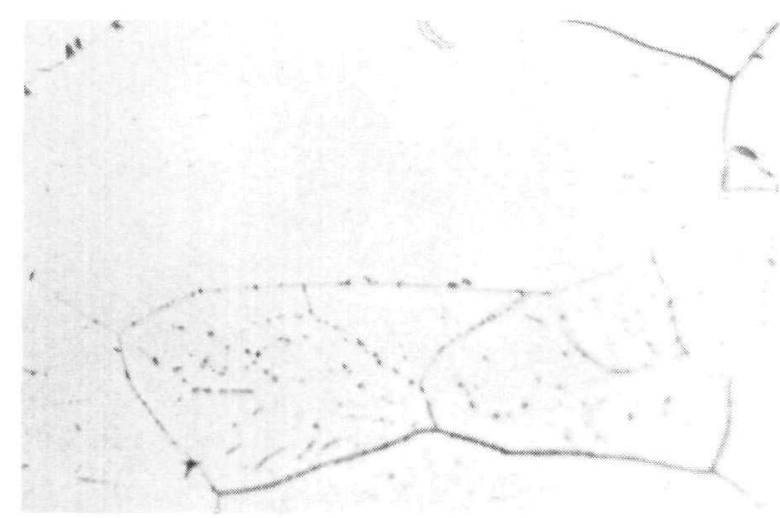

$1000 \mathrm{X}$

N72258

b. Tantalum-1.3 w/o Zirconium (Alloy 99)

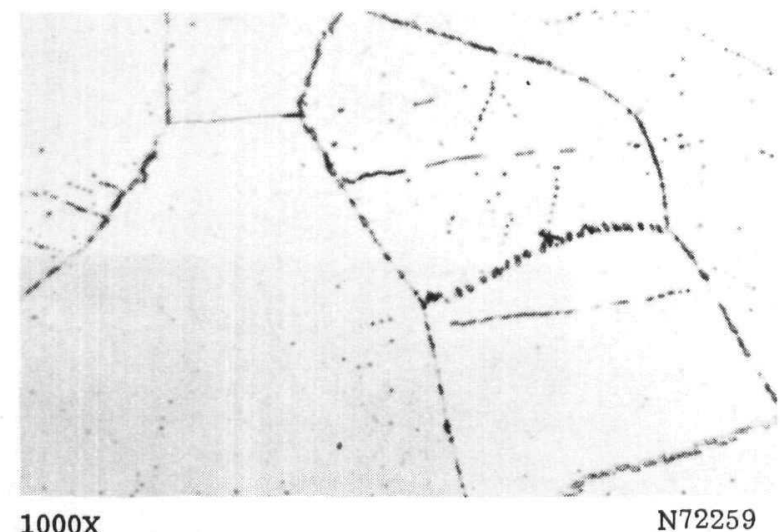

c. Tantalum-2.9 w/o Zirconium (Alloy 100)

FIGURE 8. MICROSTRUCTURES OF TANTALUMZIRCONIUM ALLOYS AFTER VACUUM ANNEALING $1 \mathrm{HR}$ AT $3000 \mathrm{~F}$ 


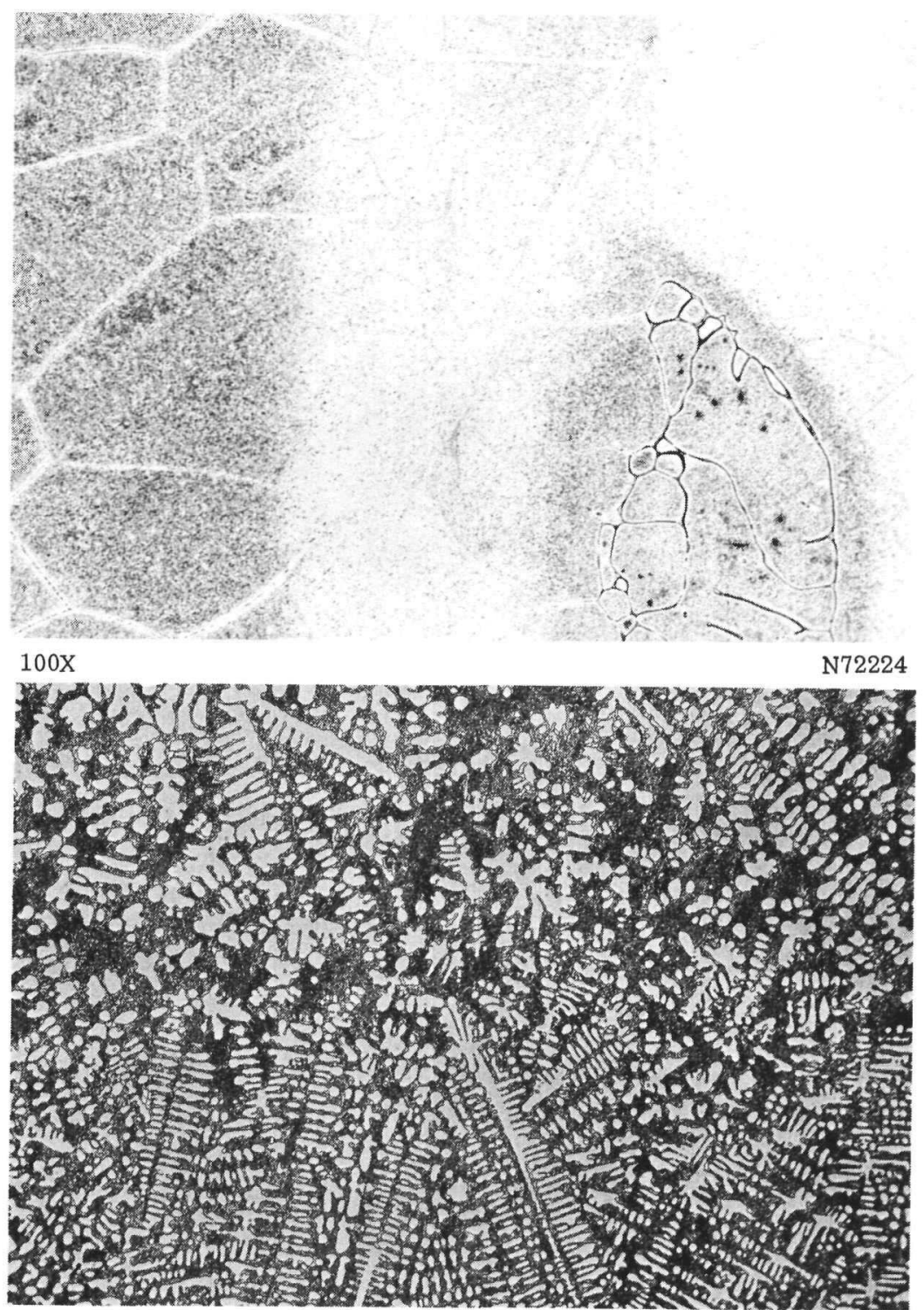

$100 x$

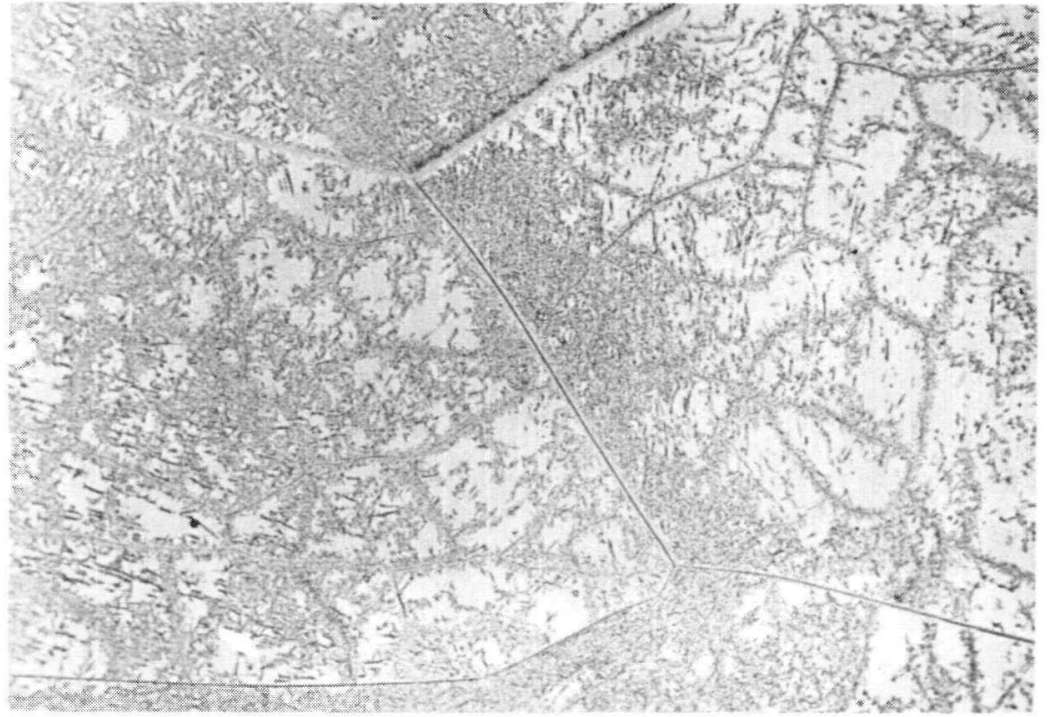

a. Tantalum-0.01 w/o Beryllium

\section{Composition)}

c. Tantalum-0.03 w/o Carbon

FIGURE 9. MICROSTRUCTURES OF AS-CAST TANT ALUM-BASE ALLOYS 


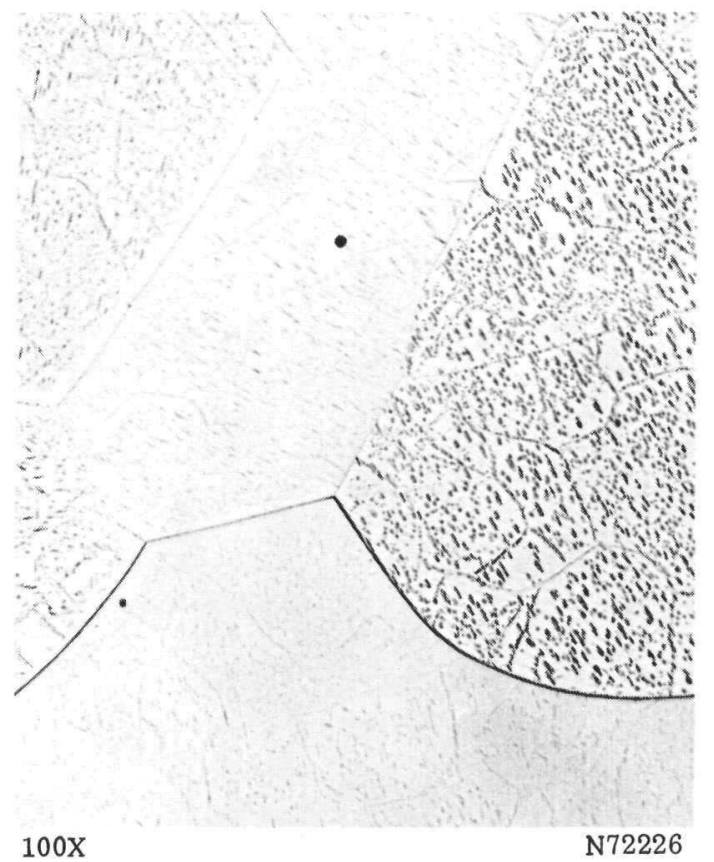

a. Tantalum $-<0.03$ w/o Lanthanum

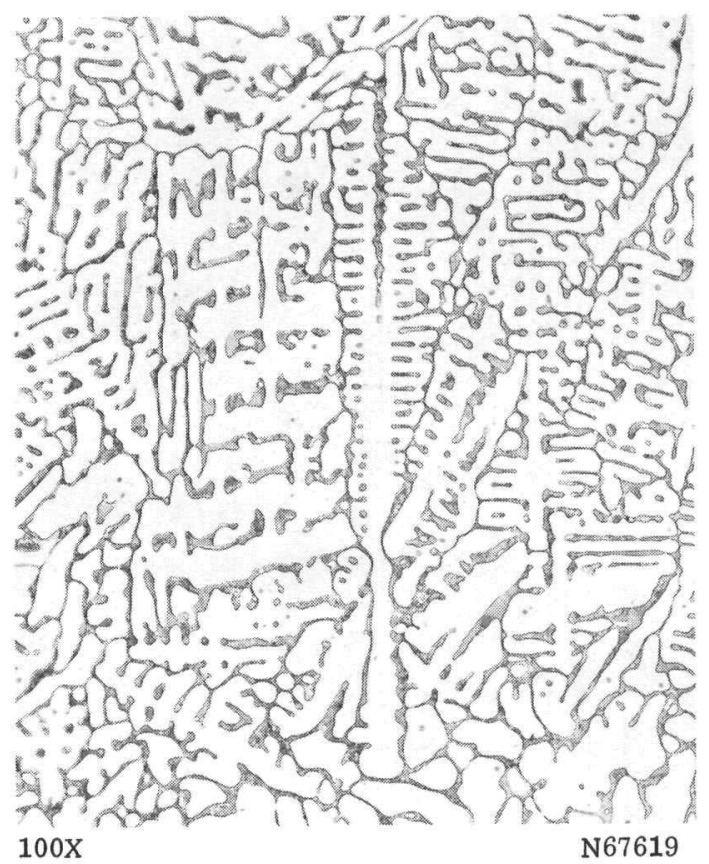

c. Tantalum-1 w/o Silicon (Nominal Composition)

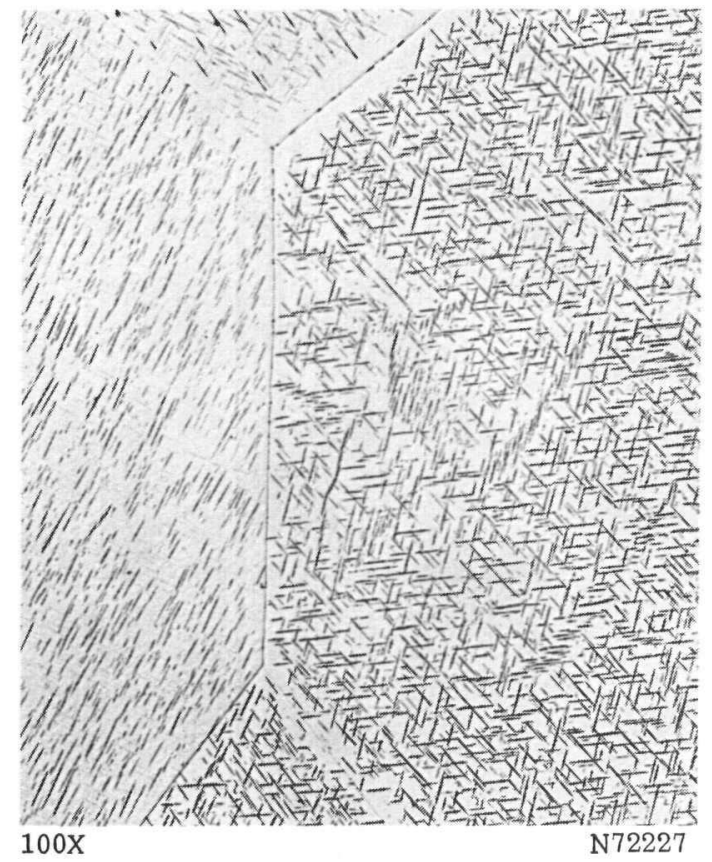

b. Tantalum $-<0.10 \mathrm{w} / 0$ Scandium

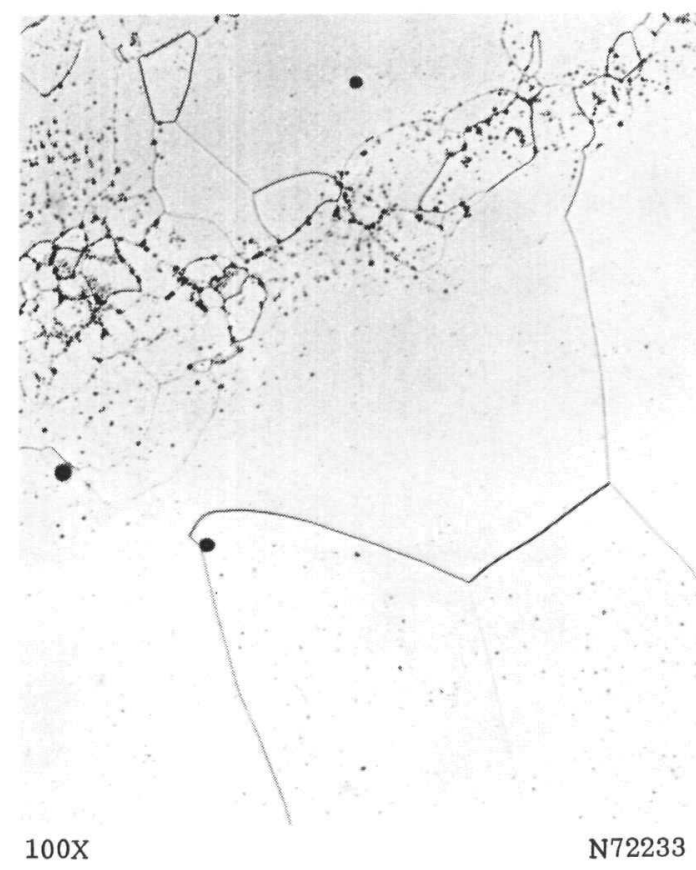

d. Tantalum-0.001 w/o Yttrium (Alloy 109) 


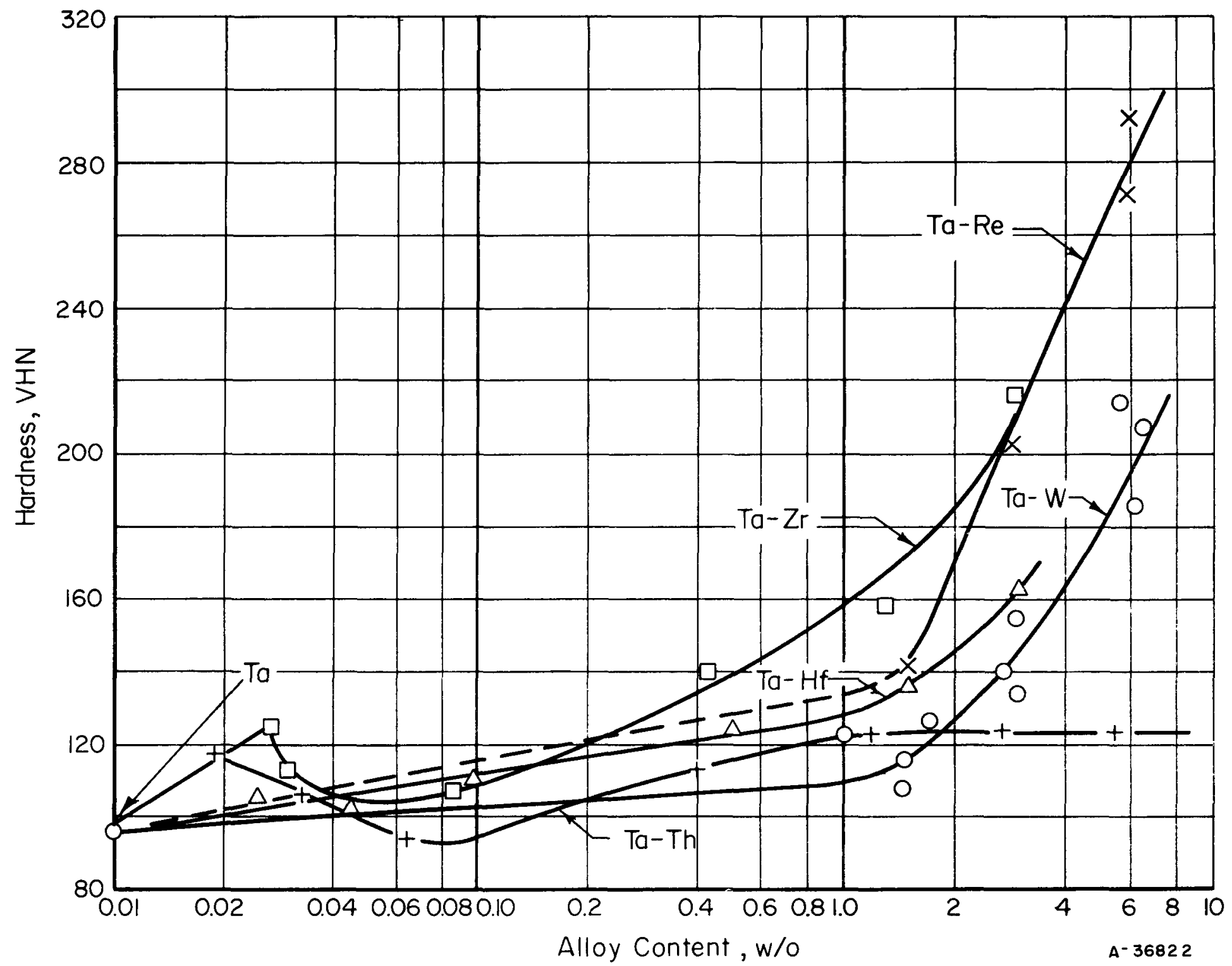

FIGURE 11. EFFECTS OF ALLOYING ON THE HARDNESS OF AS-CAST TANTALUM 
In general, the alloys had homogeneous microstructures when melted by the standard procedure given earlier. However, alloys containing from 1.26 to $2.9 \mathrm{w} / \mathrm{o}$ zirconium and from 1.2 to $5.55 \mathrm{w} / 0$ hafnium had cored structures at the surfaces of the arc-cast buttons. This coring was attributed to the rapid cooling following arc casting. Also, the tantalum $0.01 \mathrm{w} / \mathrm{o}$ beryllium and the tantalum-1. $2 \mathrm{w} / \mathrm{o}$ uranium alloy contained areas of inhomogeneity. The inhomogeneous portion of the tantalum- $0.01 \mathrm{w} / \mathrm{o}$ beryllium alloy is shown in Figure 9a. As mentioned previously, one of the yttrium alloys (109) was inhomogeneous, as shown in Figure lod. However, this alloy was melted mainly for the purpose of recovering a portion of the yttrium rather than for obtaining a homogeneous alloy.

The grain-size data for all of the materials in the as-cast and as-annealed conditions are given in Table 13. A comparison of the effect of alloying on the grain size of the annealed material cannot be made since different annealing treatments were employed. Therefore, all of the following comments on grain size refer to the alloys in the as-cast condition. In general, alloying additions resulted in a refined grain structure. Exceptions were alloys containing additions of $<0.001 \mathrm{w} / \mathrm{o}$ aluminum (Alloy 72 ) $<0.01$ to $0.015 \mathrm{w} / 0$ iron, 0.015 to $0.03 \mathrm{w} / 0$ titanium, and $<0.001 \mathrm{w} / 0$ yttrium (Alloys 37 , $66,67,68$, and 69). The grain size of the yttrium alloys was generally slightly larger than that of unalloyed tantalum. Increasing additions of rhenium, tungsten, and additions of thorium from 0.018 to $0.066 \mathrm{w} / 0$ produced corresponding decreases in grain size. In the case of the hafnium alloys, the grain size decreased with increasing hafnium additions from 0.5 to $1.5 \mathrm{w} / \mathrm{o}$. For the zirconium alloys the grain size remained about the same from 0.021 to $0.10 \mathrm{w} / 0$ zirconium. Then from 0.10 to $2.9 \mathrm{w} / 0$ zirconium the grain size behaved similarly to that of the tungsten and rhenium alloys.

$\underline{\text { Hardness }}$

Table 13 contains the hardness data for most of the materials in three conditions: as cast, as rolled, and as vacuum annealed. In the case of unalloyed tantalum and tantalum-base alloys having the same composition, the differences in hardness were attributed to variations in the impurity levels. A very good illustration of this can be seen in comparing the hardness and analytical data (Table 12) of the unalloyed tantalum specimens of the first series.

Generally speaking, the alloying of tantalum resulted in harder materials. However, the alloys to which the following additions were made had about the same hardness as unalloyed tantalum: $0.5 \mathrm{w} / 0$ aluminum, $2 \mathrm{w} / 0$ cerium, $1.0 \mathrm{w} / \mathrm{o}$ iron, $2 \mathrm{w} / \mathrm{o}$ lanthanum, $1.5 \mathrm{w} / 0$ scandium, $2 \mathrm{w} / 0$ uranium, 0.025 to $2 \mathrm{w} / 0$ titanium, and 0.025 to $3 \mathrm{w} / 0$ yttrium. It is possible and probable that the hardness of tantalum would have been increased by the above elements, excepting uranium which was recovered, if any significant quantities of them had been retained in the tantalum. Additions of boron and silicon to tantalum produced extremely hard alloys, as indicated in Table 13, which could not be fabricated at room temperature. In fact, as mentioned earlier, the $3 \mathrm{w} / \mathrm{o}$ silicon alloy broke into several pieces during casting. The hardness of these alloys increased with the amount of the addition. Figure 11 shows the effect of alloying on the hardness of tantalum. The hardness of alloys with from 0.028 to $0.25 \mathrm{w} / \mathrm{o}$ carbon was about the same, but significantly greater than that of unalloyed tantalum. The high hardness of the tantalum- $0.1 \mathrm{w} / \mathrm{o}$ carbon alloy was believed to have been caused by contamination during melting. Alloys containing from 0.025 to $0.46 \mathrm{w} / \mathrm{o}$ hafnium had about the 
TABLE 13, HARDNESS, GRAIN SIZE, AND FABRICATION BEHAVIOR OF ARC-CAST TANTALUM AND TANTALUM-BASE ALLOYS

\begin{tabular}{|c|c|c|c|c|c|c|c|c|c|}
\hline & \multirow{2}{*}{$\begin{array}{c}\text { Actual } \\
\text { Composition(a) } \\
\text { (Balance Tantalum), } \\
\text { w/o }\end{array}$} & \multicolumn{4}{|c|}{ Hardness, VHN } & \multicolumn{3}{|c|}{ Average Grain Diameter, $\mathrm{mm}$} & \multirow[b]{2}{*}{$\begin{array}{l}\text { Relative } \\
\text { Fabrication } \\
\text { Behavior(b) }\end{array}$} \\
\hline Alloy & & $\begin{array}{l}\text { As } \\
\text { Cast }\end{array}$ & $\begin{array}{c}\text { Cold } \\
\text { Rolled }\end{array}$ & $\begin{array}{l}\text { Vacuum } \\
\text { Annealed }\end{array}$ & $\begin{array}{l}\text { Homogenized, } \\
\text { Cold Rolled } \\
\text { and Annealed }\end{array}$ & $\begin{array}{c}\text { As } \\
\text { Cast }\end{array}$ & $\begin{array}{l}\text { Vacuum } \\
\text { Annealed }\end{array}$ & $\begin{array}{l}\text { Homogenized, } \\
\text { Cold Rolled } \\
\text { and Annealed }\end{array}$ & \\
\hline
\end{tabular}

First Series

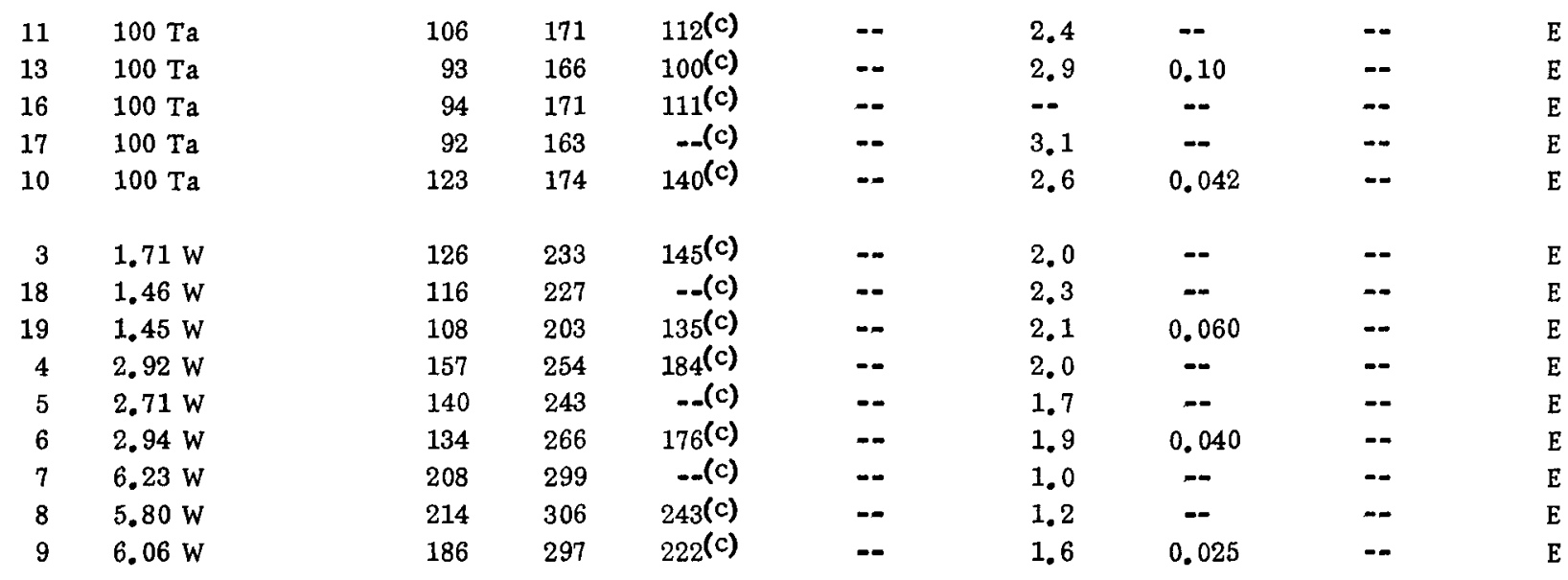

$\underline{\text { Second Series }}$

\begin{tabular}{|c|c|c|c|c|c|c|c|c|c|}
\hline 27 & $100 \mathrm{Ta}$ & 89 & 129 & $86^{(c)}$ & -- & 3.5 & 0.100 & -- & E \\
\hline 28 & $1.5 \mathrm{Re}$ & 141 & 239 & $145^{(d)}$ & $-\infty$ & 2.1 & 0.060 & - & $\mathrm{E}$ \\
\hline 29 & $1.5 \mathrm{Re}$ & 141 & 245 & $139^{(d)}$ & -- & 2.5 & 0.050 & -- & E \\
\hline 30 & $2.85 \mathrm{Re}$ & 208 & 317 & $\infty$ & 206 (d) & 1.6 & - & 0.036 & E \\
\hline 31 & $3.0-2.75 \mathrm{Re}$ & 198 & 290 & 204 (d) & -- & 2.0 & 0.060 & - & E \\
\hline 32 & $6.0 \mathrm{Re}$ & 293 & 387 & $\cdots$ & $-\infty$ & 1.5 & $\ldots$ & -- & $\mathrm{P}$ \\
\hline 33 & $5.5-6.2 \mathrm{Re}$ & 271 & 383 & 264 (d) & -- & 1.6 & 0.036 & -- & $\mathrm{P}$ \\
\hline 35 & $0.031 \mathrm{C}$ & 152 & 187 & $97^{(e)}$ & 93 (c) & 2.8 & 0.036 & 0.042 & E \\
\hline 36 & $0.10 C^{(f)}$ & 267 & 338 & -- & -- & 1.5 & - & - & NF \\
\hline 34 & $0.25 C^{(f)}$ & 143 & 219 & -- & $-\infty$ & 1.3 & - & -- & NF \\
\hline 43 & $0.25 \mathrm{C}^{(f)}$ & 157 & 239 & -- & -- & 0.6 & - & - & NF \\
\hline 38 & $<0.001 \mathrm{Y}$ & 86 & 153 & 85 (c) & $-\infty$ & 2.2 & 0.060 & $=$ & E \\
\hline 39 & $<0.001 \mathrm{Y}$ & 90 & 125 & $80^{(d)}$ & $86^{(d)}$ & 2.5 & - & -- & $\mathrm{E}$ \\
\hline 37 & $<0.001 \mathrm{Y}$ & 117 & 203 & $114^{(d)}$ & -- & 5.8 & 0.120 & -- & E \\
\hline
\end{tabular}

Third Series

\begin{tabular}{|c|c|c|c|c|c|c|c|c|}
\hline 44 & $100 \mathrm{Ta}$ & 100 & 178 & $119(e)$ & -- & 2.4 & 0.06 & $-\infty$ \\
\hline 46 & $0.025-0.026 \mathrm{Hf}$ & 106 & 154 & $112(g)$ & -- & 2.0 & 0.05 & - \\
\hline 47 & $0.043-0.046 \mathrm{Hf}$ & 102 & 150 & $102(g)$ & -- & 1.6 & 0.04 & - \\
\hline 52 & $0.096-0.10 \mathrm{Hf}$ & 111 & 176 & $100(e)$ & -- & 1.7 & 0.04 & - \\
\hline 49 & $1.20-1.30 \mathrm{Hf}$ & 103 & 280 & $170(e)$ & -- & 0.8 & 0.04 & $-\infty$ \\
\hline 50 & $2.70 \mathrm{Hf}$ & 222 & 267 & $150(g)$ & -- & 0.4 & 0.04 & - \\
\hline 56 & $5.25-5.55 \mathrm{Hf}$ & 170 & 255 & $148(e)$ & -- & 0.4 & 0.05 & $-\infty$ \\
\hline
\end{tabular}


TABLE 13. (Continued)

\begin{tabular}{|c|c|c|c|c|c|c|c|c|c|}
\hline \multirow{2}{*}{\multicolumn{2}{|c|}{$\begin{array}{c}\text { Actual } \\
\text { Composition(a) } \\
\text { (Balance Tantalum), } \\
\text { w/o }\end{array}$}} & \multicolumn{4}{|c|}{ Hardness, VHN } & \multicolumn{3}{|c|}{ Average Grain Diameter, $\mathrm{mm}$} & \multirow[b]{2}{*}{$\begin{array}{l}\text { Relative } \\
\text { Fabrication } \\
\text { Behavior(b) }\end{array}$} \\
\hline & & $\begin{array}{c}\text { As } \\
\text { Cast }\end{array}$ & $\begin{array}{l}\text { Cold } \\
\text { Rolled }\end{array}$ & $\begin{array}{l}\text { Vacuum } \\
\text { Annealed }\end{array}$ & $\begin{array}{l}\text { Homogenized, } \\
\text { Cold Rolled } \\
\text { and Annealed }\end{array}$ & $\begin{array}{c}\text { As } \\
\text { Cast }\end{array}$ & $\begin{array}{l}\text { Vacuum } \\
\text { Annealed }\end{array}$ & $\begin{array}{l}\text { Homugenized, } \\
\text { Cold Rolled } \\
\text { and Annealed }\end{array}$ & \\
\hline
\end{tabular}

Third Series (Continued)

\begin{tabular}{|c|c|c|c|c|c|c|c|c|}
\hline 53 & $0.033-0.021 \mathrm{ZI}$ & 125 & 198 & $100(e)$ & -- & 1.7 & 0.05 & -- \\
\hline 54 & $0.027-0.033 \mathrm{Zr}$ & 113 & 164 & $99(\mathrm{~h})$ & $-\infty$ & 2.0 & 0.06 & -- \\
\hline 55 & $0.10-0.071 \mathrm{Zr}$ & 107 & 175 & $82(e)$ & -- & 1.9 & 0.06 & - \\
\hline 51 & $1.26-1.24 \mathrm{Zr}$ & 198 & 246 & $196(1)$ & $-\infty$ & 0.4 & 0.04 & -- \\
\hline 57 & $2.75-2.65 \mathrm{Zr}$ & 245 & 267 & $168(e)$ & -- & 0.4 & 0.04 & - \\
\hline 59 & $0.024-0.015 \mathrm{Ti}$ & 86 & 159 & $82(e)$ & $-\infty$ & 2.0 & 0.14 & $\sim$ \\
\hline 60 & $0.027-0.004 \mathrm{Ti}$ & 111 & 143 & $72(e)$ & - & 2.2 & 0.14 & $\cdots$ \\
\hline 61 & $0.030 \mathrm{Ti}$ & 98 & 156 & $73(e)$ & - & 3.1 & 0.20 & $\boldsymbol{m}$ \\
\hline 62 & $0.019-0.018 \mathrm{Th}$ & 117 & 163 & $131^{(j)}$ & -- & 1.8 & -- & -- \\
\hline 63 & $0.031-0.034 \mathrm{Th}$ & 106 & 163 & $132^{(i)}$ & -- & 1.5 & 0.10 & $-\infty$ \\
\hline 64 & $0.066-0.061 \mathrm{Th}$ & 94 & 151 & $109(j)$ & - & 1.2 & 0.06 & -- \\
\hline 65 & $2.90-2.50 \mathrm{~W}$ & 129 & 219 & $138(e)$ & $-\infty$ & 1.5 & $-\infty$ & $\cdots$ \\
\hline 66 & $<0.001 \mathrm{Y}$ & 100 & 154 & $89(\mathrm{~h})$ & -- & 2.9 & 0.10 & - \\
\hline 67 & $<0.001 \mathrm{Y}$ & 94 & 129 & $86(\mathrm{~h})$ & $-\infty$ & 3.1 & 0.07 & - \\
\hline 68 & $<0.001 Y$ & 100 & 152 & $131(\mathrm{~h})$ & $=-$ & 2.5 & 0.14 & -- \\
\hline 69 & $<0,001 \mathrm{Y}$ & 100 & 152 & $106(\mathrm{~h})$ & $-\infty$ & 3.5 & 0.06 & -- \\
\hline
\end{tabular}

Fourth Series (Group 1)

\begin{tabular}{|c|c|c|c|c|c|c|c|c|c|}
\hline 102 & $100 \mathrm{Ta}$ (control) & 94 & 165 & -- & -- & 3.4 & - & -- & $\mathrm{E}$ \\
\hline 103 & $100 \mathrm{Ta}$ (control) & 105 & 190 & -- & -- & 4.2 & -- & - & E \\
\hline 85 & $0.005 \mathrm{Y}$ & 94 & 147 & $-\infty$ & -- & 1.6 & -- & -- & $\mathrm{E}$ \\
\hline 89 & $0.4 \mathrm{Th}$ & 113 & 172 & -- & $\boldsymbol{m}$ & - & - & - & $\mathbf{P}$ \\
\hline 90 & $1.2 \mathrm{Th}$ & 123 & 171 & -- & -- & -- & -- & $-\infty$ & P \\
\hline 87 & $2.7 \mathrm{Th}$ & 124 & 203 & -- & -- & $=$ & - & - & P \\
\hline 88 & $5.6 \mathrm{Th}$ & 123 & 192 & -- & -- & $\cdots$ & - & $-\infty$ & $\mathrm{P}$ \\
\hline 91 & $<0.01 \mathrm{Fe}$ & 98 & 165 & $\cdots$ & - & 3.8 & -- & - & F \\
\hline 92 & $0.015 \mathrm{Fe}$ & 123 & 198 & - & $-\infty$ & 3.9 & -- & $\cdots$ & F \\
\hline 93 & $1.0 \mathrm{Si}(\mathrm{f})$ & 596 & $-\infty$ & - & - & -- & - & - & NF \\
\hline 94 & $3.0 \mathrm{Si}^{(f)}$ & 720 & -- & -- & - & -- & -- & -- & NF \\
\hline 95 & $0.5 \mathrm{Hf}$ & 124 & 192 & $112^{(k)}$ & - & 2.4 & - & -- & $\mathrm{E}$ \\
\hline 96 & $1.5 \mathrm{Hf}$ & 136 & 214 & $110^{(k)}$ & -- & 1.2 & - & - & $\mathrm{E}$ \\
\hline 97 & $3.0 \mathrm{Hf}$ & 163 & 251 & $149(k)$ & - & 1.2 & - & -- & $\mathrm{E}$ \\
\hline 98 & $0.43 \mathrm{Zr}$ & 140 & 197 & $135(\mathrm{k})$ & $=-$ & 1.3 & -- & -- & E \\
\hline 99 & $1.30 \mathrm{Zr}$ & 158 & 257 & $166^{(k)}$ & -- & 0.33 & - & -- & E \\
\hline 100 & $2.90 \mathrm{Zr}$ & 216 & 293 & $210^{(k)}$ & $=$ & 0.23 & -- & - & $\mathbf{P}$ \\
\hline
\end{tabular}


TABLE 13. (Continued)

\begin{tabular}{|c|c|c|c|c|c|c|c|c|c|}
\hline \multirow[b]{2}{*}{ Alloy } & \multirow{2}{*}{$\begin{array}{c}\text { Actual } \\
\text { Composition(a) } \\
\text { (Balance Tantalum), } \\
\text { w/o }\end{array}$} & \multicolumn{4}{|c|}{ Hardness, VHN } & \multicolumn{3}{|c|}{ Average Grain Diameter, $\mathrm{mm}$} & \multirow[b]{2}{*}{$\begin{array}{c}\text { Relative } \\
\text { Fabrication } \\
\text { Behavior }(\mathrm{b})\end{array}$} \\
\hline & & $\begin{array}{c}\text { As } \\
\text { Cast }\end{array}$ & $\begin{array}{l}\text { Cold } \\
\text { Rolled }\end{array}$ & $\begin{array}{c}\text { Vacuum } \\
\text { Annealed }\end{array}$ & $\begin{array}{l}\text { Homogenized, } \\
\text { Cold Rolled } \\
\text { and Annealed }\end{array}$ & $\begin{array}{c}\text { As } \\
\text { Cast }\end{array}$ & $\begin{array}{c}\text { Vacuum } \\
\text { Annealed }\end{array}$ & $\begin{array}{l}\text { Homogenized, } \\
\text { Cold Rolled } \\
\text { and Annealed }\end{array}$ & \\
\hline \multicolumn{10}{|c|}{ Fourth Series (Group 2) } \\
\hline 104 & $100 \mathrm{Ta}$ (control) & 107 & 193 & -- & -- & 3.2 & -- & -- & G \\
\hline 105 & $100 \mathrm{Ta}$ (control) & 78 & 120 & -- & $-\infty$ & 3.0 & -- & -- & $G$ \\
\hline 71 & $<0.001 \mathrm{Al}$ & 98 & 177 & --1 & -- & 2.3 & -- & -- & $\mathrm{E}$ \\
\hline 72 & $<0.001 \mathrm{Al}$ & 134 & 171 & - & -- & 3.0 & -- & -- & $G$ \\
\hline 73 & $0.5 \mathrm{~B}(\mathrm{f})$ & 288 & - & -- & - & -- & - & -- & $\mathrm{NF}$ \\
\hline 74 & $1.0 \mathrm{~B}(\mathrm{f})$ & 376 & -- & -- & -- & -- & - & -- & $\mathrm{NF}$ \\
\hline 76 & $0.01 \mathrm{Be}$ & 147 & 208 & -- & -- & -- & - & $-\infty$ & $\mathrm{F}$ \\
\hline 78 & $<0.10 \mathrm{Ce}$ & 81 & 139 & - & -- & 2.1 & -- & $\cdots$ & $\mathrm{F}$ \\
\hline 80 & $<0.03 \mathrm{La}$ & 100 & 162 & -- & -- & 0.88 & -- & $\cdots$ & $F$ \\
\hline 82 & $<0.10 \mathrm{Sc}$ & 105 & 179 & -- & -- & 1.7 & -- & -- & G \\
\hline 84 & $1.2 \mathrm{U}$ & 109 & 186 & -- & -- & 1.65 & -- & -- & G \\
\hline 86 & $0.01 \mathrm{~T} i$ & 85 & 168 & -- & - & 0.82 & -- & -- & G \\
\hline 101 & $0.34 \mathrm{Ti}$ & 116 & 187 & -- & -- & 1.3 & -- & - & $G$ \\
\hline 109 & $0.001 \mathrm{Y}$ & 96 & 161 & - & -- & -- & -. & -- & $\mathrm{F}$ \\
\hline 110 & $<0.001 \mathrm{Y}$ & 150 & 181 & -- & -- & 0.68 & $=-$ & -- & $\mathrm{E}$ \\
\hline
\end{tabular}

(a) In cases where two compositions are given, the first is the analysis of annealed material and the second is that of as-rolled material.

(b) $E=$ excellent; $G=$ good, $F=$ fair; $P=$ poor; $N F=$ not fabricable.

(c) Vacuum annealed $2 \mathrm{hr}$ at $2600 \mathrm{~F}$.

(d) Vacuum annealed $1 \mathrm{hr}$ at $2600 \mathrm{~F}$ and $1 \mathrm{hr}$ at $2700 \mathrm{~F}$.

(e) Vacuum annealed $1 \mathrm{hr}$ at $2600 \mathrm{~F}$.

(f) Nominal composition.

(g) Vacuum annealed $2 \mathrm{hr}$ at $2600 \mathrm{~F}$ and $1 \mathrm{hr}$ at $2750 \mathrm{~F}$.

(h) Vacuum annealed $2 \mathrm{hr}$ at $2600 \mathrm{~F}, 1 \mathrm{hr}$ at $2750 \mathrm{~F}, 1 \mathrm{hr}$ at $2900 \mathrm{~F}$, cold rolled specimens from 0.030 to $0.025 \mathrm{in} .$, and annealed $1 \mathrm{hr}$ at $2900 \mathrm{~F}$.

(i) Vacuum annealed $2 \mathrm{hr}$ at $2600 \mathrm{~F}, 1 \mathrm{hr}$ at $2750 \mathrm{~F}$, and $1 \mathrm{hr}$ at $2900 \mathrm{~F}$.

(j) Vacuum annealed $2 \mathrm{hr}$ at $2600 \mathrm{~F}, 1 \mathrm{hr}$ at $2750 \mathrm{~F}, 1 \mathrm{hr}$ at $2900 \mathrm{~F}$, cold rolled specimens from 0.030 to $0.025 \mathrm{in} .$, and annealed $2 \mathrm{hr}$ at $2900 \mathrm{~F}$.

(k) Vacuum annealed $1 \mathrm{hr}$ at $3000 \mathrm{~F}$. 
same hardness as tantalum. However, additions of from 0.096 to $5.55 \mathrm{w} / 0$ hafnium produced progressively harder alloys. The effect of thorium and zirconium on the hardness of tantalum was very interesting. The initial addition of $0.018 \mathrm{w} / 0$ thorium and $0.027 \mathrm{w} / 0$ zirconium caused an increase in hardness. Then, increasing the additions to $0.064 \mathrm{w} / 0$ thorium and $0.085 \mathrm{w} / 0$ zirconium produced a decrease in hardness. Further additions of from 0.4 to $1.2 \mathrm{w} / 0$ thorium or from 0.43 to $2.9 \mathrm{w} / 0$ zirconium resulted in progressively harder materials. Thus, it appeared that thorium and zirconium acted first as scavengers of impurities and then as hardeners.

The hardness of alloys with either rhenium or tungsten increased almost linearly with increasing amounts of these elements, as shown in Figure 11.

The effect of cold deformation on the hardness of unalloyed tantalum and tantalumtungsten alloys was shown previously in Table 8 and Figure 2. Also, the effect of annealing temperature on the hardness of tantalum and some of the tantalum-base alloys was illustrated in Tables 9 and 10 and Figure 3.

\section{$\underline{\text { Tensile Properties }}$}

The room-temperature tensile properties were determined on alloys for which sufficient material was available. The tensile tests were generally performed on vacuum-annealed material, but some tests were conducted on tantalum and tantalumtungsten alloys in the cold-rolled condition to determine the effect of rolling.

Table 14 summarizes the tensile properties of all the unalloyed tantalum and the tantalum-base alloys, and Figures 12, 13, and 14 show the effect of a few of the alloying additions on the tensile properties. These data indicate that, in general, the strength of tantalum was increased by alloying, accompanied by slight to large losses in ductility. Low yield and ultimate tensile strengths and high ductility were characteristic of the high-purity annealed tantalum. The ultimate strength of the cold-rolled tantalum $(90$ per cent reduction) was about twice that of the annealed material, but the ductility was reduced about six to seven times. The addition of from 1.46 to $6.23 \mathrm{w} / \mathrm{o}$ tungsten increased the strength linearly, as shown in Figure 12. The yield and ultimate strengths of vacuum-annealed material were more than doubled by the addition of $6.23 \mathrm{w} / \mathrm{o}$ tungsten and the ductility was reduced by half. The tensile strength of tungsten alloys in the coldrolled condition was about twice that of the annealed material as it was in the case of the unalloyed tantalum. The ductility of the cold-rolled tungsten alloys was reduced about 11 times. For example, the ductility of one of the $1.46 \mathrm{w} / \mathrm{o}$ tungsten alloys was reduced from 44 to 4 per cent. Zirconium was found to be the most effective strengthener of tantalum. The tensile strength of the zirconium alloys increased significantly and almost linearly with increasing amounts of zirconium from 0.43 to $2.9 \mathrm{w} / \mathrm{o}$, while the ductility decreased only slightly. As indicated in Table 14, the strength of the $1.3 \mathrm{w} / \mathrm{o}$ zirconium alloy was about 1-3/4 times that of tantalum. It should be pointed out that the annealing temperatures for the two groups of zirconium alloys were different as indicated in Table 14. The high strength of Alloy 51 is probably attributable to the fact that it was only partially recrystallized.

The alloys containing rhenium were found to have the second highest strength. The tensile strength of the annealed $1.5 \mathrm{w} / \mathrm{o}$ rhenium alloy was about $1-1 / 2$ times that of tantalum. There was a linear increase in the ultimate strength and a linear decrease in the ductility as the rhenium content was increased from 1.5 to $6 \mathrm{w} / \mathrm{o}$. 
TABLE 14. ROOM-TEMPERATURE TENSLLE PROPERTIES OF ARC-MELTED HIGH-PURITY TANT ALUM AND TANTALUM-BASE ALLOYS

0.030-In. Strip Specimens

\begin{tabular}{|c|c|c|c|c|c|c|c|}
\hline \multirow[b]{2}{*}{ Alloy } & \multirow{2}{*}{$\begin{array}{c}\text { Actual } \\
\text { Composition } \\
\text { (Balance Tantalum), } \\
\text { w/o }\end{array}$} & \multicolumn{2}{|c|}{ Annealing Conditions } & \multirow[b]{2}{*}{$\begin{array}{c}\text { Hardness, } \\
\text { VHN }\end{array}$} & \multirow{2}{*}{$\begin{array}{c}0.2 \text { Per Cent } \\
\text { Offset Yield } \\
\text { Strength, } \\
1000 \mathrm{psi} \\
\end{array}$} & \multirow{2}{*}{$\begin{array}{l}\text { Ultimate } \\
\text { Tensile } \\
\text { Strength, } \\
1000 \text { psi }\end{array}$} & \multirow{2}{*}{$\begin{array}{l}\text { Elongatior } \\
\text { in } 1 \text { In., } \\
\text { per cent }\end{array}$} \\
\hline & & $\begin{array}{l}\text { Temperature, } \\
\mathrm{F}\end{array}$ & $\begin{array}{c}\text { Time, } \\
\mathrm{hr}\end{array}$ & & & & \\
\hline \multicolumn{8}{|c|}{ First Series $(a)$} \\
\hline \multicolumn{8}{|c|}{ As-Cold-Rolled Specimens (90 Per Cent Reduction) } \\
\hline 16 & $100 \mathrm{Ta}$ & -- & -- & 171 & 72.6 & 74.7 & 5 \\
\hline 17 & $100 \mathrm{Ta}$ & -- & -- & 163 & 71.9 & 75.3 & 5 \\
\hline 18 & $1.46 \mathrm{~W}$ & -- & -- & 227 & 97.9 & 100.5 & 4 \\
\hline 5 & $2.71 \mathrm{~W}$ & -- & -- & 243 & 95.7 & 99 & 2 \\
\hline 7 & $6.23 \mathrm{~W}$ & -- & $-\cdot$ & 299 & 116 & 139 & 3 \\
\hline \multicolumn{8}{|c|}{ Vacuum-Annealed Specimens } \\
\hline 11 & $100 \mathrm{Ta}$ & 2600 & 1 & -- & 30.5 & 38.2 & 44 \\
\hline 13 & $100 \mathrm{Ta}$ & 2600 & 1 & -- & 22.8 & 34 & 35 \\
\hline 17 & $100 \mathrm{Ta}$ & 2600 & 1 & -- & 24.7 & 33.7 & 30 \\
\hline 3 & $1.71 \mathrm{~W}$ & 2600 & 1 & -- & 34.6 & 47 & 35 \\
\hline 18 & $1.46 \mathrm{~W}$ & 2600 & 1 & -- & 31.5 & 45 & 44 \\
\hline 19 & $1.45 \mathrm{~W}$ & 2600 & 1 & -- & 27.1 & 41.8 & 38 \\
\hline 4 & $2.92 \mathrm{~W}$ & 2600 & 1 & -- & 43.4 & 54.8 & 29 \\
\hline 5 & $2.71 \mathrm{~W}$ & 2600 & 1 & -- & 36.8 & 51.5 & 38.5 \\
\hline 6 & $2.94 \mathrm{~W}$ & 2600 & 1 & -- & 36.4 & 51 & 37 \\
\hline 7 & $6.23 \mathrm{~W}$ & 2600 & 1 & -- & 63.1 & 74.8 & 23 \\
\hline 8 & $5.80 \mathrm{~W}$ & 2600 & 1 & -- & 69.1 & 79.5 & 10 \\
\hline 9 & $6.06 \mathrm{~W}$ & 2600 & 1 & -- & 59.7 & 71 & 15 \\
\hline \multicolumn{8}{|c|}{$\underline{\text { Second Series }}^{(b)}$} \\
\hline 29 & $1.5 \mathrm{Re}$ & 2600 & 1 & -- & 43.4 & 57.2 & 26 \\
\hline 30 & $2.85 \mathrm{Re}$ & 2600 & 1 & -- & 76.3 & 86.5 & 14 \\
\hline $32^{(c)}$ & $6.0 \mathrm{Re}$ & 2600 & 1 & $=-$ & 115.3 & 117.6 & 5 \\
\hline \multicolumn{8}{|c|}{ Third Series (b) } \\
\hline 49 & $1.46 \mathrm{Hf}$ & 2600 & 1 & $159-179$ & 56.3 & 75.5 & 19 \\
\hline 50 & $2.65 \mathrm{Hf}$ & 2600 & 1 & $149-170$ & 52.8 & 73.1 & 22 \\
\hline 56 & $6.7 \mathrm{Hf}$ & 2600 & 1 & $154-165$ & 55.6 & 69 & 31 \\
\hline${ }_{51}{ }^{(c)}$ & $1.26 \mathrm{Zr}$ & 2600 & 1 & $151-177$ & 53.9 & 74.6 & 16 \\
\hline 57 & $2.75 \mathrm{Zr}$ & 2600 & 1 & $171-187$ & 63.3 & 77.6 & 26 \\
\hline
\end{tabular}


TABLE 14. (Continued)

\begin{tabular}{|c|c|c|c|c|c|c|c|}
\hline \multirow[b]{2}{*}{ Alloy } & \multirow{2}{*}{$\begin{array}{c}\text { Actual } \\
\text { Composition } \\
\text { (Balance Tantalum), } \\
\text { w/o } \\
\end{array}$} & \multicolumn{2}{|c|}{ Annealing Conditions } & \multirow[b]{2}{*}{$\begin{array}{c}\text { Hardness, } \\
\text { VHN }\end{array}$} & \multirow{2}{*}{$\begin{array}{l}0.2 \text { Per Cent } \\
\text { Offset Yield } \\
\text { Strength, } \\
1000 \mathrm{psi}\end{array}$} & \multirow{2}{*}{$\begin{array}{l}\text { Ultimate } \\
\text { Tensile } \\
\text { Strength, } \\
1000 \mathrm{psi} \\
\end{array}$} & \multirow{2}{*}{$\begin{array}{l}\text { Elongation } \\
\text { in } 1 \text { In., } \\
\text { per cent }\end{array}$} \\
\hline & & $\begin{array}{c}\text { Temperature, } \\
\mathrm{F} \\
\end{array}$ & $\begin{array}{c}\text { Time, } \\
\mathrm{hr}\end{array}$ & & & & \\
\hline \multicolumn{8}{|c|}{ Fourth Series } \\
\hline $103^{(b)}$ & $100 \mathrm{Ta}$ & 2600 & 1 & $99-107$ & 32 & 37.2 & 21 \\
\hline $90^{(a)}$ & $1.2 \mathrm{Th}$ & (d) & (d) & $115-128$ & 32.9 & 49.6 & 14 \\
\hline $87^{(a)}$ & $2.7 \mathrm{Th}$ & (d) & (d) & $113-127$ & 33.8 & 55 & 13 \\
\hline $91^{(a)}$ & $<0.01 \mathrm{Fe}$ & 2600 & 1 & $89-96$ & 29.3 & 36.5 & 15 \\
\hline $92^{(a)}$ & $0.015 \mathrm{Fe}$ & 2600 & 1 & $109-113$ & 34.5 & 40 & 17 \\
\hline 95 (b) & $0.5 \mathrm{Hf}$ & 3000 & 1 & $119-122$ & 37.7 & 48.1 & 24 \\
\hline $96^{(\mathrm{b})}$ & $1.5 \mathrm{Hf}$ & 3000 & 1 & $107-116$ & 34.8 & 49.3 & 25 \\
\hline $97^{(b)}$ & $3.0 \mathrm{Hf}$ & 3000 & 1 & $143-178$ & 48.8 & 62.1 & 22 \\
\hline $98^{(b)}$ & $0.43 \mathrm{Zr}$ & 3000 & 1 & $122-126$ & 39.9 & 50.9 & 18 \\
\hline $99^{(b)}$ & $1.3 \mathrm{Zr}$ & 3000 & 1 & $138-153$ & 46.7 & 61.8 & 24 \\
\hline $1.00(a)$ & $2.9 \mathrm{Zr}$ & 3000 & 1 & $198-226$ & 71.4 & 86.3 & 18 \\
\hline
\end{tabular}

(a) Results based on average of duplicate specimens per composition.

(b) Results based on average of triplicate specimens per composition.

(c) Not fully recrystallized.

(d) Annealed $1 \mathrm{hr}$ at $2900 \mathrm{~F}$ plus $1 \mathrm{hr} 3200 \mathrm{~F}$. 


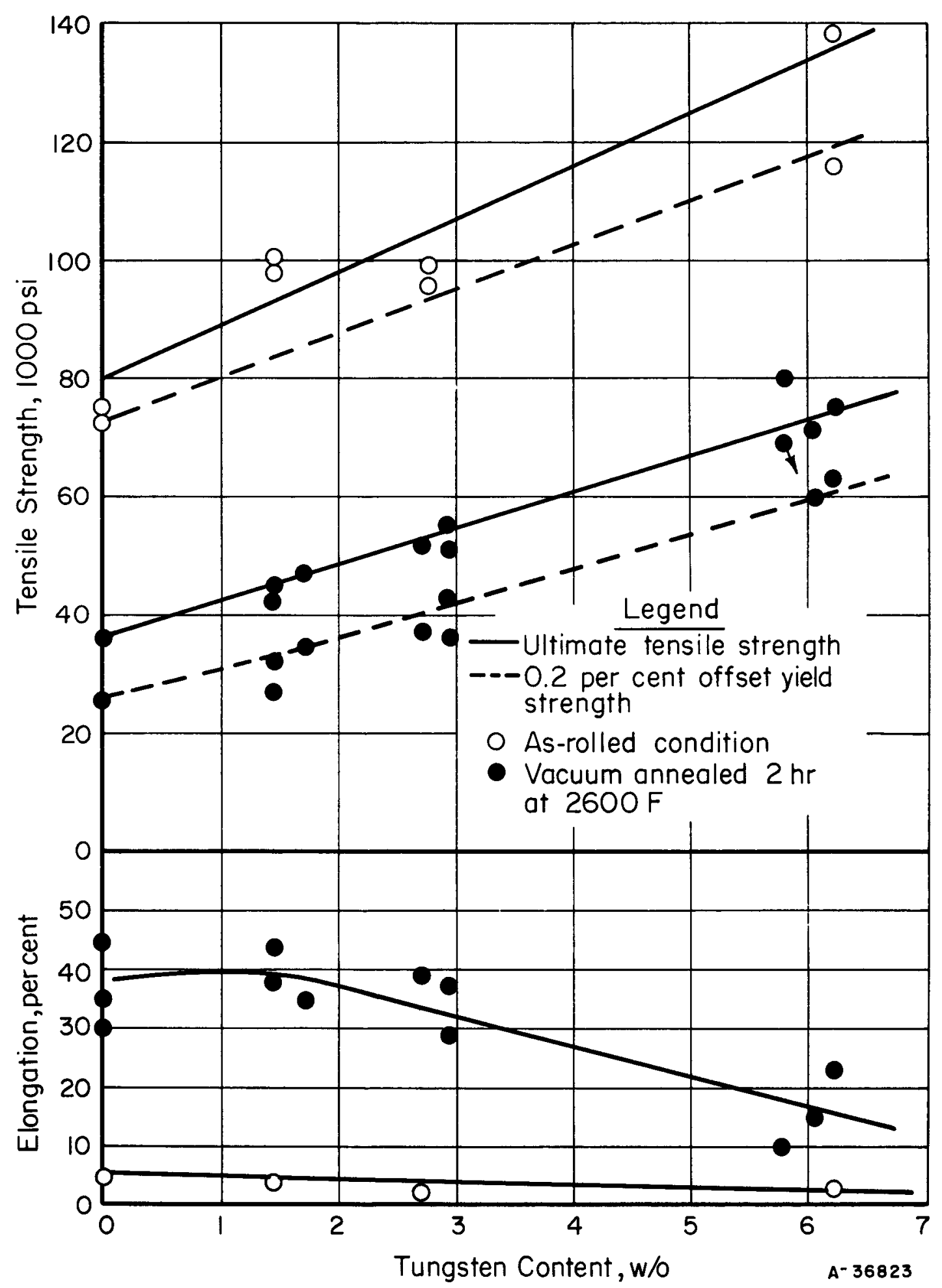

FIGURE 12. TENSILE PROPERTIES OF TANTALUM AND TANTALUM-TUNGSTEN ALLOYS 


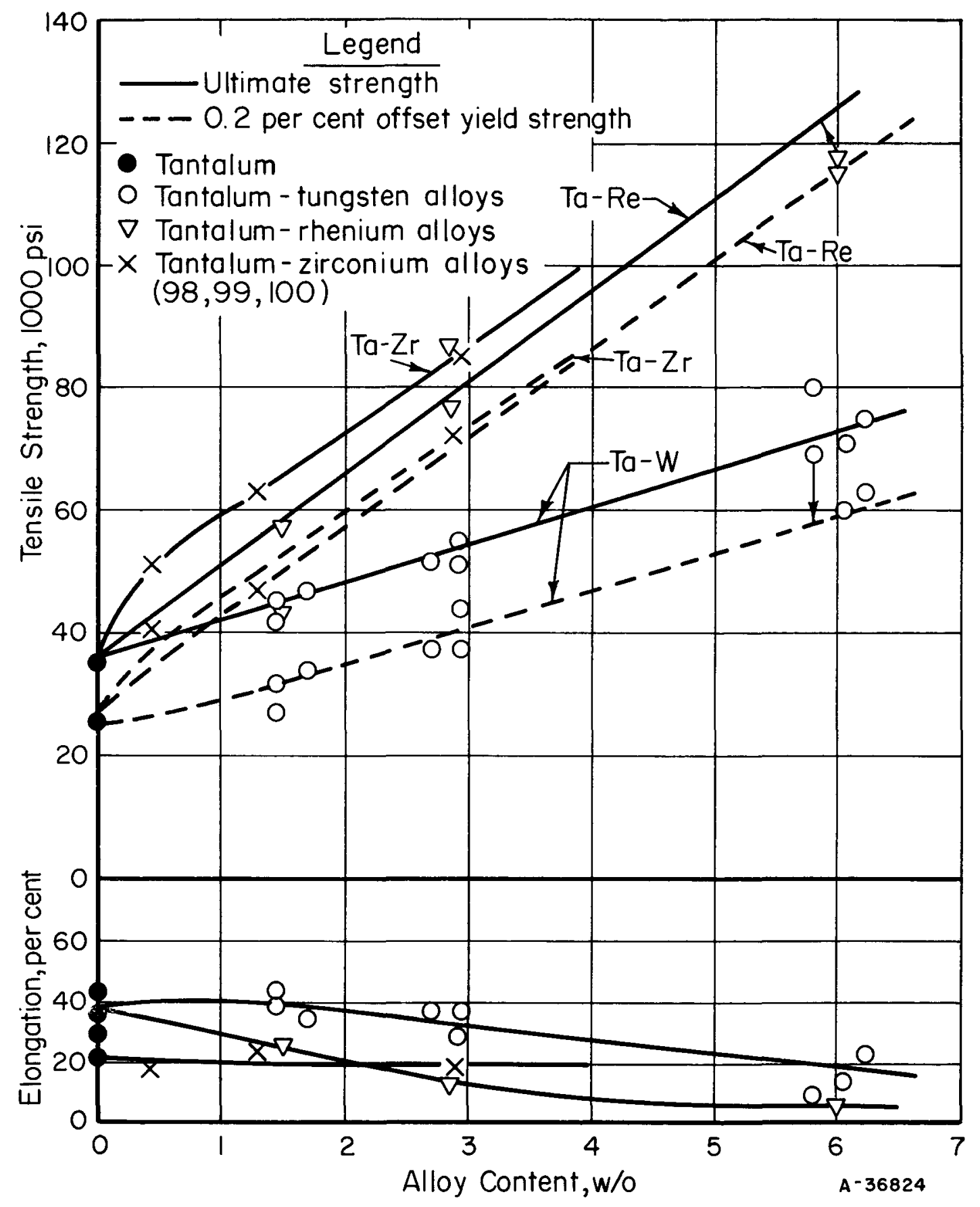

FIGURE 13. EFFECT OF RHENIUM, TUNGSTEN, AND ZIRCONIUM ADDITIONS ON THE TENSILE PROPERTIES OF ARC-MELTED TANTALUM

Specimens vacuum annealed as indicated in Table 15. 


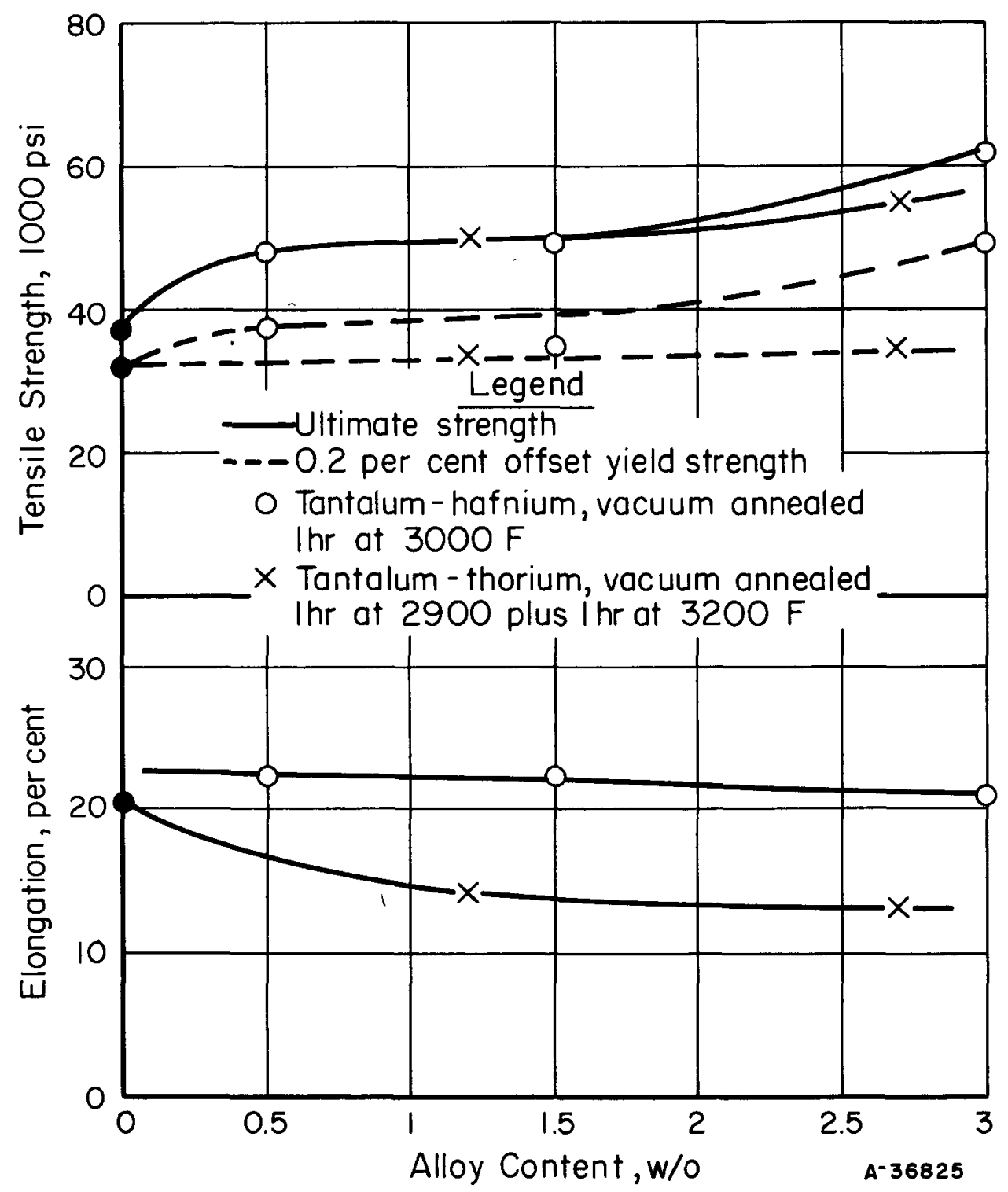

FIGURE 14. EFFECT OF HAFNIUM AND THORIUM ON THE TENSILE PROPERTIES OF ARC-MELTED TANTALUM 
Increasing additions of both hafnium and thorium produced stronger alloys with slightly lower ductilities. The higher strengths of two of the hafnium alloys, 49 and 50 , compared with those of two other hafnium alloys, 96 and 97 , were believed to have been caused by tungsten contamination (See Table 11) and the lower temperatures used to anneal the former alloys.

\section{Corrosion Testing}

Plutonium-alloy corrosion tests on the alloys prepared at Battelle were conducted at LASL. At present, not all of the materials have been evaluated. However, preliminary corrosion data were obtained on a few of the Battelle alloys and are encouraging. For example, alloys of the tantalum-rhenium and tantalum-tungsten systems have shown good corrosion resistance in polythermal (1382 to $1022 \mathrm{~F}$ ) tilting-furnace exposures. The tantalum-yttrium alloys also displayed good corrosion resistance, although all of the yttrium was apparently lost during arc melting. The tantalum- $0.025 \mathrm{w} / 0$ carbon alloy was severely attacked by the fuel. On the basis of the preliminary data, there is reason to believe that the resistance of tantalum to corrosion by plutonium-alloy fuels can be improved. A more complete and detailed report on the corrosion resistance of the Battelle alloys can be given by LASL, and is reserved for presentation in a LASL report.

\section{CONCLUSIONS}

The following conclusions were made regarding the use of tantalum and binary tantalum-base alloys as containe $r$ materials in LAMPRE applications:

(1) Preliminary plutonium-alloy corrosion tests indicate that good resistance to attack can be obtained by suitably alloying tantalum.

(2) Generally, high purity, which seems to be important in promoting resistance to plutonium-fuel alloy attack, can be maintained during arc melting.

(3) The hardness and tensile properties of tantalum can be increased significantly by moderate additions of alloying elements.

(4) In general, alloying additions had a refining effect on the grain size of tantalum. Also, the re was a marked tendency to increase the resistance to recrystallization.

(5) The oxygen content in tantalum apparently can be reduced by the addition of scavenging elements such a thorium, yttrium, and zirconium.

(6) In general arc-cast binary tantalum-base alloys containing additions not greater than $6 \mathrm{w} / \mathrm{o}$, can be fabricated to strip at room temperature. Notable exceptions are alloys of 0.5 to $1.0 \mathrm{w} / 0$ boron, greater than $0.025 \mathrm{w} / 0$ carbon, and 1.0 to $3.0 \mathrm{w} / 0$ silicon. 


\section{ACKNOW LEDGMENT}

The authors wish to express their appreciation to the Battelle staff members who contributed to the work, particularly Messrs. E. L. Foster and W. J. Hildebrand who provided helpful consultations, and Messrs. R. D. Tenaglia and R. R. Walker, who rendered technical assistance.

\section{REFERENCES}

(1) Private communication with LASL personnel.

(2) Hansen, M. , editor, Constitution of Binary Alloys, Second Edition, McGraw-Hill Book Co. , New York (1958), p 1226.

(3) Myers, R. H. , "Some Properties of Tantalum-Rich Alloys With Wolfram and Molybdenum", Metallurgia, $\underline{42}$, 3-9, (June, 1950).

(4) Stewart, J. C. , BMI, Unpublished Data.

(5) Perkins, R., "Tantalum Annealing and Degassing and Hardness Effects of Dissolved Gases", LA-2136 (September 30, 1957).

(6) Malter, L., and Langmuir, R. B., "Resistance, Emissivities, and Melting Points of Tantalum", Phys. Rev., 55, 743-47 (1939).

DCD:MEL:CJS:JGD:AMH/ajk 